Pâmela Tavares da Silva

Análise do perfil de metabólitos em Glycine max (L.) Merr submetida a diferentes níveis de radiação ultravioleta

Analysis of the profile of metabolites in Glycine $\max$ (L.) Merr submitted to different levels of ultraviolet radiation

São Paulo 2018 

Pâmela Tavares da Silva

\section{Análise do perfil de metabólitos em Glycine max (L.) Merr submetida a diferentes níveis de radiação ultravioleta}

\section{Metabolite profile of Glycine $\max$ (L.) Merr exposed to different levels of ultraviolet radiation}

Dissertação apresentada ao Instituto de Biociências da Universidade de São Paulo, para a obtenção de Título de Mestre em Ciências, na Área de Botânica.

Orientadora: Cláudia Maria Furlan

São Paulo

2018 


\section{Ficha Catalográfica}

Tavares-Silva, Pâmela

Análise do perfil de metabólitos em Glycine $\max$ (L.) Merr submetida a diferentes níveis de radiação ultravioleta

Número de páginas

Dissertação (Mestrado) - Instituto de Biociências da Universidade de São Paulo. Departamento de Botânica.

1. Palavra-Chave: flavonoides; isoflavonas; soja

I. Universidade de São Paulo. Instituto de Biociências. Departamento de Botânica.

Comissão Julgadora:

Prof(a). Dr(a). Prof(a). Dr(a).

Prof(a). Dr.(a).

Cláudia Maria Furlan 
À minha mãe que sempre me incentivou a ir atrás de meus sonhos e objetivos. E a minha cadelinha, Mary, companheira de todas as horas (In memorian). 

"Tu te tornas eternamente responsável por aquilo que cativa" Antoine de Saint-Exupéry, O Pequeno Príncipe 

Agradecer é preciso, pois não fazemos nada sozinhos nesta vida, e por causa disso sempre estarei disposta a agradecer, uma vez que até o que não é positivo serve para nos fazer melhores pessoas, além de trazer maturidade e conhecimentos.

Primeiramente, agradeço a Deus pelo do da vida e por ser meu porto seguro nos momentos de aflição e tristeza, e nos momentos de alegria.

Agradeço à minha orientadora, Cláudia, por aceitar me orientar, pela ajuda desde o início, quando estávamos apenas nos conhecendo. Obrigada por todo o ensinamento, conversas, advertências e tudo mais. Desculpa por não me fazer entender sempre. Uma palavra, Obrigada.

Agradeço a professora Dra. Silvia Ribeiro de Souza, pelo acolhimento quando fui fazer o experimento no Jardim Botânico de São Paulo. Agradeço a Mariana por toda a ajuda dada durante e depois do experimento, e pela amizade. Agradeço aos colegas Marcela, Débora, Gisele e Ricardo pela ajuda e conversas diversas.

Agradeço aos amigos e amigas dos laboratórios de Fitoquímica. À Gislaine (pelas conversas, conselhos e risos de sempre, uma boa amizade que o mestrado me concedeu), ao Paulo (por ser essa pessoa única, amável e amigo), à Tamara (amizade nova, mas que conservemos ela por muitos e muitos anos), à Dalila (mexicana que tanto me fez rir, que me ajudou muitas vezes, que nossa amizade permaneça). Aos amigos e amigas da sala 143, Fernanda Anselmo, Kátia, Fernanda Resende, Wilton e Richard por todas as conversas, ajudas e dicas.

Aos amigos e amigas da Anatomia, Fisiologia do Desenvolvimento Vegetal e Taxonomia, Leyde, Carlos Eduardo, Israel, Priscila, Frederico, Ricardo (Grilo), Bruno, Filipe, Rafael, Andressa.

Agradeço aos técnicos Rosário, Silvia, Tatiana que me deram suporte durante as análises do material de estudo quanto ao manuseio e entendimento de alguns equipamentos. Ao William, pelos momentos de descontração e pelo caloroso apelido dado por ele mesmo, "garota vortex". Às técnicas e técnico da Fitoquímica, Aline, Mourisa e Leandro. À Mourisa e Aline pelos momentos de risadas e descontração, suporte e ensinamentos em todas as minhas dúvidas.

Aos professores e professoras da Fitoquímica por todo o ensinamento, Maria Luíza, Antônio Salatino, Marcelo e Déborah.

Aos amigos e amigas que estão em Juiz de Fora, nada de nomes para não esquecer ninguém. Meu muito obrigada por todo o apoio nos momentos de alegrias e tristezas. Obrigada por sempre me fazer querida.

Aos amigos da "Casa da mãe Pâmela". À Priscila, pela amizade que vamos construindo, pelos momentos de descontração e pelo apoio. À Leyde, moça que conheço há pouco tempo, mas que é uma boa amiga, que ajuda a todos, e esquece de si mesmo, e que me incentiva quando preciso, e sei também que cultivamos uma amizade sincera, que me ajuda que perdure. À Andressa, ruivinha que mora no meu coração, obrigada pela amizade, companheirismo e cumplicidade. E ao Deni, amigo que conquistei há pouco tempo, mas que já me arrancou risadas intermináveis, que me motiva sempre e por ser tão querido. Obrigada por me acolher e me fazer feliz! Desculpa por qualquer coisa.

À minha irmã Paola, pela ilustração feita para minha dissertação, e à Michelle, pela ajuda na prancha final.

Agradeço à minha família por sempre se fazer presente em mensagens e ligações. Obrigada por serem meu porto seguro.

E por fim, à Capes pela concessão da bolsa, e aos laboratórios: Laboratório de Algas Marinhas, Fisiologia do Desenvolvimento Vegetal, Biologia de Sistemas (Molecular de Plantas) e Biologia Celular pelo suporte à realização de meu trabalho. 



\section{Lista de Tabela}

Tabela 1: Número de dias entre a germinação e o florescimento de soja das variedades CD202 e CD202RR mantidas nas diferentes exposições.

Tabela 2: Médias ( \pm desvio padrão) das massas foliares frescas e secas $(\mathrm{g})$ de Glicyne max para as câmaras Controle, UV- (ausência parcial de luz UV) e UV+ (acréscimo de luz UV) para cada estádio de desenvolvimento vegetativo analisado (V3, V4 e V5). .28

Tabela 3: Composição fenólica observada utilizando-se CLAE-DAD e CLAE-EM para os cultivares CD202 e CD202RR

Tabela 4: Constituintes da variedade CD202, em mg/g, para as câmaras Controle, UV(ausência parcial de luz UV) e UV+ (acréscimo de luz UV)

Tabela 5: :Constituintes da variedade de soja CD202RR, em mg/g, para as câmaras Controle, UV- (ausência parcial de luz UV) e UV+ (Acréscimo de luz UV). 36

Tabela 6: Comprimentos máximos de absorção do espectro UV-Visível das diferentes classes de flavonoides .45

Tabela 7: Porcentagem de variância explicada e esperada (estimada pelo teste de vara quebrada) na análise de PCA para os cinco primeiros eixos, utilizando 28 variáveis e 253 amostras analisadas .46

Tabela 8: Coeficientes de correlação entre as variáveis testadas e os eixos 1 e 2 . .46 



\section{Lista de Figuras}

Figura 1: Porcentagem da produção total por produto no Brasil.............................................4

Figura 2: Percentuais de matéria prima utilizada na produção de Biodiesel no Brasil................6

Figura 3: Mostra a atenuação das bandas de comprimento de onda UV-C, UV-B e UV-A na

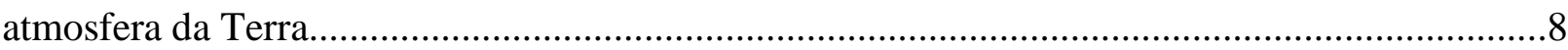

Figura 4: Esquema geral das vias de biossíntese do metabolismo vegetal secundário...............13

Figura 5: Espectro de transmissão $(200-1100 \mathrm{~nm})$ de diferentes materiais testados como filtros de radiação UV 19

Figura 6: Sistema de exposição das plântulas de soja a radiação luminosa................................19

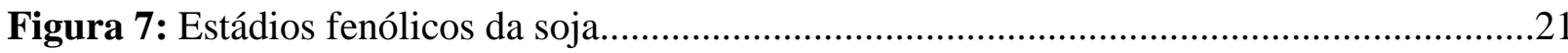

Figura 8: Esquema simplificado da metodologia de trabalho................................................23

Figura 9: A e B: Sojas em estádio V1. C: Sojas em estádio V4..............................................26

Figura 10: Cromatogramas no comprimento de onde $260 \mathrm{~nm}$, mostrando alguns dos contituintes marjoritários da soja

Figura 11: Espectros de absorção UV-Vis $(200-660 \mathrm{~nm})$ das substâncias encontradas para os cultivares CD202 e CD202RR

Figura 12: Conteúdos de substâncias fenólicas agrupadas nas classes derivados cinâmicos, flavonoides e isoflavonoides ao longo do desenvolvimento de Glicine max cultivares CD202 (A, B e C) e CD202RR (D, E e F) nos diferentes tratamentos: Controle, UV+ e UV.38

Figura 13: Conteúdos de substâncias fenólicas agrupadas nas classes de derivados cinâmicos, flavonoides e isoflavonoides de Glicine max cultivares CD202 (A, B e C) e CD202RR (D, E e F) nas diferentes câmaras. V3, V4 e V5 = estádios de desenvolvimento vegetativo. 40

Figura 14: Heatmap das variações para os dois cultivares do estudo para as substâncias analisadas em CLAE-DAD.

Figura 15: Estruturas básicas de algumas classes de flavonoides .44

Figura 16: Análise de componente principal (PCA) usando os 28 variáveis e 253 amostras.....47

Figura 17: Via de síntese dos compostos fenólicos. Heat map correspondem a figura 14 para o cultivar CD202 .50

Figura 18: Via de síntese dos compostos fenólicos. Heat map correspondem a figura 14 para o cultivar CD202RR. 



\section{Resumo}

Fabaceae é a terceira maior família botânica, apresentando grande importância ecológica, ornamental e econômica. Por sua grande diversidade de espécies está dividida em seis subfamílias Caesalpinioideae, Cercidoideae, Detarioideae, Dialioideae, Duparquetioideae e Papilionoideae. Papilionoideae é considerada um grupo monofilético e nesta está inserida Glycine $\max ($ L.) Merr., espécie de importância econômica alimentícia (grãos, farelo, óleo) e medicinal. A soja tem seu centro de origem na China, sendo que a soja moderna foi modificada por cruzamentos entre duas espécies selvagens, por cientistas ainda na antiga China. É considerada um alimento completo, pois contém proteínas, gorduras, óleos, aminoácidos essenciais e metabólitos secundários, tais como isoflavonas e outras substâncias fenólicas, importantes antioxidantes naturais. A liberação do plantio da soja se deu com a Lei 11.105 de 24 de março de 2005, levando a um aumento exponencial de sua produção no país. Seu consumo ocorre em todo o mundo, e sua produção aumenta a cada ano, pois também vem sendo utilizada como fonte para a produção de biocombustível. Atualmente, sabemos que a poluição atmosférica e outras atividades humanas contribuem para o aumento de poluentes na atmosfera e consequente impacto na camada de ozônio. A radiação ultravioleta é dividida em três: ultravioleta A (315 a $400 \mathrm{~nm})$, ultravioleta B $(280$ a $315 \mathrm{~nm})$ e ultravioleta C (200 e $280 \mathrm{~nm})$. Por conta disso, estudos que visam avaliar como a radiação ultravioleta pode interferir no metabolismo vegetal podem contribuir para o conhecimento mais aprofundado sobre como espécies cultivadas são afetadas por esse fator de estresse. Os metabólitos especiais são importantes estratégias químicas usadas pelas plantas na sua defesa contra fatores de estresse biótico ou abiótico. Em particular, as substâncias fenólicas como os flavonoides e isoflavonas são importantes metabólitos envolvidos nos mecanismos de defesa vegetal associados à fotoproteção. Este projeto teve por objetivo contribuir com conhecimentos quanto aos efeitos da radiação ultravioleta sobre a produção de metabólitos fenólicos durante o desenvolvimento vegetativo de dois cultivares de soja CD202RR e CD202, quando submetidos a três tratamentos com diferentes incidências de radiação ultravioleta (UV): 1. Ausência de radiação UV (UV-), 2. Alta incidência de radiação UV (UV+) e 3. Incidência natural de radiação UV solar (Controle). A hipótese deste estudo partiu do pressuposto que substâncias fenólicas são reconhecidos metabólitos vegetais com propriedades de absorção de luz nos comprimentos de onda do espectro UV-Visível, sendo assim, aumentariam em conteúdo em resposta a alta intensidade de radiação UV. Foram feitas análises por CLAE-DAD e CLAE-MS das substâncias fenólicas em folhas de G. max em três estádios vegetativos (V3, V4 e V5). As sementes de soja foram germinadas dentro das câmaras e 10 plantas foram coletadas por estádio, em cada câmara e em 3 repetições de experimentos (setembro de 2016 a março 2017). Foi verificado que o tratamento UV+ resultou em menores massas foliares quando comparado ao Controle e UV-. Há também diferença nas alturas das plantas de soja e danos nas folhas produzidos pela maior incidência de radiação UV. Foram identificados 28 constituintes, sendo 13 derivados do ácido cinâmico, 9 derivados dos flavonoides campferol e apigenina e 6 isoflavonas derivadas de genisteína e daidzeína. Quanto aos conteúdos fenólicos, pode-se observar que há um aumento da quantidade de isoflavonas na câmara UV+ em relação ao Controle para ambos os cultivares. Para os derivados cinâmicos e os flavonóis encontrados, observa-se um decréscimo em relação ao Controle para grande parte desses constituintes. Diminuição no conteúdo de flavonóis e aumento de isoflavonas pode ser devido a um possível desvio da via de produção dos flavonoides, uma vez que naringenina é o precursor para a síntese de ambas as classes. Além disso, isoflavonas apresentam espectro de absorção UV-Vis com banda máxima no comprimento de onda entre 260-280 nm, o que pode resultar em maior fotoproteção para plantas expostas a maiores intensidades de radiação UV. 



\section{Abstract}

Fabaceae is the third largest botanical family, with great ecological, ornamental and economic importance. For its great diversity of species, the family is divided into six sub-families Caesalpinioideae, Cercidoideae, Detarioideae, Dialioideae, Duparquetioideae and Papilionoideae. Papilionoideae is a monophyletic group comprising Glycine max (L.) Merr., an important economic species for food (grains, bran, oil) and medicine. Glycine has its center of origin in China, and modern soybean has been modified by crosses between two wild species, by scientists still in ancient China. It is considered a complete food because it contains proteins, fats, oils, essential amino acids and secondary metabolites, such as isoflavones and other phenolic substances, important natural antioxidants. The liberation of soybean culture occurred in Brazil after the 11,105 law of March 24, 2005, leading to an exponential increase of its production in the country. Its consumption occurs all over the world, and its production increases every year, since it is also used as a source for the production of biofuel. We now know that atmospheric pollution and other human activities contribute to the increase of pollutants in the atmosphere and a consequent impact on the ozone layer. Ultraviolet radiation (UV) is divided into three: ultraviolet A (315 at $400 \mathrm{~nm}$ ), ultraviolet B (280 to $315 \mathrm{~nm}$ ), and ultraviolet C (200 and $280 \mathrm{~nm}$ ). Because of this, studies aiming to evaluate how ultraviolet radiation can interfere on plant metabolism may contribute to better understand of how cultivated species are affected by this stress factor. Special metabolites are important chemical strategies used to plant defense against biotic or abiotic stress factors. In particular, phenolic substances such as flavonoids and isoflavones are important metabolites involved in the plant defense mechanisms associated to photoprotection. The objective of this project was to contribute with knowledge about the effects of ultraviolet radiation on the production of phenolic metabolites during the vegetative development of two soybean cultivars CD202RR and CD202, when exposed to three UV treatments: 1. Absence of UV radiation (UV-), 2. High incidence of UV radiation ( $U V+$ ), and 3. Natural incidence of solar UV radiation (Control). The hypothesis of this study was based on the assumption that phenolic substances are recognized plant metabolites with properties of light absorption in the wavelengths of the UV-visible spectrum and thus could increase in content in response to high intensity of UV radiation. Analyzes were performed using HPLC-DAD and HPLC-MS of leaves of G. max at three vegetative stages (V3, V4 and V5). Soybean seeds were germinated within the chambers and 10 plants were collected per stage, in each chamber and in 3 experiment replicates (September of 2016 to March of 2017). It was observed that UV+ treatment resulted in smaller leaf biomass when compared to Control and UV-. There were also differences in soybean heights and leaf damage produced by the higher incidence of UV radiation. A total of 28 constituents were identified, of which 13 were cinnamic acid derivatives, 9 kaempferol and apigenin derivatives, and 6 genistein and daidzein derivatives (isoflavones). Was observed an increase in the contents of isoflavones in the UV+ comparing to Control, for both cultivars. Cinnamic acid derivatives and flavonoids showed decreased contents in relation to the Control. Decreases in flavonoid content together with increases in isoflavones might be explain by a possible flavonoid pathway deviation, since naringenin is precursor of both flavonoid classes. Isoflavones show UV-Vis absorption spectra with maximum absorption between $260-280 \mathrm{~nm}$, which might result in higher capacity for UV photoprotection. 



\section{Índice}

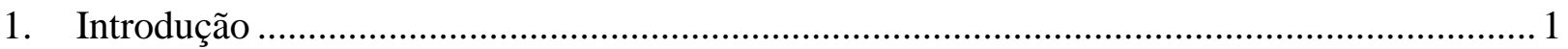

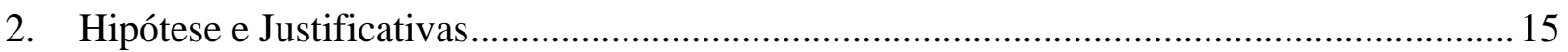

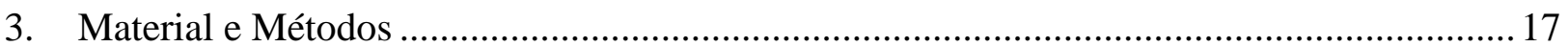

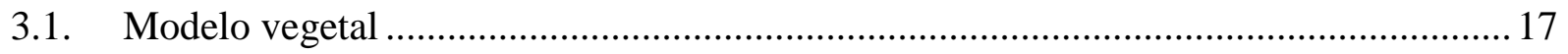

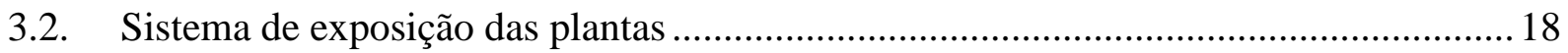

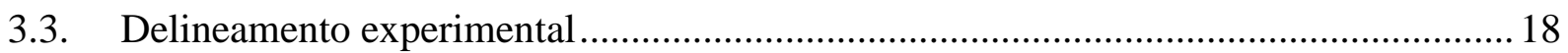

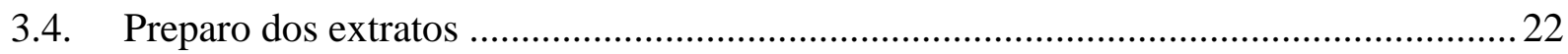

3.5. Composição química ……………………………………………………………...2 22

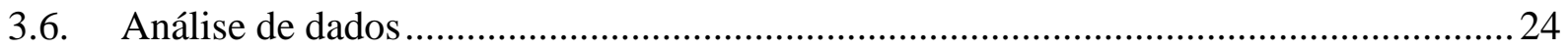

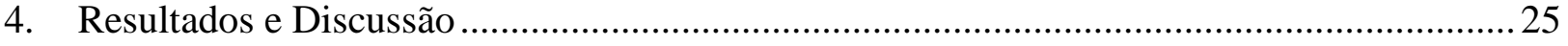

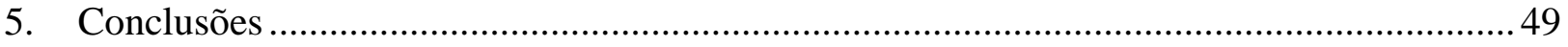

6. Referências Bibliográficas ............................................................................................. 53 



\section{Introdução}

Fabaceae tem importância econômica, ecológica, ornamental e medicinal, além de ser a terceira maior família botânica no mundo, ficando atrás de Asteraceae e Orchidaceae em número de espécies (YAHARA et al., 2013). Sob o ponto de vista econômico, é a segunda mais importante, ficando atrás de Poaceae (YAHARA et al., 2013). Devido a sua grande diversidade de espécies, Fabaceae compreende seis sub-famílias, sendo elas Caesalpinioideae, Cercidoideae, Detarioideae, Dialioideae, Duparquetioideae e Papilionoideae (LPWG, 2017), abrangendo cerca de 19.500 espécies e 770 gêneros. A monofilia do grupo está sustentada por dados moleculares, mas a monofilia de Caesalpinioideae ainda é incerta devido a novas descobertas moleculares (LPWG, 2017).

A subfamília Papilionoideae tem suporte pelas análises de filogenia molecular para ser considera um grupo monofilético e é também a maior das subfamílias, com 28 tribos, 478 gêneros e cerca de 13.800 espécies no mundo (LEWIS et al. 2005). No grupo Milletoide (TOZZI, 2016) esta inserida Glycine $\max$ (L.) Merrill, popularmente conhecida por soja, uma importante espécie agronômica (YAHARA et al., 2013).

Desde de sua origem até os dias de hoje, a agricultura vem sofrendo muitas modificações, onde deixou de ser artesanal e manual (FULLER et al., 2010) e passou a ser mecanizada; as culturas foram domesticadas, e assim estimuladas a produzirem os melhores grãos ou frutos. Algumas espécies cultivadas passaram por diversas modificações, melhoradas ou transformadas por engenharia genética para aumento de produção e resistência a interferências bióticas ou abióticas (DALL'AGNOL et al., 2008).

Estima-se que cerca de 2.500 espécies vegetais foram domesticadas com êxito, dentre elas estão as grandes culturas que temos atualmente, como milho, arroz, feijão, cítricos, batata, algodão, soja, dentre tantas outras. Outras plantas alimentícias, consumidas no dia-a-dia, são cultivadas em seus locais de origem e exportadas, pois dificilmente se adaptam a qualquer ambiente, e ainda estão passando pelo processo de domesticação (LEVETIN \& MCMAHON, 2011).

Em um trabalho realiado por XU \& GAI (2003), utilizando AFLP (Polimorfismo de comprimento de fragmentos amplificados), observou-se que as variedades de soja cultivadas atualmente apresentam características estruturais e químicas diferentes das apresentadas pelas espécies ancestrais que lhes deram origem, uma vez que ocorreram cruzamentos naturais entre 
espécies selvagens (soja silvestre e soja silvestre cultivada) que foram domesticadas e melhoradas por cientistas da antiga China (XU \& GAI, 2003).

Estima-se que a espécie ancestral da soja, antes do processo de domesticação, era uma planta rasteira e habitava a costa leste da Ásia, principalmente a China e, por isso, acredita-se que o centro de diversidade genética da soja seja a China. Entretanto, a espécie também tem distribuição e ocorrência em regiões adjacentes como o Japão, Coréia (XU \& GAI, 2003; PEREIRA NETO, 2004) e o leste da Rússia (XU \& GAI, 2003).

XU \& GAI (2003), em seu trabalho, avaliaram a diversidade genética de espécies selvagens relacionadas a soja moderna. Os autores analisaram por AFLP 21 variedades de soja selvagem e 27 cultivares de soja de ocorrência no território chinês. Com a utilização do método citado, verificaram que as espécies de soja selvagem apresentam maior variabilidade genética quando comparadas às espécies de soja cultivadas, corroborando o dado que a variabilidade genética é reduzida pela domesticação. Para o território, foi verificado que as variedades analisadas poderiam ser agrupadas em dois conjuntos de dados representados pelas espécies selvagens e as cultivadas. Observaram, ainda, que a variabilidade genética apresenta um padrão que reflete a origem geográfica dessas espécies e, que há cultivares de soja que não se enquadram nos grupos verificados, uma vez que seus genótipos não se encontram diferenciados o sufuciente e, por isso, os autores sugerem que ainda ocorrem cruzamentos naturais entre essas variedades.

A soja é conhecida como um grão sagrado pelos povos do Oriente e é intensamente explorada na dieta Oriental (PEREIRA NETO, 2004; DALL'AGNOL et al., 2008). Mesmo tendo origem em clima temperado, possui ampla adaptação aos climas subtropicas e tropicais (YAHARA et al., 2013). Entretanto, o Ocidente ignorou seu cultivo até a segunda década do século XX, quando os Estados Unidos (EUA) começaram a sua exploração comercial, inicialmente como uma planta forrageira e depois para a exploração do grão.

No Brasil, os primeiros materiais genéticos de soja foram introduzidos e testados na Bahia, em 1882. Por ter pouca adaptabilidade à baixa latitude, o material não se desenvolveu nessa região. Novos materiais foram levados à São Paulo e região Sul do Brasil, onde se conseguiu êxito na produção de feno e grãos. Assim como ocorreu nos EUA, as variedades de soja introduzidas no Brasil foram estudadas apenas sob o ponto de vista de características interessantes para uma planta forrageira e, somente mais tarde, essa espécie se tornaria importante na produção de grãos e óleos vegetais (PEREIRA NETO, 2004). 
Os organismos geneticamente modificados (OGMs), são assim denominados devido a uma modificação do DNA via aplicação da biotecnologia. As modificações visam, em grande parte, uma maior produção de sementes (uso de terreno menor e amadurecimento em menor tempo), resistência a pragas, herbicidadas, e/ou condições climáticas (DE LAS FUENTES LACAVEX et al., 2016), tolerância à seca e maior rendimento quando em cultivo sob seca (MANAVALAN \& NGUYEN, 2017). Além disso, com o uso de uma área menor para plantio, tem-se o consumo de água reduzido, menor consumo de inseticidas e menor emissão de $\mathrm{CO}_{2}$ (o uso de óleo diesel na manutenção da cultura é reduzido) (COLLI, 2011).

Com a promulgação da Lei 11.105 de 24 de março de 2005, esta passa a regulamentar pelos incisos II, IV e V do $§ 1^{\circ}$ do art. 225 da Constituição Federal (BRASIL, LEI 11.105, 2005) o estabelecimento de normas de segurança e mecanismos de fiscalização de atividades que envolvam organismos geneticamente modificados (OGMs) e seus derivados, criando o Conselho Nacional de Biossegurança (CNBS) e reestruturando a Comissão Técnica Nacional de Biossegurança (CTNBio), a qual dispõe sobre a Política Nacional de Biossegurança (PNB) (COLLI, 2011). A promulgação dessa lei em 2005 revogou a Lei no 8.974, de 5 de janeiro de 1995, e a Medida Provisória n⿳o 2.191-9, de 23 de agosto de 2001, assim como os artigos 5ㅜㅜ 6º $7^{\circ}, 8^{\circ}, 9^{\circ}, 10$ e 16 da Lei $n^{\circ} 10.814$, de 15 de dezembro de 2003, além de outras providências (BRASIL, LEI 11.105, 2005). Com a Lei 11.105 em vigor, as atividades com OGMs, especialmente os transgênicos, passam a ser liberadas e, com isso, o plantio, consumo e exportação de variedades transgênicas passam a aumentar exponencialmente no país (CONAB, 2018).

A produção agrícola brasileira é umas das principais bases da economia do país desde os primórdios da colonização até a atualidade, evoluindo das extensas monoculturas para a diversificação da produção. A agricultura é uma atividade que faz parte do setor primário onde a terra é cultivada e colhida para subsistência, exportação ou comércio. Inicialmente produtora de cana-de-açúcar, passando pelo café, a agricultura brasileira apresenta-se como uma das maiores exportadoras do mundo em diversas espécies de cereais, frutos, grãos, entre outros (PEREIRA NETO, 2004). Com isso, na figura 1 podemos observar a porcentagem de produção total por produto plantado no Brasil em levantamento realizado pela Companhia Nacional de Abastecimento (CONAB) em 2016. 


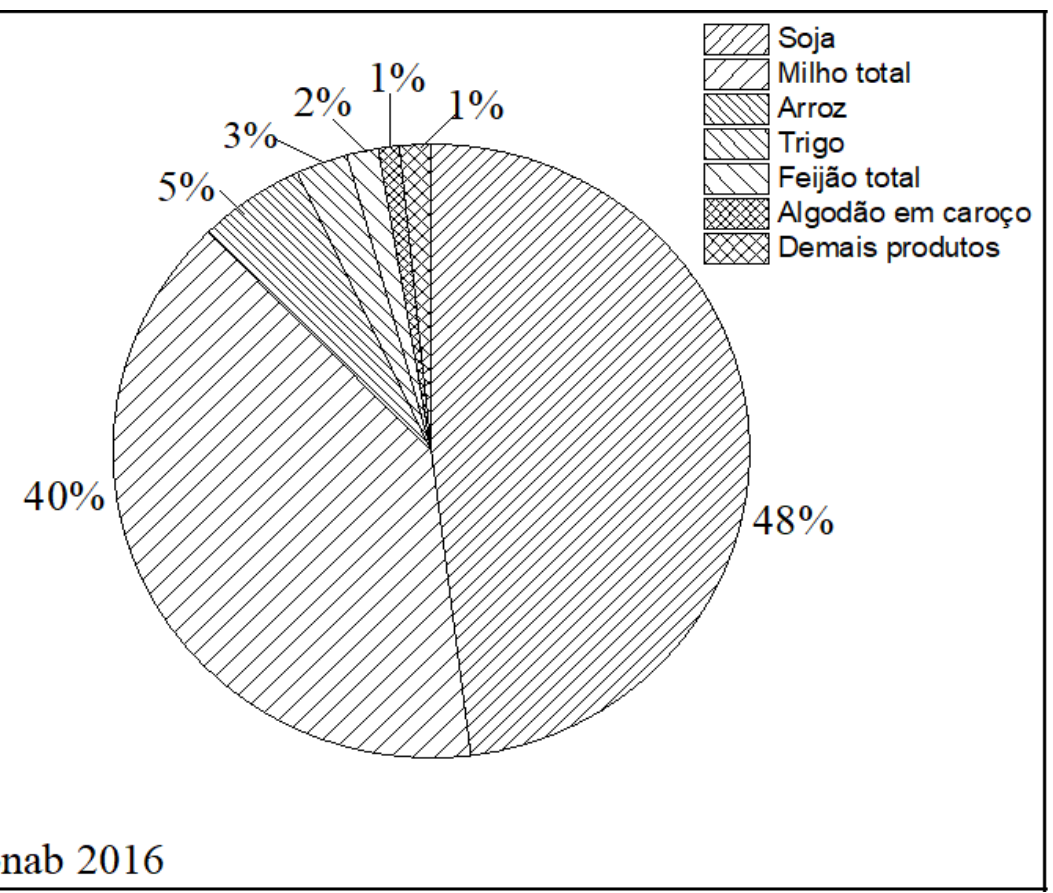

Figura 1: Porcentagem da produção total por produto no Brasil. Acompanhamento da safra brasileira de grãos. Quinto levantamento - 02/2016. (CONAB, 2016)

Segundo relatório divulgado pelo Departamento de Agricultura Americano (USDA), há uma estimativa de 334,81 milhões de grãos de soja para a safra 2017/2018. Para soja, os maiores produtores mundialmente são EUA, correspondendo a 35,70\% da produção mundial, seguidos pelo Brasil $(34,35 \%)$ e pela Argentina (11,95\%), onde juntos somam $82 \%$ da safra mundial de soja (AMAZONAS, 2018).

O Brasil possui uma área estimada em 61 milhões de hectares plantados com diferentes culturas, e tem-se uma produção estimada em 229,5 milhões de toneladas de grãos para a safra 2017/2018. A mais expressiva é a cultura da soja, que possui uma área estimada de 35,1 milhões de hectares para a safra 2017/2018, onde o plantio aumenta ano a ano, pois as condições climáticas e a disponibilidade tecnológica contribuem para isso. Hoje, tem-se uma produção estimada em 114,97 milhões de toneladas de grãos para a safra 2017/2018, consumidos tanto no mercado interno quanto para a exportação, seja na forma de complexos (soja em grão, farelo e/ou óleo) ou individual (ABIOVE, 2018). Atualmente, a China é o maior importador de produtos derivados de soja (CONAB, 2018).

Segundo AKITHA DEVI \& GIRIDHAR (2015), globalmente, a soja é uma leguminosa economicamente importante devido ao seu elevado teor de proteínas (40\%), de óleo (17-20\%) (DALL'AGNOL et al., 2008; MARZULLO, 2007) e de fitoquímicos benéficos, como isoflavonas, outras substâncias fenólicas, saponinas, inibidores de tripsina (SAKTHIVELU et al., 2008), goitrogênios e oligossacarídeos (LIENER, 1994). Tem-se também que o interesse do 
consumidor em seus produtos processados tem aumentado em vista da sua utilização em alimentos para humanos e para animais, além de ser considerada nutracêutica (AL-TAWAHA et al, 2007; AKITHA DEVI et al, 2009), ser utilizada pela indústria farmacêutica como bioativo (ANJUM et al., 2017), e fazer parte da lista de fitoterápicos da Rede Pública de Saúde Brasileira (RENISUS) para prescrições para mulheres em climatério (RENISUS, 2018).

Além da importância alimentícia e farmacêutica acima citadas, a soja também apresenta um importante papel na mudança da matriz enérgica brasileira. Hoje em dia, há um forte incentivo pela busca de fontes renováveis de energia, pois a utilização das fontes convencionais de origem fóssil, contribui para a poluição do meio ambiente, além de se caracterizarem como recursos findáveis (ou não renováveis). Os derivados de petróleo e carvão alimentam grandes setores da economia atual e a utilização destes combustíveis lança na atmosfera mais de seis bilhões de toneladas de dióxido de carbono por ano (HOLANDA, 2004).

O óleo diesel é o derivado do petróleo mais utilizado no Brasil e movimenta grande quantia de dinheiro com a sua importação. Hoje tem-se uma pressão para a diminuição de seu uso, uma vez que é um combustível de origem não renovável e emite grande quantidade de poluentes para atmosfera. No Brasil, já temos que metade da produção energética é proveniente de energia renovável (GARCILASSO et al., 2015). Tendo em vista o potencial agrícola brasileiro e os condicionantes ambientais mundiais, tornou-se oportuno discutir sobre a produção de fontes alternativas de energia para esse derivado do petróleo (DOMINGUES \& DAMASCENO, 2008).

O biodiesel produzido no Brasil pode ter por matéria-prima o óleo de soja, gorduras de animais, óleo de algodão, óleo usado em frituras e outras fontes. Para o ano de 2017, o óleo de soja foi o mais utilizado na produção do Biodiesel, tendo um consumo de $3.007 .545 \mathrm{~m}^{3}$, corespondendo a aproximandamente 70\% (Figura 2A). Para o ano de 2018, até março, o óleo de soja se encontra entre o mais utilizado, com consumo de $686.640 \mathrm{~m}^{3}$, o que corresponde a aproximadamente 68\% (Figura 2B). A produção de biodiesel em 2017 foi de $4.291 .294 \mathrm{~m}^{3}$ (ABIOVE, 2018). Com a Lei $\mathrm{n}^{\circ}$. 11.097 de Janeiro de 2005 passa a ser obrigatório a introdução do Biodiesel na matriz energética Brasileira em 7\% para o percentual mínimo no diesel fóssil (GARCILASSO et al., 2015). Todavia, outras alterações foram feitas na lei ao longo dos anos, e em março de 2016, uma nova modificação ocorre, passando a valer a Lei $n^{\circ} 13.263$ que altera a quantidade de percentuais obrigatórios ao diesel, estes passam a ser de $9 \%$ para o ano de 2018 e 10\% em 2019 (BRASIL, LEI 13.263, 2016). 


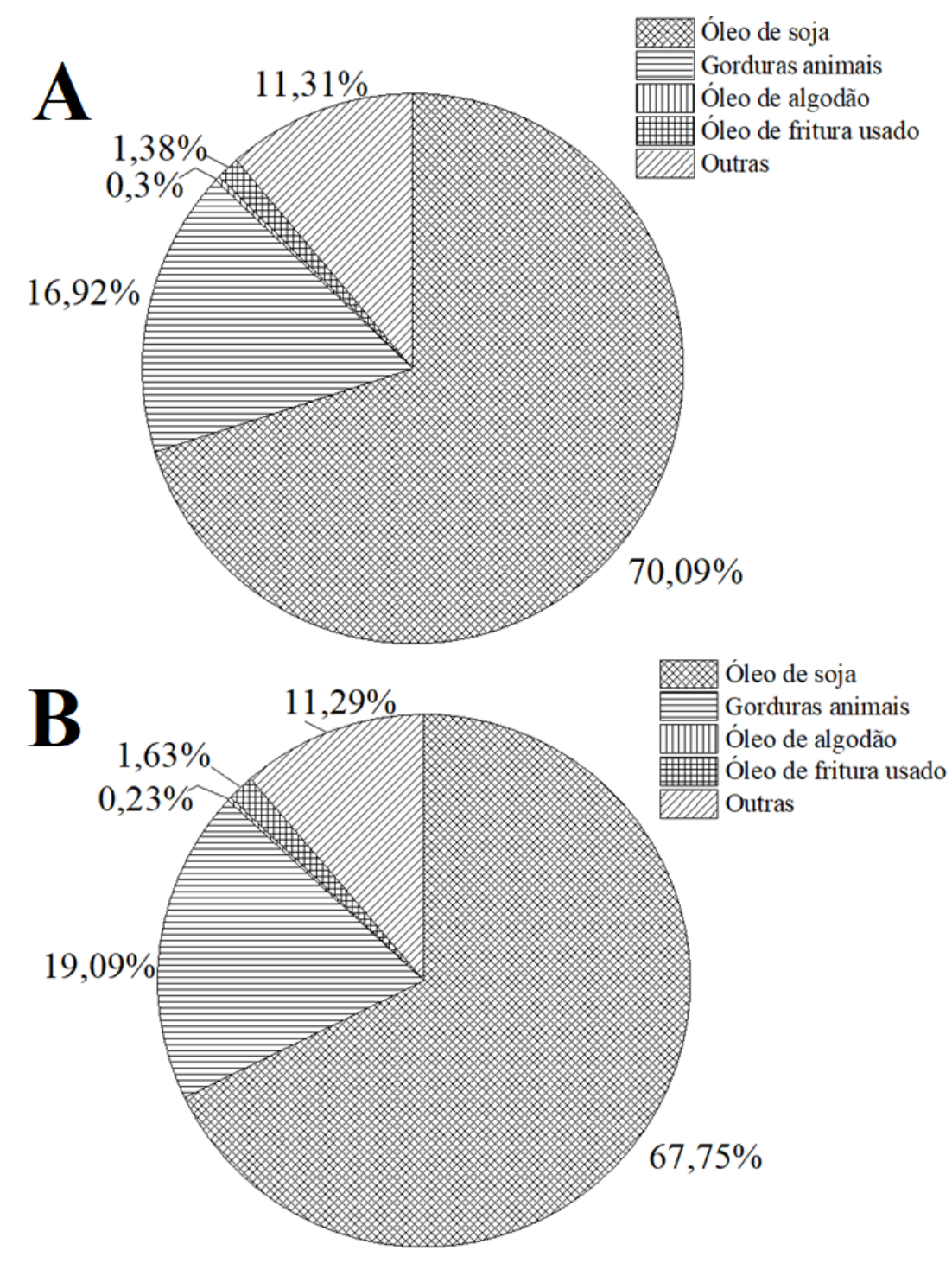

Figura 2: Percentuais de matéria prima utilizada na produção de Biodiesel no Brasil. A: Produção de Biodiesel para o ano de 2017. B: Produção de Biodiesel para o primeiro trimestre de 2018. ABIOVE. Brasil, Biodiesel. Produção de Biodiesel por matéria prima. 2018.

A semente de soja produz de 17 a $20 \%$ de óleo de sua massa fresca (DALL'AGNOL et al., 2008; MARZULLO, 2007). Todavia, o óleo de soja é utilizado pela população mundial no preparo de alimentos e rações animais sendo assim economicamente viável do ponto de vista da comercialização. Outros produtos derivados da soja incluem óleos, farinha, sabão, cosméticos, resinas, solventes e agora, como alternativa para produção de biocombustíveis (DOMINGUES \& DAMASCENO, 2008). Dessa forma, as sementes de soja vem sendo utilizadas em grande escala na indústria, seja para a alimentação humana, para a produção de margarinas e sabões, seja para uso como aditivos de tintas e vernizes e/ou como aditivo ao óleo diesel. 
O óleo da semente de soja tem por constituinte marjoritário o ácido linoleico, o que resulta em um óleo considerado não ideal como lubrificante. A grande proporção de ácido linoleico, devido às ligações duplas em sua estrutura, diminui a viscosidade do óleo, isto quando em bombas e injetores, pode levar ao desgaste e assim, diminui a vida útil do componente mecânico que fizer uso do biodiesel. Entretanto, o uso do óleo de soja ainda é a alternativa mais viável para a utilzação no biodiesel, por ser economicamente viável (DOMINGUES \& DAMASCENO, 2008).

O uso do óleo de soja adicionado ao óleo diesel se mostra importante, uma vez que há uma redução de $78 \%$ de emissão de gás cabônico líquido durante a queima, considerando a absorção pelas plantas (HOLANDA, 2004). Além disso, há redução de $90 \%$ de emissão de fumaça e óxido de enxofre, sendo também uma opção para a possível falta futura dos cobustíveis fósseis (DOMINGUES \& DAMASCENO, 2008).

O histórico de uso de combustíveis fósseis unido a outras atividades antrópicas esta relacionado aos altos níveis atuais de poluentes. A diminuição do ozônio estratosférico tem aumentado a preocupação com a implicação ecológica do aumento da radiação ultravioleta (UV) sobre a produção agrícola e os ecossistemas naturais (PAUL, 2000; KATARIA \& GURUPRASAD, 2012a; KATARIA et al., 2014b; TOPCU et al., 2015). A radiação ultravioleta (200-400 nm) é prejudicial para os organismos vivos devido aos danos ao DNA que pode causar e pela produção de espécies reativas de oxigênio (EROs), também relacionadas ao surgimento de várias doenças e ao envelhecimento (SOUZA et al., 2005). No caso da agricultura, a alta incidência de radiação UV pode comprometer o rendimento futuro da colheita e a qualidade da mesma, devido às implicações fisiológicas, morfológicas e bioquímicas (KATARIA \& GURUPRASAD, 2012a).

Em trabalhos como de SOUZA et al. (2005), KATARIA et al.,, (2014a); WILLIAMSON et al., (2014), JANSEN (2017) entre outros, encontramos que as radiações ultravioletas estão divididas em: ultravioleta A (UV-A), ou longas, entre os comprimentos de onda de 315 a $400 \mathrm{~nm}$; ultravioleta B (UV-B), ou medianas, de 280 a $315 \mathrm{~nm}$ e ultravioleta C (UV-C), ou ondas curtas, entre 200 e 280 nm (Figura 3). 


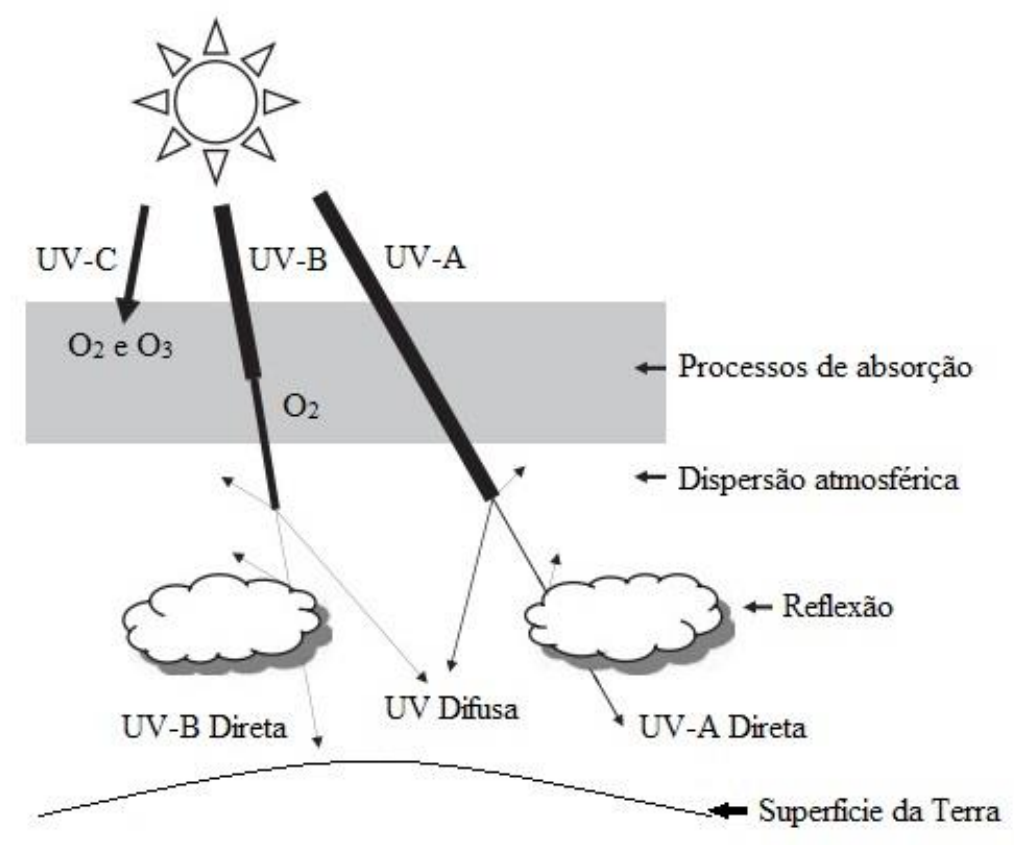

Figura 3: Esquema da atenuação das bandas de comprimento de onda UV-C, UV-B e UV-A na atmosfera da Terra. Segundo JANSEN (2017), comprimentos de onda UV menores que $242 \mathrm{~nm}$ são efetivamente absorvidos pelo $\mathrm{O}_{2}$, enquanto comprimentos de onda menores que $290 \mathrm{~nm}$ são absorvidos pelo $\mathrm{O}_{2}$ e $\mathrm{O}_{3}$. Quanto aos processos de absorção, comprimentos de onda acima de $290 \mathrm{~nm}$ não são absorvidos, estando presentes na biosfera. A dispersão e a reflexão alteram ainda mais o espectro do UV solar e, como resultado, uma proporção considerável dos fótons UV atinge a superfície da Terra como radiação difusa. (Adaptado de JANSEN, 2017).

A radiação UV-A, passa por completo pela camada de ozônio, sem haver nenhum filtro, esta é estudada para saber seu efeito nos vegetais, onde pode estimular ou inibir o acúmulo de biomassa e na morfologia das plantas (VERDAGUER et al., 2017). Já a radiação UV-B, uma parte fica retida na camada de ozônio e a outra parte é liberada na superficie terrestre. Está é responsável por causar alguns maleficios à saúde animal (LÖFGREN, 2016) e vegetal, como dano ao DNA, produção de espécies reativas de oxigênio, entre outros (PAUL, 2000). Entretanto, concentrações ideais são necessárias para ativar o metabolismo vegetal, sendo, portanto, importante fisiologicamente (BALLOTTARI et al., 2013; SURGET et al., 2015; VIDOVIĆ et al., 2015). A radiação UV-C é bloqueada pela camada de ozônio, não ultrapassando a mesma na maioria dos casos, entretanto quando passa, pode causar danos ao organismo, além de ser considerada potencialmente mais prejudicial (WILLIAMSON et al., 2014). Portanto, a radiação ultravioleta absorvida ao longo do dia dos organismos e em excesso pode vir a causar danos que podem ser irrevissíveis à saúde desses organismos (ANJUM et al., 2017), logo conhecer a dinâmica de exposição da planta à radiação UV ao durante o dia pode ser 
de grande valia para mensurar os possíveis efeitos que a exposição à radiação UV pode ocasionar aos vegetais (JANSEN, 2017).

Nos vegetais, os compostos fenólicos, como o ácido cafeico e seus derivados, flavonoides, cumarinas, entre outras classes, são responsáveis pela absorção e fotoproteção frente às radiações UV-A, UV-B e UV-C. Essas substâncias fotoprotetoras apresentam espectros de absorção UV-Visivel (UV-Vis) com picos máximos próximos entre os comprimentos de onda da radicão UV, absorvendo totalmente a radiação UV-B (SURGET et al., 2015). Além disso, essas substâncias também apresentam propriedades antioxidantes, representando um importante recurso na remoção/inativação das espécies reativas de oxigênio (EROs), produzidas em maior quantidade frente à ação de fatores de estresse (BALLOTTARI et al., 2013; VIDOVIĆ et al., 2015a).

De forma generalizada, as células vegetais são sensíveis à radiação ionizante. Esta, ao entrar em contato com a célula pode ter o efeito de excitar (fraca interação), inibir e/ou dissociar (interação forte) moléculas. Por exemplo, quando a radiação atinge as moléculas de água que se encontram no interior das células, esta pode induzir a formação de espécies reativas de oxigênio, deflagrando um estresse oxidativo que pode ter efeitos tanto no metabolismo primário quanto secundário (KOVÁCS \& KERESZTES, 2002).

No ambiente natural, a radiação UV-A é responsável pela resposta de síntese de flavonoides na planta (VIDOVIĆ et al., 2015a). O aumento da incidência de radiação UV-B, assim como grande intensidade de radiação luminosa são frequentemente reportados como causadores de estresse à planta (HOLLÓSY, 2002). Grandes intensidades luminosas podem exceder a capacidade fotossintética e, com isso, produzir grande quantidade de EROs, podendo gerar dano aos constituintes celulares. Além disso, em plantas sob estresse luminoso, foi observada indução da atividade protetora antioxidante, com aumento na produção de substâncias fenólicas (VIDOVIĆ et al., 2015a). Já a radiação UV-C, quando em grande quantidade, é danosa ao organismo (HOLLÓSY, 2002) e outras classes de substâncias fenólicas podem ser alocadas em resposta a esse estresse, como o observado para Linum usitatisimum L. (Flax), que apresentou aumento nos conteúdos de lignóides quando sob estresse por UV-C (ANJUM et al., 2017).

Plantas expostas à radiação ultravioleta tendem a apresentar mudanças bioquímicas, como a produção de substâncias fenólicas aumentada e alterações nas propriedades ópticas das folhas - proteção do aparato fotossintético e diminuição de lesões ao DNA (TOPCU et al., 2015; ZAVALA et al., 2015). Efeitos no crescimento, danos aos fotossistemas 
(fotomorfogênico) e desenvolvimento da planta também foram relatados (PAUL, 2000), embora também haja o relato de que doses normais não causam danos em algumas espécies (ALLEN et al. 1998). Com isso, quando há um grande acúmulo de substâncias fenólicas na folha, este tende a reduzir os efeitos adversos da radiação UV-B (KALING et al., 2015; BANO et al., 2017).

Os flavonoides, importante classe de substâncias fenólicas, têm a capacidade de absorver e dissipar a radiação luminosa sem causar danos subsequentes. Isso acontece porque os flavonoides tem região de absorção do espectro luminoso que varia de 240-400 nm, tendo assim a capacidade de absorver em todos os comprimentos de onda ultravioleta (UV-A, UV-B e UVC). Muitas espécies vegetais podem responder negativamente à exposição à radiação ultravioleta. Alguns dos efeitos já relatados são: diminuição da taxa de crescimento, redução da superfície foliar, redução da absorção da luz visível, entre outros. Solanum lycopersicum L. variedade Pusa ruby (BANO et al., 2017), Arabidopsis thaliana (L.) Heynh. (BOEGER \& POULSON, 2006) e Brassica oleraceae L. (TOPCU et al., 2015), mostraram efeitos negativos similares quando submetidas à radiação UV.

BANO et al., (2017) em seu trabalho utilizaram sementes de Solanum lycopersicum variedade Pusa ruby por ser uma planta comercial e cultivada em todo o mundo. Solanum é conhecido por apresentar a produção do ácido benzóico e este tem potencial alelopático (VALDEZ SEPÚLVEDA et al, 2015), e quando presente no solo, tem atividade autotóxica em raízes (ASAO et al., 2003). Foram utilizadas duas concetrações de ácido benzóico no trabalho, 0,5 nmM e 1,0 mM em seis tratamentos: Controle, UVA, Ácido benzóico 1 (0,5 mM), Ácido benzóico 2 (1,0 mM), Ácido benzóico 1+UV e Ácido benzóico 2+UV. O experimento foi feito com plantas de 15 dias e o tratamento inicial era feito com as diferentes concetrações de ácido benzóico seguido pela exposição por 60 minutos à radiação UV-B, por três dias consecutivos. Na combinação de ácido benzóico 1,0 mM com radiação UV-B, as mudas apresentam uma diminuição mais acentuada no crescimento radicular, parte aérea, biomassa seca e teores de pigmentos, proteínas e açúcares. Além disso, quando em análises separadas, onde se observava o incremento de UV-B ou o efeito do ácido benzóico, houve aumento na produção de caratenoides e na atividade antioxidante, o que os autores sugerem como uma forma a proteção ao aparato fotossintético e ao material genético.

A soja é considerada um alimento rico em aminoácidos essenciais que não são produzidos pelos humanos, sendo também associada às isoflavonas, por estas serem benéficas à saúde. Todavia, alimentos como feijão, alfafa, ervilhas e amendoim também sintetizam essa classe de metabólito (VISNEVSCHI-NECRASOV et al., 2015). Muitos isoflavonoides já foram 
identificados, e a grande diversidade e complexidade estrutural são causadas por reações de hidroxilação e alquilação, variando o nível de oxidação do anel heterocíclico, ou formando anéis heterocíclicos adicionais (DEWICK, 2009).

Os isoflavonoides formam uma subclasse bastante distinta dos flavonoides, onde a diferença estrutural se dá pela migração do anel aromático, vindo da via do chiquimato, para o carbono adjacente do heterociclo (DEWICK, 2009). Este rearranjo é raro na natureza, e embora os flavonoides sejam encontrados em todo o domínio vegetal, os isoflavonoides são mais restritos, sendo bastante caractrísticos de Fabaceae (DEWICK, 2009; ZAVALA et al., 2015), estando presentes em Biserrula sp., Phaseolus sp., Glycine sp., Lotus sp., Ornithopus sp. e Scorpiurus sp., por exemplo.

Os isoflavonoides desempenham papel importante na saúde humana, pois se assemelham ao estrogênio produzido pelas mulheres, e este durante o climatério pode ser substituído por alimentos contendo soja. Em um estudo com mulheres orientais chinesas em relação às mulheres ocidentais, o consumo de soja pode retardar o aparecimento de câncer de colo de útero e mama no grupo asiático (LEE et al., 2008; KIM et al., 2012; HE \& CHEN, 2013; SHURTLEFF et al., 2014). Outros tabalhos mostram o uso de soja no tratamento de câncer de estômago e próstata (HE \& CHEN, 2013; SHURTLEFF et al., 2014), na redução do colesterol (SLAVIN et al., 2009), entre outros benefícios para a saúde.

A radiação UV-B pode ter relevância ecológica por causar efeitos na produção de metabólitos fenólicos e na capacidade de oxi-redução, pois interfere na indução de genes para a síntese de enzimas que darão sequência à biossíntese das substâncias fenólicas, reconhecidas como antioxidantes (VIDOVIĆ et al., 2015). Pode, ainda, induzir respostas morfológicas, fisiológicas (fotossíntese) e moleculares (dano em macromoléculas como DNA, RNA e proteínas) (INOSTROZA-BLANCHETEAU et al., 2014). Como exemplo, a radiação UV-B em excesso geralmente causa alterações morfológicas, como redução do crescimento e do tamanho das folhas, e aumento da ramificação ou perfilhamento e número de folhas, devido a sua influência na estrutura dos tilacoides dos fotossistemas (KOVACS \& KERESZTES, 2002). Essas alterações favorecem a criação de um microclima favorável à infecção por fungos e bactérias (MANNING \& TIEDEMANN, 1995; PAUL, 2000). Em estudo desenvolvido com Arabidopsis thaliana foi demonstrado que essa espécie é sensível à radiação UV-B, tendo um menor desenvolvimento foliar (diminuindo sua biomassa) e maior produção de substâncias fenólicas, a qual os autores associaram ao papel de minimizar os efeitos negativos da radiação no desenvolvimento foliar (BOEGER \& POULSON, 2006). 
De forma didática, podemos dizer que o metabolismo primário é responsável pela produção de protoplasto (todo o conteúdo celular exceto parede celular) e produção de energia para o corpo vegetal, ou seja, está envolvido na síntese de carboidratos, proteínas, nucleotídeos e lipídios (BUCHANAN, 2015). As rotas bioquimicas envolvidas no metabolismo primário são as mesmas para todos os organismos vivos, como animais, bactérias, fungos, plantas e outros organismos, levando à síntese de substâncias universais aos organismos vivos (DEWICK, 2009; TAIZ \& ZIEGER, 2009).

O metabolismo secundário, ou especial, não esta relacionado aos processos de produção de energia e/ou constituição do protoplasto, levando à síntese de substâncias que não estão distribuídas por todos os organismos de forma ubíqua, expressando assim a individualidade de famílias, gêneros e, até mesmo, espécies. Essas substâncias secundárias ou especiais estão relacionados à defesa química contra micro-organismos (fungos, bactérias e infecções virais), herbivoria, alelopatia, assim como na atração de polinizadores e dispersores dos frutos, e sinalização para diferentes processos fisiológicos (DEWICK, 2009). Alem disso, tambem atuam como defesas químicas frente a estresses ambientais, como presença de poluentes, seca, radiação UV, entre outros. Por conta disso possuem grande diversidade estrutural, demonstrando assim a grande plasticidade de adaptação frente aos fatores bióticos e abióticos (DEWICK, 2009).

Os metabólitos secundários são muito diversos, mais de 50 mil já foram identificados em espécies de angiospermas, e são sintetizados em diferentes compartimentos celulares, por quatro vias de biossíntese: via do Ácido Malônico, do Ácido Mevalônico (MEV), do Metileritritol Fosfato (MEP) e do Ácido Chiquímico. Através dessas vias são formados os três principais grupos de metabólitos secundários: terpenos, substâncias fenólicas e substâncias nitrogenadas (Figura 4). Essas classes, acima citadas, são derivadas de blocos construtores oriundos do metabolismo primário, demonstrando assim, a conexão entre as vias de síntese do metabolismo vegetal (DEWICK, 2009).

Os metabólitos secundários possuem funções ecológicas importantes nos vegetais, além de serem importantes para a prática da agricultura, uma vez que a produção destes pode tornar a planta inapta ao consumo humano (ZAVALA et al., 2015). Hoje se tem o cultivo de plantas selecionadas artificialmente para que estas não venham a produzir metabólitos secundários indesejados para o consumo, entretanto, isso pode tornar tais culturas mais susceptíveis a doenças e ao ataque de herbívoros (TAIZ \& ZIEGER, 2009). 


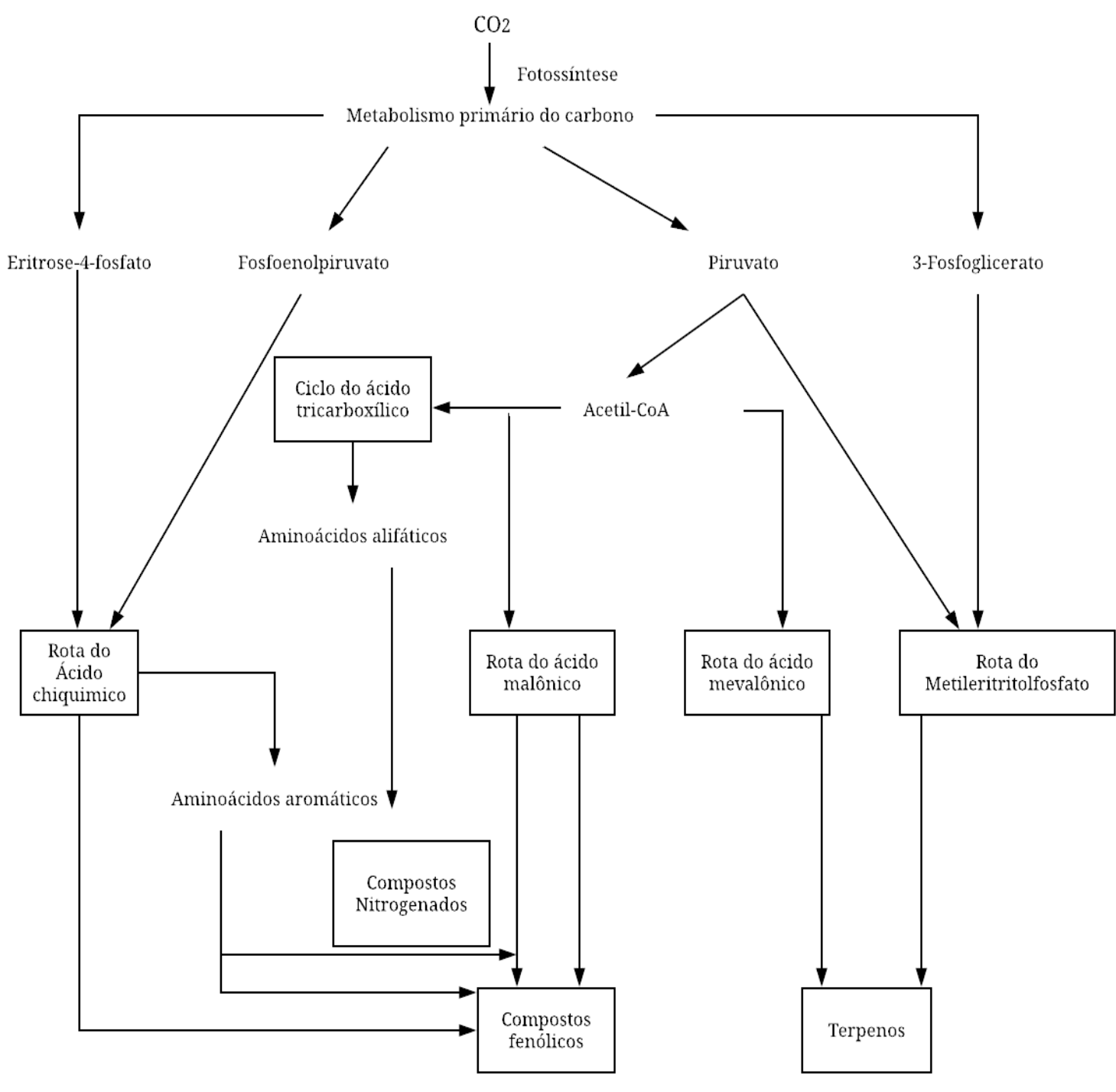

Metabolismo Secundário do Carbono

Figura 4. Esquema geral das vias de biossíntese do metabolismo vegetal secundário. Retirado de TAIZ \& ZIEGER, 2009. 



\section{Hipótese e Justificativas}

A soja é muito estudada quanto aos seus grãos mas as folhas têm poucos estudos relacionados a composição química (KOTI et al., 2007), uma vez que o interesse para a indústria é a obtenção de um grão de qualidade e rico em proteínas, óleos, substâncias fenólicas, como as isoflavonas (AKITHA DEVI \& GIRIDHAR, 2015). As isoflavonas são importantes por serem utilizadas em tratamentos de saúde, como câncer de mama e próstata (LEE et al., 2008; HE \& CHEN, 2013), sendo especialmente utilizadas por mulheres em climatério (RENISUS). As substâncias frequentemente descritas como constituintes de sementes de soja são as substâncias fenólicas como as flavanonas, flavonóis (quercetina-3-O-rutinosideo; luteolina-7-Oglucosideo; campferol-3-O-glucosideo; campferol-3- $O$-rutinosideo; luteolina-4'-O-glucosideo), ácidos fenólicos (ácido 5-O-cafeoilquinico; ácido cafeico; ácido p-cumárico; ácido ferúlico; ácido cinâmico), isoflavonas (daidzina, genistina, daidzeína, genisteína, glicitina, gliciteína) (DUKE et al., 2003; CUNHA, 2013; SILVA et al., 2013), isoflavonas aciladas (6"-Oacetildaidzina, 6"-O-acetilglicitina e 6"-O-acetilgenistina; 6"-O-malonildaidzina, 6" $O$ malonilglicitina e 6"-O-malonilgenistina) (CUNHA, 2013). Também já foram descritos triterpenos (betulina) e esteróis (estigmasterol; campesterol; $\beta$-sitosterol) (SILVA et al., 2013).

Para as folhas já foram descritos os flavonóis campferol-3-O-ramnosil-glucosídeo; campferol glucosídeo; campferol-3-O-diramnosil-galactosídeo; campferol-3-O-digalactosídeo; campferol-3-O-ramnosil-galactosídeo; campferol-3-O-rutinosídeo; e isoflavonas como daidzina e malonil-daidzina, genistina e 6"'-O-malonilgenistina, daidzeína e genesteína (HO et al., 2002). Entretanto, estudos utilizando folhas de soja como modelo para o estudo dos efeitos da radiação UV são escassos.

Nossa hipótese inicial é a que Glycine max quando exposta às diferentes radiações UV apresentará alterações na produção de metabólitos secundários, principalmente aumento nos conteúdos de substâncias fenólicas (reconhecidas por absorverem radiação nessa faixa do espectro luminoso) na exposição com elevada radiação UV. Trabalhos como de ZAVALA et al., (2015) e TOPCU et al., (2015) nos auxiliaram a reforçar nossa hipótese, uma vez que relatam acúmulo de substâncias fenólicas quando a planta é exposta a diferentes intensidades de radiação UV. Nesses estudos, a exposição prolongada à radiação alterou a quantidade de substâncias fenólicas totais e flavonoides, além de ter promovido uma queda na quantidade de carotenoides e clorofila, e diminuição da atividade antioxidante da planta. Por se tratar de uma espécie importante na alimentação e na matriz energética brasileira, a realocação de recursos para a produção de substâncias de proteção pode refletir, como consequência, em modificações 
morfológicas, redução de biomassa e alterações na síntese de metabolitos primários como açúcares solúveis e lipídeos, levando a diminuição da produtividade e qualidade dos grãos.

Desta forma, o objetivo geral deste estudo foi contribuir com conhecimentos quanto aos efeitos da radiação ultravioleta sobre a produção de metabólitos fenólicos durante o desenvolvimento vegetativo da soja. Especificamente verificamos o desenvolvimento de dois cultivares de Glycine max (CD202 e CD202RR) para responder à pergunta:

- Plantas de soja obtidas a partir da germinação sob diferentes intensidades de radiação UV apresentarão alteração na síntese de metabólitos fenólicos? 


\section{Material e Métodos}

\subsection{Modelo vegetal}

Os cultivares Glycine max CD202 e CD202RR foram cedidos pela Coodetec (Cooperativa Central de Pesquisa Agrícola Ltda), que integrava a APASEM - Associação Paranaense dos Produtores de Sementes e Mudas, todavia adquirida pela Dow AgroScience ${ }^{\circledR}$. Segundo a Coodetec (2016), esses cultivares possuem as seguintes características para a região de São Paulo:

- Possuem ciclo total médio de 130 dias e ciclo vegetativo médio de 46 dias;

- Possuem tamanho médio de $72 \mathrm{~cm}$, podendo ser suscetíveis ao acamamento;

- Possuem flor branca, pubescência cinza e hilo marrom claro;

- São tolerantes aos nematoides de galhas Meloidogyne incognita (Kofoid \& White) Chitwood e Meloidogyne paranaensis, e suscetíveis ao Meloidogyne javanica (Chitwood);

- Para os nematoides que causam lesões radiculares são tolerantes ao Rotylenchulus reniformis Linford \& Oliveira;

- São resistentes ao cancro da haste e mancha "Olho de Rã”, sendo suscetíveis ao Oídio da soja (para todas as doenças mencionadas, pode haver variação de acordo com a variabilidade do patógeno ou surgimento de novas espécies).

Além disso, todas as características mencionadas para soja podem variar com as interações com o ambiente, onde há necessidade de uma alta fertilidade do solo, sendo estas tolerantes a solos ácidos; possuem eficiência na incorporação de adubos; necessitam de espaço de $45 \mathrm{~cm}$ radiais para a semeadura; possuem época para semeadura preferencial de 25 de outubro até dia 05 de dezembro; e possuem época de semeadura tolerada de 20 de outubro até o dia 10 de dezembro (“COODETEC”, 2018).

A variedade CD202RR tem incorporado ao seu DNA, o gene Roundoup Ready® (RR), essa modificação gênica confere a propriedade de resistência ao herbicida Roundoup®, tendo assim, a propriedade de tolerância ao glifosato. Esta modificação, quando aplicado o herbicida, permite que a planta não seja morta, enquanto que plantas daninhas e alguns insetos morram (EMBRAPA, 2004). 


\subsection{Sistema de exposição das plantas}

Três tipos de câmaras foram utilizadas nas exposições para promover ambientes com intensidades controladas de radiação UV. As câmaras estão instaladas no Instituto de Botânica de São Paulo e são operadas e monitoradas pela equipe da Dra. Silvia Ribeiro de Souza.

As exposições Controle, UV+ e UV- foram construídas com a utilização de filtros e lâmpadas. Para a exposição UV-, a câmara foi construída usando um filtro de acrílico para o bloqueio da radiação UV, além de permitir a passagem de boa parte da radiação visível e infravermelho, ambas indispensáveis para o desenvolvimento adequado das plântulas. As câmaras UV+ e controle foram construídas utilizando teflon, material que permite a passagem da radiação ultravioleta, visível e infravermelho de ocorrência natural na cidade de São Paulo. A câmara UV+ continha uma lâmpada TL 40W/12 RS SLV (fabricante: Phillips), sendo esta fluorescente de emissão de $40 \mathrm{~W}$ na região do espectro eletromagnético entre 290 e $315 \mathrm{~nm}$, proporcionando o aumento da radiação UV-B nesta câmara. O espectro de transmissão dos materiais utilizados na construção das câmaras pode ser observado na figura 5, justificando-se, assim, o uso do acrílico como bloqueador para as radiações UV-B e UV-C.

As câmaras foram montadas em bases de metal que deram suporte a molduras nas quais os filtros foram fixados. Estas bases de metal deixaram as plântulas a uma distância de $70 \mathrm{~cm}$ do nível do solo. Cada moldura apresentava a dimensão de $120 \mathrm{~cm}$ de comprimento por $50 \mathrm{~cm}$ de altura e uma espessura de dois centímetros. Os filtros de acrílico (para exposição UV-) e de Teflon (para exposição UV+ e Controle) apresentavam a espessura de 2,0 mm e 0,5 mm, respectivamente. $\mathrm{O}$ teto de cada câmara foi constituído de duas molduras acopladas entre si por peças metálicas (manoplas), as quais permitiam ajustar o ângulo entre as molduras, sendo este fixado em torno de 15 graus. Esta angulação entre as molduras garantiu o escoamento da água da chuva. Na câmara UV+ foi instalada, na junção entre as molduras, um calha de metal para a colocação da lâmpada, responsável pelo acréscimo de radiação UV. Esta calha, além de facilitar a instalação da lâmpada, é revestida internamente por material refletor que permitiu um uso mais eficiente da radiação emitida pela lâmpada ao direcionar a luz para a região de exposição (Figura 6).

\subsection{Delineamento experimental}

As sementes de Glycine max CD202 e CD202RR foram germinadas em vasos de plástico de volume total de 0,5 L, contendo substrato vegetal Tropstrato HT Hortaliças® (Viva Verde), vermiculita grossa (Brasil Minérios) e água, na proporção 3:1:1. O suprimento hidríco, cerca de $100 \mathrm{~mL}$, por vaso, foi realizado por rega em dias alternados. 


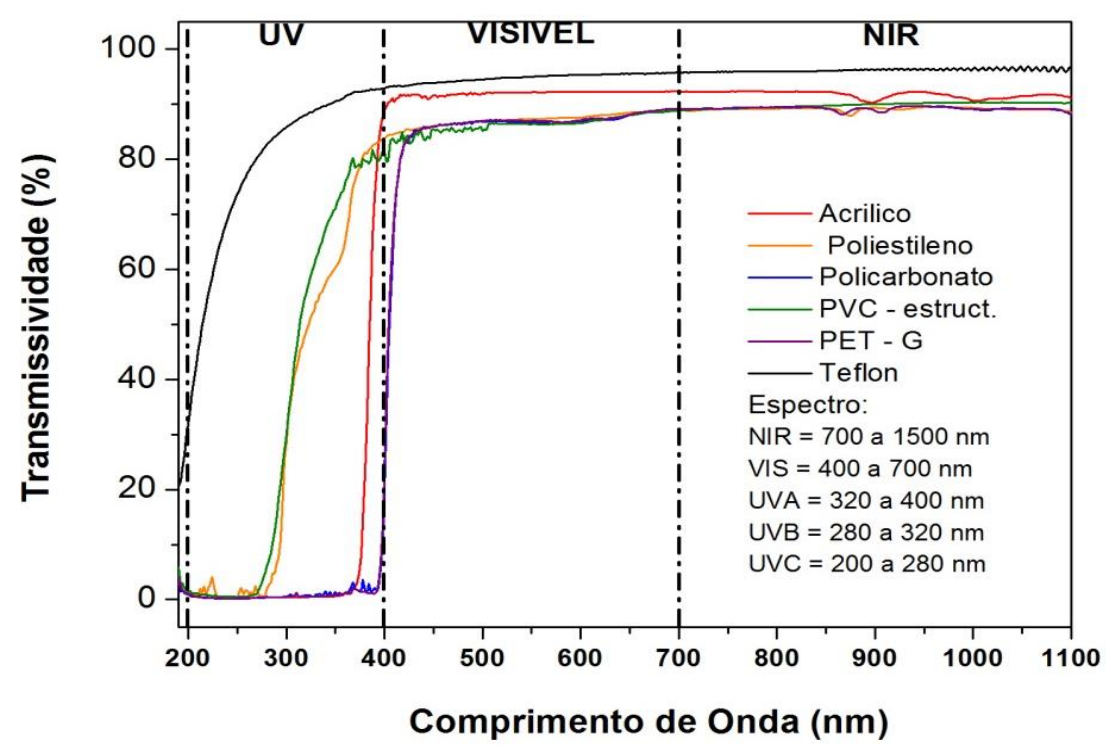

Figura 5. Espectro de transmissão $(200-1100 \mathrm{~nm})$ de diferentes materiais testados como filtros de radiação UV (dados fornecidos pela Dra Silvia Ribeiro de Souza).

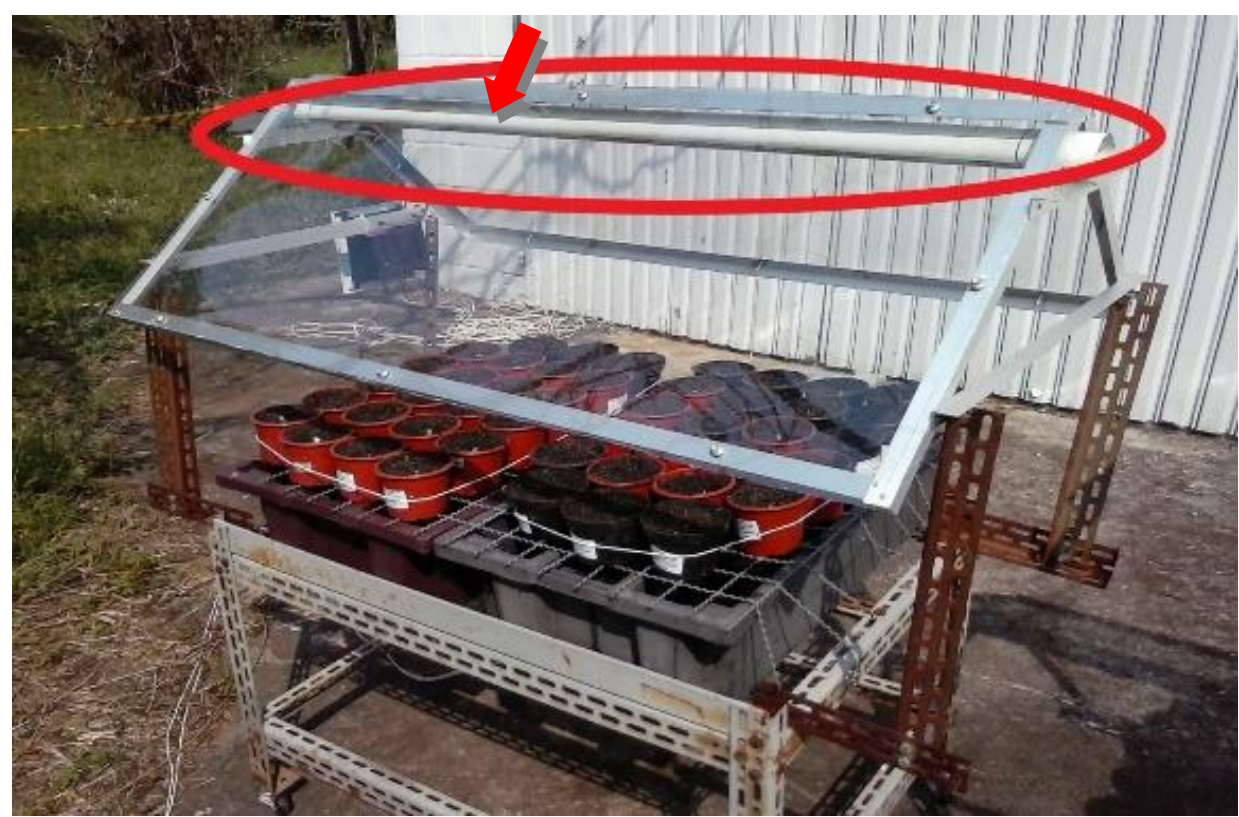

Figura 6: Sistema de exposição das plântulas de soja a radiação luminosa. Câmara UV+, notar a lâmpada fluorescente instalada (seta). 
Todas as sementes foram germinadas no interior das câmaras, as sementes do tratamento com radiação UV receberam radiação desde o plantio, totalizando cerca de 60 plântulas (30 CD202 e 30 CD202RR) por exposição. A exposição a luz UV foi realizada durante duas horas diárias, iniciando às 10 horas e findamdo às 12 horas. Para estes cultivares, aguardava-se em torno de uma semana para que elas atinginssem cada estádio, logo, por exemplo, para chegar no estádio V3, aguardamos um mês, no estádio V4, mais uma semana e no estádio V5, outra semana.

Ao longo do período de exposição, foram coletadas folhas nos estádios vegetativos V3, V4 e V5 (Figura 7). Os estádios vegetativos obedeceram a classificação utilizada por FEHR \& CAVINESS (1977) pela EMBRAPA (2013).

A diferenciação entre estádio vegetatitvo e estádio reprodutivo é feita observando os nós foliares. O primeiro nó é dispensado, porque é o nó cotiledonar. Os estádios vegetativos são divididos em estádio vegetativo emergente (VE); estádio cotiledonar (VC); o primeiro par de folhas unifoliadas é chamado V1; o estádio V2 é caracterizado pela presença da primeira folha trifoliada, todavia, a segunda folha trifoliada já tem que estar aberta, ou seja, suas bordas já não mais se encostam; o estádio V3 é caracteriazado pela presença da segunda folha trifoliada, todavia, a terceira folha trifoliada já tem que estar aberta, ou seja, suas bordas já não mais se encostam; V4, V5... e Vn possuem as mesmas características. Já o estádio reprodutivo tem seu inicío com o aparecimento da primeira flor aberta em qualquer lugar do caule, indicando R1. Rn será marcado pelo surgimento de mais flores pelo caule, e posteriormente o aparecimento das vagens, e o último estádio reprodutivo será o R8, onde pelo menos, 95\% das vagens estão maduras e prontas para serem coletadas (Figura 7) (FERH \& CAVINES, 1977; EMBRAPA; 2013).

O experimento consistiu de 3 exposições que duraram de Setembro de 2016 a Abril de 2017. Cada repetição teve a duração de 4 meses, no período da primavera/verão, no qual o crescimento da soja é intensificado. A primeira exposição foi iniciada em Setembro de 2016 e findou em Dezembro de 2016; a segunda foi iniciada em Novembro de 2016 e findou em Janeiro de 2017; e a última exposição foi iniciada em Janeiro de 2017 e findou em Abril de 2017. Em cada exposição foram coletadas as folhas em V3, V4 e V5 em cerca de 5 indivíduos em cada exposição. Todo material coletado foi pesado, armazenado em freezer $-80^{\circ} \mathrm{C}$ e posteriormente liofilizado. 


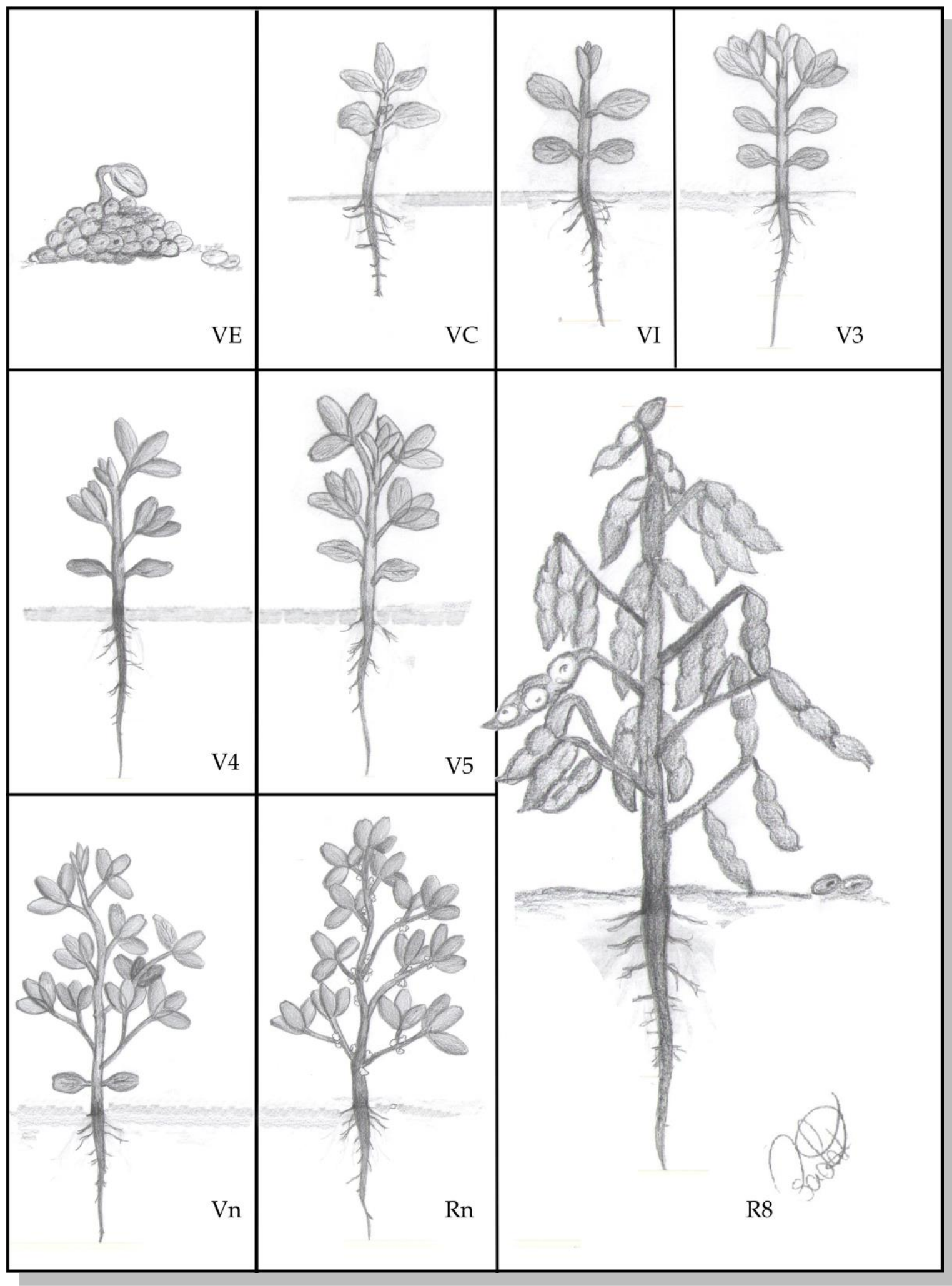

Figura 7: Estádios fenólicos da soja segundo FEHR \& CAVINESS (1977) e EMBRAPA (2013). VE: estádio emergente; VC: estádio cotiledonar; V1: Folha unifoliada aberta; V3: Segunda folha trifólia aberta; V4: Terceiro folha unifoliada aberta; V5: Quarto folha unifoliada aberta; Vn: número de folhas trifoliadas acompanha o cresciento vegetativo; Rn: número de flores indeterminado; R8: vagens maduras. Ilustração: Paola Tavares da Silva. 


\subsection{Preparo dos extratos}

Cerca de $20 \mathrm{mg}$ do material liofilizado e moído, foram extraídos em 1,4 mL de acetona 80\%. A maceração foi feita sob agitação constante por 3 horas. O sobrenadante foi retirado, armazenado em novo tubo e seu volume foi reduzido em concentrador do tipo SpeedVac. Após a segunda extração completa, o sobrenadante foi reunido ao da primeira extração e novamente reduzido em SpeedVac. Após a completa remoção da acetona, o extrato foi congelado e liofilizado.

\subsection{Composição química}

Para a análise do perfil e quantificação das substâncias fenólicas, o extrato liofilizado foi retomado em $1 \mathrm{~mL}$ de água ultra pura, onde parte foi analisada por cromatografia líquida de alta eficiência acoplada a detector de arranjo e diodos (CLAE-DAD) utilizando método modificado de (SANTOS et al., 2016). Os extratos foram filtrados em unidade filtrante (membrana durapore 0,45U - Milex) e analisados utilizando-se coluna Zorbax Eclipse Plus - C18 (150 X 4,6 mm, 3,5 $\mu \mathrm{m}$ - Agilent) segundo o gradiente de solventes: $90 \%$ de A e 10\% de B (0-6 minutos); 85\% de A e $15 \%$ de B (7- 32 minutos), $50 \%$ de A e $50 \%$ de B (32-42 minutos); $0 \%$ de A e $100 \%$ de B (4250 minutos); sendo A: ácido acético HPLC 0,1\% e B: acetonitrila. Variação do fluxo: $1 \mathrm{~mL} / \mathrm{min}$ e injeção de $3 \mu \mathrm{L}$ com uso de célula de fluxo de caminho óptico de $60 \mathrm{~mm}$. A detecção foi monitorada nos comprimentos $260 \mathrm{~nm}$ (isoflavonas), $280 \mathrm{~nm}$ (substâncias fenólicas em geral) e $352 \mathrm{~nm}$ (flavonas/flavonóis). Os resultados foram quantificados utilizando-se curvas de calibração de ácido p-cumárico (1,5 a $120 \mu \mathrm{g} / \mathrm{mL} ; \mathrm{y}=29272 \mathrm{x}-70,463$ e $\left.\mathrm{R}^{2}=0,9904\right)$, de quercetina $\left(1,5\right.$ a $150 \mu \mathrm{g} / \mathrm{mL} ; \mathrm{y}=17023 \mathrm{x}$ - 4,5312 e $\left.\mathrm{R}^{2}=0,9998\right)$ e genesteína $(0,3$ a $120 \mu \mathrm{g} / \mathrm{mL}$; $\mathrm{y}=40685 \mathrm{x}+59,54$ e $\left.\mathrm{R}^{2}=0,9999\right)$.

Para a identificação, as amostras foram submetidas à cromatografia líquida de alta eficiênicia acoplada à espectrometria de massas (CLAE-EM) na Central Analítica do Instituto de Química da USP em equipamento CLAE-30AD Shimadzu acoplado aos detectores SPD-20 ${ }^{a}$ Shimadzu e MAXI 3G Bruker Daltonics, utilizando coluna Zorbax Eclipse Plus - C18 (150 X 4,6 mm, 3,5 $\mu \mathrm{m}$ - Agilent) segundo o mesmo gradiente de solventes e condições de análise citados acima. Para a espectrometria de massas as condições foram: fonte ESI+ 500V, voltagem capilar $4500 \mathrm{~V}$, nebulizador a 2 bar, gás secante a $200^{\circ} \mathrm{C}$ e fluxo de $8 \mathrm{~L} \mathrm{~min}^{-1}$. Aquisição realizada em módulo negativo.

A seguir encontra-se um esquema simplificado da metodologia de trabalho (Figura 8). 


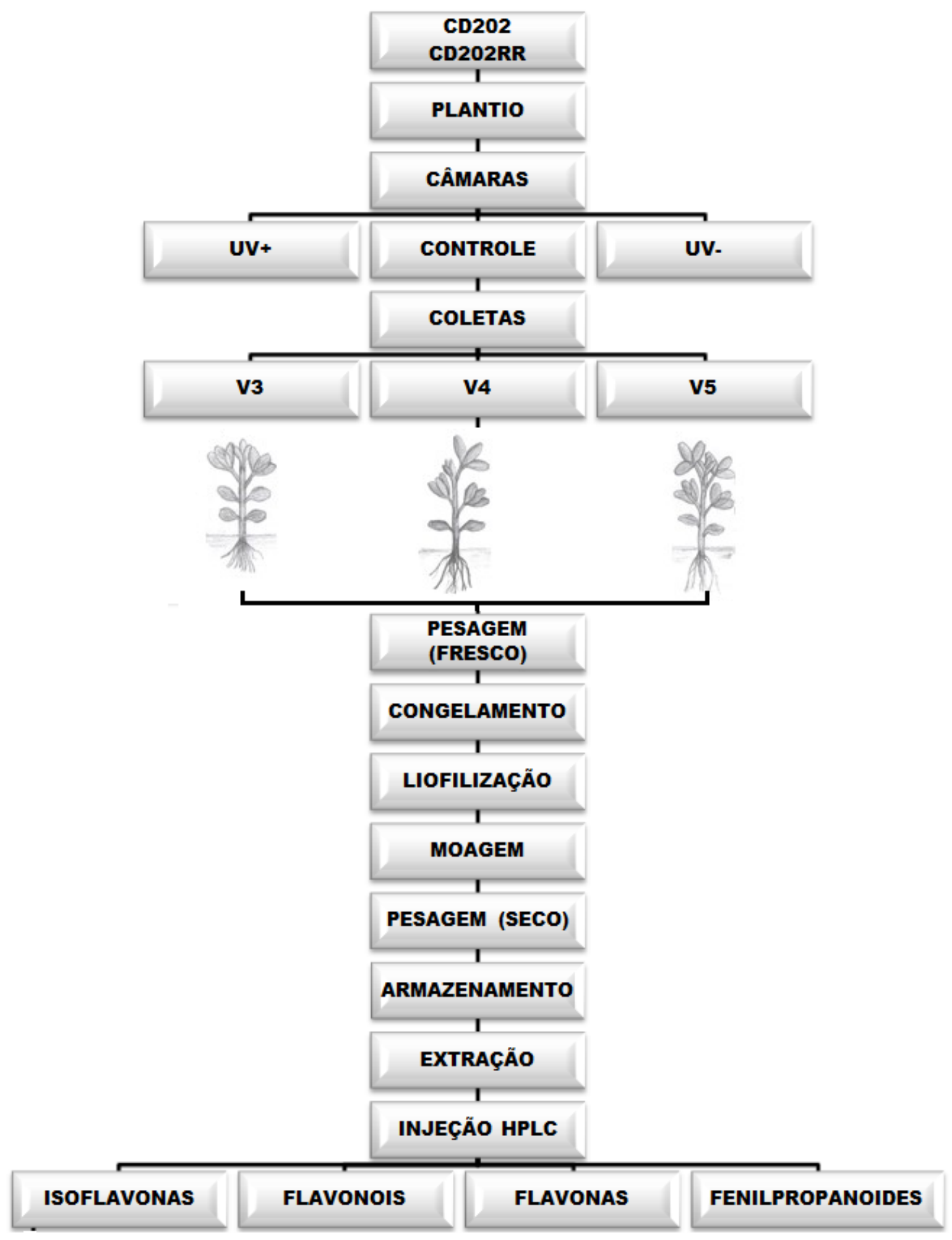

Figura 8. Esquema simplificado da metodologia de trabalho. 


\subsection{Análise de dados}

A princípio se avaliou se os três experimentos apresentavam diferenças significativas entre si. Uma vez detectado que não eram diferentes, os resultados das repetições foram unidos $(n=15)$ e a análise estatística levou em conta a comparação: 1. efeito do desenvolvimento para cada câmara, comparação dos estádios dois a dois; 2. efeito da exposição - para cada estádio, comparação das câmaras duas a duas. A análise de variância (Two Way Anova) foi realizada no programa Origin® versão 9.5 (2018), com teste post-hoc de Bonferroni. O nível de significância adotado foi $\mathrm{P}<0,05$. Todas as variáveis foram testadas com relação a normalidade e homocedasticidade.

Análise multivariada foi realizada utilizando-se a análise de componente principal (PCA) pelo programa Fitopac versão 2.1 (SHEPHERD, 2010). Heat-maps foram feitos utilizando a plataforma Morpheus (https://software.broadinstitute.org/morpheus).

Todos os resultados estão expressos em média \pm desvio padrão $(\mathrm{n}=15)$. 


\section{Resultados e Discussão}

Foram semeados cerca de 100 vasos por experimento, com aproximadamente $95 \%$ das sementes germinadas e chegando a fase de coleta. Foram feitas coletas de três estádios vegetativos, sendo eles V3, V4 e V5.

Analisando o tempo em dias para atingir os diferentes estádios de desenvolvimento podemos observar que tanto para germinação quanto para o florescimento, os cultivares estudados neste trabalho se desenvolveram de maneira similar à descrita para o clima de São Paulo, quando comparado ao seu local de distribuição que é o Estado do Rio Grande do Sul (Tabela 1).

VERNETTI JUNIOR e AGUILA (2012) em seu trabalho avaliaram cultivares que são registrados na Rede de Soja Sul de Pesquisa, estes usados para o cultivo nos Estados do Sul do Brasil. Como resultados obtiveram a maturação de sementes precoces e tardias. Os cultivares usados neste trabalho, CD202 e CD202RR foram considerados de ciclo precoce, com tempo de germinação a floração de 66 dias, similar ao observado no presente estudo. Entretanto, quanto maior a temperatura durante a exposição, mais rápida foi a germinação e menor o tempo para se atingir a floração. Na tabela 1, podemos observar para as duas últimas exposições (E2 e E3) menores períodos entre a germinação e a floração quando comparados aos resultados de VERNETTI JUNIOR e AGUILA (2012), 66 dias. Provavelmente, as maiores temperaturas e umidade que a estação do verão, na cidade de São Paulo, apresentou durante as exposições E2 e E3, podem explicar o desenvolvimento mais rápido de ambos os cultivares quando comparado ao que ocorreu no Sul do Brasil.

Tabela 1. Número de dias entre a germinação e o florescimento de soja das variedades CD202 e CD202RR mantidas nas diferentes exposições.

\begin{tabular}{lccc}
\hline \multicolumn{3}{l}{ Germinação/ Emergência } & primeira flor por Exposição (E) \\
\hline Variedade & $\mathrm{N}^{\circ}$ dias E1 & $\mathrm{N}^{\mathrm{o}}$ dias E2 & $\mathrm{N}^{\mathrm{o}}$ dias E3 \\
CD202 & 65 & 60 & 50 \\
CD202RR & 65 & 60 & 55 \\
\hline
\end{tabular}

Ainda observando o desenvolvimento das plântulas, observamos que as plantas expostas ao tratamento $\mathrm{UV}+$ apresentam um menor rendimento em massa de suas folhas do que as plântulas cultivadas nos outros dois tratamentos. As folhas das plântulas no tratamento UV+ desenvolveram menores tamanhos e apresentaram danos visíveis do tipo cloroses, não observadas no controle e tratamento UV- (Figura 9A e 9B). 


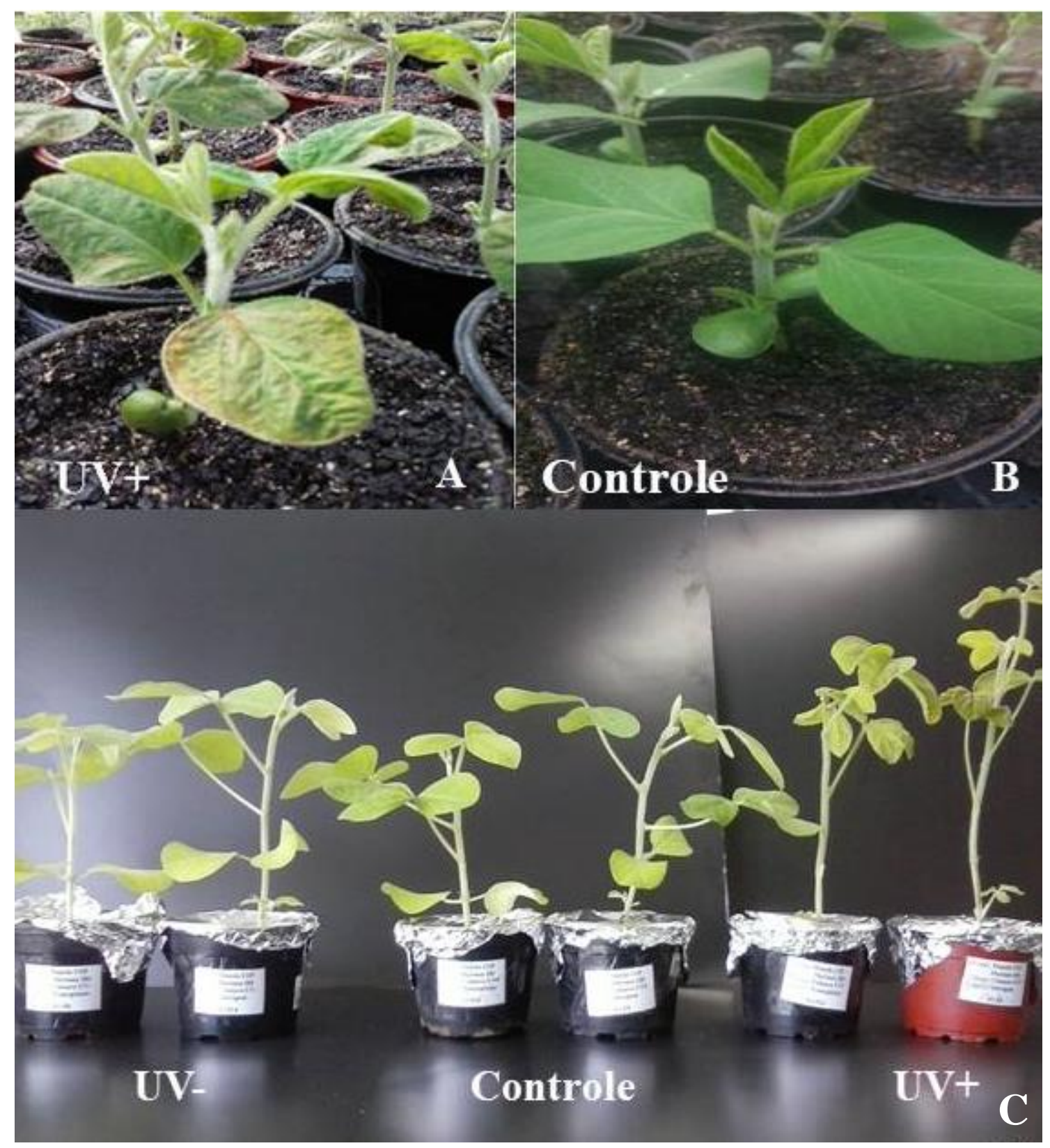

Figura 9. A e B: Sojas em estádio V1. A: Tratamento UV+, folhas já apresentam dano devido a radiação UV; B: Tratamento Controle sem danos visíveis. C: Sojas em estádio V4. Exposição $\mathrm{UV}+$ leva ao estiolamento das plantas, enquanto que os tratamentos Controle e UV- possuem alturas similares. Fotos: Pâmela Tavares da Silva. 
Esse dano é corroborado por trabalhos como os de MARKHAM et al., (1998); KOVACS \& KERESZTES (2002); PAUL (2000); TOPCU et al., (2015); ZAVALA et al., (2015), que demonstram que danos no crescimento foliar são costumeiros quando há exposição a um excesso de radiação UV, e não apenas isso, danos ao DNA e produção de espécies reativas de oxigênio são esperados, uma vez que são produtos do extresse oxidativo sofrido pela planta. Por se tratar de uma espécie importante na alimentação e produção de biocombustível, entre outras utilizações, a realocação de recursos para a produção de substâncias de defesa pode refletir em modificações morfológicas, redução de biomassa e alterações na síntese de metabólitos primários como açúcares solúveis e lipídeos, influenciando a produtividade final. A tabela 2 apresenta os rendimentos em massa foliar fresca e seca, respectivamente, obtidas nas exposições para o cultivar CD202 e CD202RR.

Podemos observar na tabela 2, que o tratamento UV+, para ambos cultivares, apresenta, em média, menores massas foliares do que as apresentadas pelos tratamentos Controle e UV-, evidenciada pela diferença significativa encontrada para a maioria das exposições. Aparentemente, não há um efeito do desenvolvimento na massa foliar, uma vez que não foram verificadas diferenças significantes entre os estágios quando comparados entre si para cada câmara.

Na figura 9C, podemos notar que houve uma diferença na altura entre plantas que se desenvolveram nas diferentes câmaras. Esse resultado corrobora aos encontrados na literatura (TERAMURA \& MURALI, 1986; FINCKH et al., 1995; BARNES et al., 1996; KOTI et al., 2007; KATARIA \& GURUPRASAD, 2012a; KATARIA et al., 2014b), os quais verificaram que exposição prolongada e alta radiação UV, em cultivares de soja ou em outras espécies vegetais, como Arabidopsis thaliana e Oryza sativa L. pode gerar danos morfológicos, fisiológicos ou no incremento de biomassa. TERMURA e MURALI (1986) fizeram um trabalho com 23 cultivares de soja expostos durante três horas diárias à radiação UV entre 110-120 dias (foram feitas coletas nos estádios reprodutivos R6 e R8). Os autores verificaram que em grande parte dos cultivares ouve uma diminuição do tamanho, da área foliar e da produção de sementes, com diferença significativa de $\mathrm{p}<0,05$. 
Tabela 2. Médias ( \pm desvio padrão) das massas foliares frescas e secas (g) de Glicyne max para as câmaras Controle, UV- (ausência parcial de luz UV) e UV+ (acréscimo de luz UV) para cada estádio de desenvolvimento vegetativo analisado (V3, V4 e V5).

\begin{tabular}{|c|c|c|c|c|c|c|c|c|c|}
\hline \multicolumn{10}{|c|}{ Cultivar CD202 } \\
\hline \multicolumn{10}{|c|}{ Massa fresca $(\mathrm{g})$} \\
\hline & \multicolumn{3}{|c|}{ Controle } & \multicolumn{3}{|c|}{ UV- } & \multicolumn{3}{|c|}{$\mathrm{UV+}$} \\
\hline Exp & $\mathrm{V} 3$ & $\mathrm{~V} 4$ & $\mathrm{~V} 5$ & $\mathrm{~V} 3$ & $\mathrm{~V} 4$ & V5 & $\mathrm{V} 3$ & $\mathrm{~V} 4$ & V5 \\
\hline 1 & $0,74 \pm 0,02 \mathrm{aA}$ & $0,63 \pm 0,07 \mathrm{aA}$ & $0,63 \pm 0,06 \mathrm{aA}$ & $0,56 \pm 0,07 \mathrm{aA}^{*}$ & $0,66 \pm 0,10 \mathrm{aA}$ & $0,65 \pm 0,10 \mathrm{aA}$ & $0,28 \pm 0,07 \mathrm{aA}^{*}$ & $0,45 \pm 0,04 \mathrm{bA}^{*}$ & $0,33 \pm 0,07 \mathrm{abA}^{* \#}$ \\
\hline 2 & $0,36 \pm 0,08 \mathrm{aB}$ & $0,47 \pm 0,10 \mathrm{aA}$ & $0,43 \pm 0,12 \mathrm{aA}$ & $0,47 \pm 0,03 \mathrm{aA}^{*}$ & $0,29 \pm 0,07 \mathrm{bB} *$ & $0,37 \pm 0,07 \mathrm{abB}$ & $0,38 \pm 0,06 \mathrm{aA}$ & $0,35 \pm 0,06 \mathrm{aA}$ & $0,25 \pm 0,07 \mathrm{abA}^{*}$ \\
\hline 3 & $0,37 \pm 0,03 \mathrm{aB}$ & $0,51 \pm 0,06 \mathrm{aA}$ & $0,50 \pm 0,22 \mathrm{aA}$ & $0,35 \pm 0,05 \mathrm{aAB}$ & $0,50 \pm 0,09 \mathrm{aA}$ & $0,54 \pm 0,12 \mathrm{abAB}$ & $0,2 \pm 0,04 \mathrm{aAB}$ & $0,17 \pm 0,03 \mathrm{aB}^{* \#}$ & $0,10 \pm 0,05 \mathrm{aB}^{* \#}$ \\
\hline \multicolumn{10}{|c|}{ Massa seca $(\mathrm{g})$} \\
\hline & \multicolumn{3}{|c|}{ Controle } & \multicolumn{3}{|c|}{$\mathrm{UV}-$} & \multicolumn{3}{|c|}{$\mathrm{UV}+$} \\
\hline Exp & $\mathrm{V} 3$ & $\mathrm{~V} 4$ & $\mathrm{~V} 5$ & $\mathrm{~V} 3$ & $\mathrm{~V} 4$ & $\mathrm{~V} 5$ & $\mathrm{~V} 3$ & $\mathrm{~V} 4$ & $\mathrm{~V} 5$ \\
\hline 1 & $0,17 \pm 0,01 \mathrm{aA}$ & $0,13 \pm 0,02 \mathrm{aA}$ & $0,14 \pm 0,02 \mathrm{aA}$ & $0,12 \pm 0,02 \mathrm{aA}^{*}$ & $0,14 \pm 0,02 \mathrm{aA}$ & $0,15 \pm 0,02 \mathrm{aA}$ & $0,05 \pm 0,01 \mathrm{aA} *$ & $0,09 \pm 0,01 \mathrm{bA}^{* \#}$ & $0,07 \pm 0,01 \mathrm{abA}{ }^{* \#}$ \\
\hline 2 & $0,07 \pm 0,02 \mathrm{aB}$ & $0,09 \pm 0,02 \mathrm{aA}$ & $0,09 \pm 0,03 \mathrm{aA}$ & $0,11 \pm 0,01 \mathrm{aA} *$ & $0,06 \pm 0,02 \mathrm{bB}$ & $0,08 \pm 0,02 \mathrm{abB}$ & $0,07 \pm 0,01 \mathrm{aA}^{\#}$ & $0,07 \pm 0,01 \mathrm{aA}$ & $0,05 \pm 0,01 \mathrm{aA} *$ \\
\hline 3 & $0,09 \pm 0,01 \mathrm{aB}$ & $0,12 \pm 0,02 \mathrm{aA}$ & $0,11 \pm 0,05 \mathrm{aA}$ & $0,08 \pm 0,01 \mathrm{aAB}$ & $0,14 \pm 0,02 \mathrm{bA}$ & $0,11 \pm 0,03 \mathrm{abB}$ & $0,04 \pm 0,01 \mathrm{aAB} *$ & $0,03 \pm 0,01 \mathrm{aB}^{* \#}$ & $0,02 \pm 0,01 \mathrm{aB}^{* \#}$ \\
\hline \multicolumn{10}{|c|}{ Cultivar CD202RR } \\
\hline \multicolumn{10}{|c|}{ Massa Fresca (g) } \\
\hline & \multicolumn{3}{|c|}{ Controle } & \multicolumn{3}{|c|}{$\mathrm{UV}-$} & \multicolumn{3}{|c|}{$\mathrm{UV+}$} \\
\hline Exp & $\mathrm{V} 3$ & $\mathrm{~V} 4$ & V5 & $\mathrm{V} 3$ & $\mathrm{~V} 4$ & $\mathrm{~V} 5$ & $\mathrm{~V} 3$ & $\mathrm{~V} 4$ & $\mathrm{~V} 5$ \\
\hline 1 & $0,09 \pm 0,03 \mathrm{aA}$ & $0,13 \pm 0,02 \mathrm{aA}$ & $0,11 \pm 0,01 \mathrm{aA}$ & $0,10 \pm 0,05 \mathrm{aA}$ & $0,13 \pm 0,03 \mathrm{aA}$ & $0,09 \pm 0,04 \mathrm{aA}$ & $0,05 \pm 0,01 \mathrm{aA}$ & $0,08 \pm 0,01 \mathrm{aA}$ & $0,06 \pm 0,00 \mathrm{abA}$ \\
\hline 2 & $0,08 \pm 0,03 \mathrm{aA}$ & $0,08 \pm 0,02 \mathrm{aA}$ & $0,07 \pm 0,02 \mathrm{aA}$ & $0,06 \pm 0,01 \mathrm{aA}$ & $0,08 \pm 0,01 \mathrm{aA}$ & $0,08 \pm 0,01 \mathrm{aA}$ & $0,06 \pm 0,01 \mathrm{aA}$ & $0,07 \pm 0,01 \mathrm{bA}$ & $0,04 \pm 0,01 \mathrm{aA}$ \\
\hline 3 & $0,08 \pm 0,01 \mathrm{aA}$ & $0,10 \pm 0,02 \mathrm{aA}$ & $0,08 \pm 0,04 \mathrm{aA}$ & $0,08 \pm 0,01 \mathrm{aA}$ & $0,08 \pm 0,02 \mathrm{aA} \quad 0$ & $, 10 \pm 0,02 \mathrm{aA}$ & $0,04 \pm 0,01 \mathrm{aAB}^{* \#}$ & $0,03 \pm 0,01 b^{* \#}$ & $0,03 \pm 0,01 \mathrm{aAB}^{* \#}$ \\
\hline \multicolumn{10}{|c|}{ Massa Seca $(\mathrm{g})$} \\
\hline & \multicolumn{3}{|c|}{ Controle } & \multicolumn{3}{|c|}{$\mathrm{UV}-$} & \multicolumn{3}{|c|}{$\mathrm{UV+}$} \\
\hline Exp & $\mathrm{V} 3$ & $\mathrm{~V} 4$ & $\mathrm{~V} 5$ & $\mathrm{~V} 3$ & $\mathrm{~V} 4$ & $\mathrm{~V} 5$ & $\mathrm{~V} 3$ & $\mathrm{~V} 4$ & $\mathrm{~V} 5$ \\
\hline 1 & $0,41 \pm 0,17 \mathrm{bA}$ & $0,64 \pm 0,09 \mathrm{aA}$ & $0,47 \pm 0,04 \mathrm{abA}$ & $0,50 \pm 0,24 \mathrm{aA}$ & $0,62 \pm 0,12 \mathrm{aA}$ & $0,47 \pm 0,04 \mathrm{aA}$ & $0,28 \pm 0,08 \mathrm{bA}$ & $0,42 \pm 0,05 \mathrm{aA}$ & $0,30 \pm 0,02 \mathrm{abA}$ \\
\hline 2 & $0,38 \pm 0,10 \mathrm{aA}$ & $0,36 \pm 0,06 \mathrm{aB}$ & $0,32 \pm 0,07 \mathrm{aA}$ & $0,24 \pm 0,04 \mathrm{aA}$ & $0,32 \pm 0,04 \mathrm{aB}$ & $0,33 \pm 0,06 \mathrm{aA}$ & $0,32 \pm 0,06 \mathrm{aA}$ & $0,34 \pm 0,06 \mathrm{aA}$ & $0,20 \pm 0,06 \mathrm{abAB}$ \\
\hline 3 & $0,35 \pm 0,04 \mathrm{aA}$ & $0,46 \pm 0,10 \mathrm{aAB}$ & $0,37 \pm 0,16 \mathrm{aA}$ & $0,36 \pm 0,04 \mathrm{aA}$ & $0,37 \pm 0,06 \mathrm{aB}$ & $0,43 \pm 0,05 \mathrm{aA}$ & $0,21 \pm 0,06 \mathrm{aA}$ & $0,15 \pm 0,04 \mathrm{aB}^{* \#}$ & $0,11 \pm 0,02 \mathrm{aB}^{* \#}$ \\
\hline
\end{tabular}

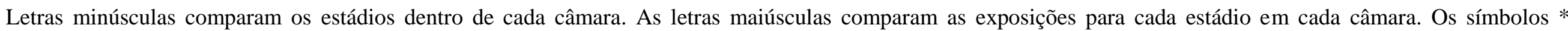

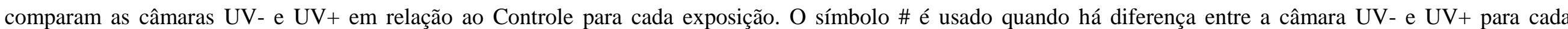
exposição. Exp: Exposições. 
KOTI e colaboradores (2007) trabalharam com diferentes cultivares de soja encontradas na China, combinando incremento de temperatura, $\mathrm{CO}_{2}$ e radiação UV-B. O tratamento com a radiação UV-B foi desenvolvido desde o plantio das sojas. Para os resultados obtidos para o tratamento com UV-B foi verificado uma diferença significativa para todos os parâmetros analisados, sendo eles altura da planta, área foliar, biomassa, fotossíntese, conteúdo fenólico, conteúdo de clorofila, conteúdo de ceras e injúrias foliares. A estatística foi baseada em três níveis de significância, sendo $\mathrm{p}<0,001 ; \mathrm{p}<0,01$ e $\mathrm{p}<0,05$; e para as variáveis descritas acima, a diferença ficou em $\mathrm{p}<0,001$, mostrando que o tratamento influenciou fortemente $o$ desenvolvimento dos cultivares quando comparado ao do grupo Controle.

Trabalhos desenvolvidos na Austrália (ROBINSON et al., 2005; WILLIAMSON et al., 2014; BORNMAN et al., 2015; ROBINSON \& ERICKSON, 2015) focaram nas mudanças ambientais e como estas impactam os ecossistemas marinho e terrestre, uma vez que as localidades estudadas ficam sob uma zona de depleção da camada de ôzonio, logo, se consegue prever, por modelagem, os impactos gerados no clima do Hemisfério Sul.

ROBINSON \& ERICKSON (2015) em seu trabalho mostram que as mudanças ambientais vão muito além do aumento da radiação UV, são mais expressivas tanto no ambiente terrestre quanto marinho, no nível de alterações fisicas dos ambientes, no crescimento das árvores do Hemisfério Sul e na alteração da biodiversidade nos lagos e dos mugos da Antártida. As mudanças climáticas (precipitação e temperatura) do Hemisfério Sul foram mais significativas para os ecossistemas naturais e produção de alimentos do que o aumento da radiação UV. A taxa de crescimento de Ceratodon purpureus (uma espécie de musgo), diminuiu três vezes em dois locais nas Ilhas Windmill, no leste da Antártida, desde à década de 1980, onde se observou também uma dimuição da disponibilidade de água próxima aos musgos e uma mudança na velocidade do vento durante o verão.

O Acordo de Paris, assinado em dezembro de 2015, tem como objetivo manter aumentos na temperatura média global abaixo de $2^{\circ} \mathrm{C}$ e buscar esforços para limitar o aumento da temperatura a $1,5^{\circ} \mathrm{C}$ acima dos níveis pré-industriais (ROGELJ et al., 2016). Este objetivo é importante para evitar maiores danos à vegetação, à produção agrícola e ao desenvolvimento econômico. A atividade humana é a principal causa do aquecimento global devido ao aumento das concentrações de gases de efeito estufa (IPCC, 2014). As atividades humanas ao longo do último século culminaram em temperaturas mais altas na atmosfera e nos oceanos, neve e gelo diminuídos, elevação do nível do mar, aumento da radiação UV-B e mudança climática no Hemisfério Sul, como resultado da destruição da camada de ozônio (ROBINSON \& 
ERICKSON, 2015). Essa mudança climática afeta diretamente os ecossistemas naturais e em manejo e os organismos vivos que os habitam (PECL et al., 2017). Essa combinação de diferentes estressores ambientais pode atuar sinergicamente, tornando-se prejudicial à sobrevivência das plantas (SAVVIDES et al., 2016). Estresses abióticos como aumento da radiação UV, seca, inundação, frio extremo e calor, salinidade, poluição do ar e da água têm um impacto significativo no crescimento das plantas em todo o mundo.

Segundo KUTCHAN (2001), os metabólitos especiais representam uma interface química entre as plantas e o ambiente ao seu redor e, por isso, sua síntese é frequentemente afetada por condições ambientais como altitude, disponibilidade de água e macro e micronutrientes no solo, temperatura e $\mathrm{pH}$ do solo, entre outros. Apesar da reconhecida influência dos fatores ambientais no desenvolvimento das plantas, mas existem poucos estudos mostrando as relações e adaptações fisiológicas das plantas ao meio ambiente.

Na tabela 3 podemos verificar a composição fenólica dos cultivares CD202 e CD202RR utilizando-se CLAE-MS. Foram detectadas 28 substâncias sendo 13 derivados do ácido cinâmico, 9 flavonoides e 6 isoflavonoides. Para os derivados do ácido cinâmico, temos 5, 6 e 7 sugeridos como siringina, um possível isômero e siringina monohidratado, respectivamente; 9 e 10 sendo isômeros de ácido cafeoilquínico e $\mathbf{1 1}$ e $\mathbf{1 2}$ sendo isômeros de ácido feruloilquínico. Entre os flavonoides, o flavonol campferol é o principal esqueleto aglicônico encontrado, aparecendo nas forma de triglicosideo (substâncias 14, 15, 17 e 18) e diglicosideo (substâncias 16, 20 e 22), os outros dois constituintes 23 e 25 são derivados de apigenina (uam flavona). Entre os 6 isoflavonoides foi possível identificar as substâncias 19, 24 e 27 como derivados acilados de genisteína: acetil-genistina, malonil-genistina e genisteína malonil-glicosídeo. O constituinte 21 foi sugerido como sendo um derivado acilado de daidzeína, acetil-daidzina. O constituinte 26 foi sugerido como um derivado de genisteína; e o constituinte 28 é uma isoflavona, mas não foi possível sua identificação. Na figura 10 podemos observar os cromatogramas obtidos para o cultivar cultivar CD202 (10 ) e CD202RR (10B). Na figura 11 podemos observar os espectros de absorção UV-Vis de cada constituinte detectado. 


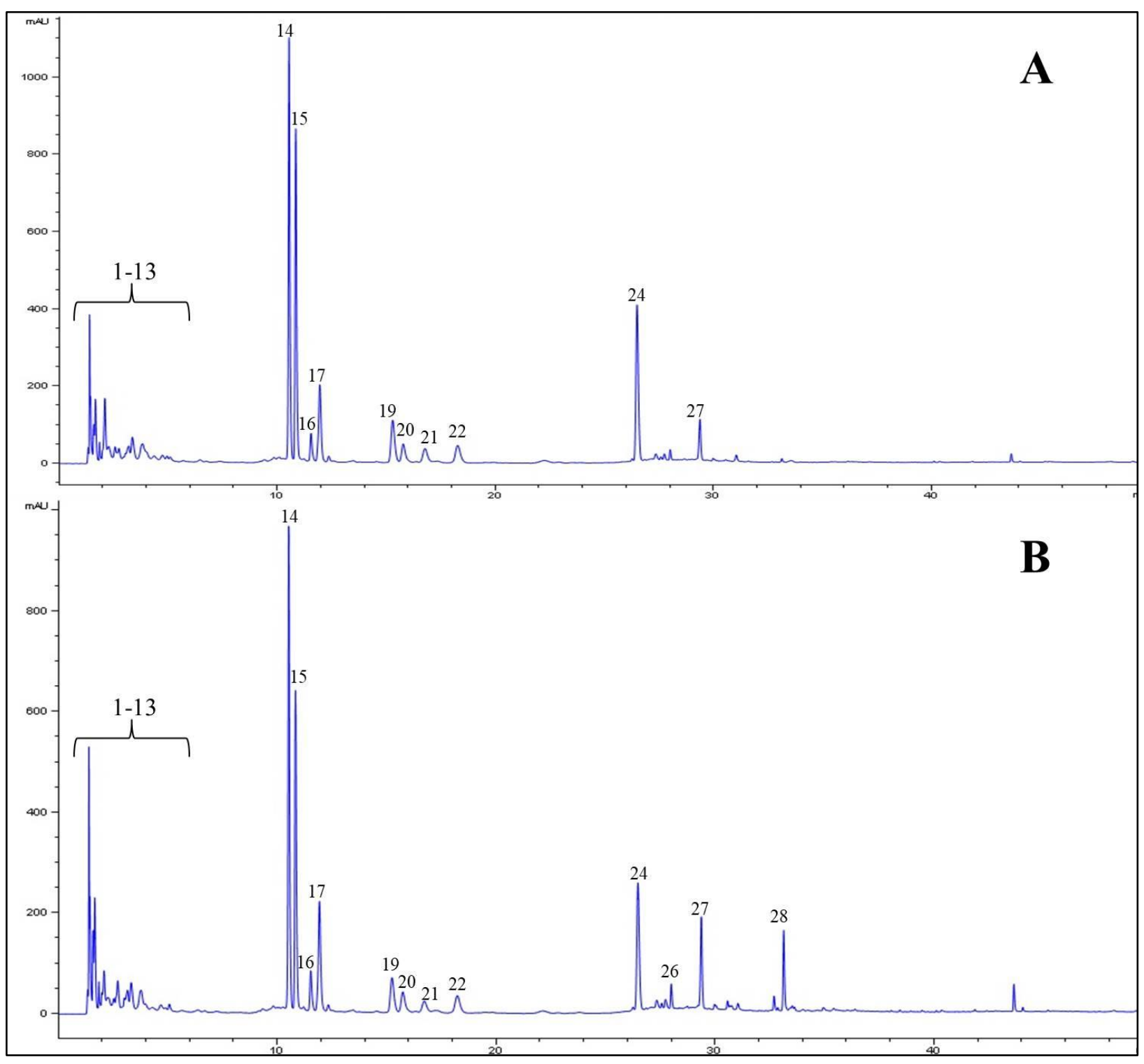

Figura 10: Cromatogramas no comprimento de onde $260 \mathrm{~nm}$, mostrando alguns dos contituintes marjoritários da soja. A: cultivar CD202 e B: cultivar CD202RR.

HO et al. (2002) encontraram em folhas de soja 6 flavonóis derivados de campferol e uma flavona não identificada: campferol-3-O-ramnosil-glucosil-galactosídeo $\left([\mathrm{M}+\mathrm{H}]^{+} \mathrm{m} / \mathrm{z}, 757\right)$; campferol-3-O-diramnosil-glucosídeo $\quad\left([\mathrm{M}+\mathrm{H}]^{+} \quad \mathrm{m} / z \quad 741\right) ; \quad$ campferol-3-O-digalactosideo $\left([\mathrm{M}+\mathrm{H}]^{+} m / z\right.$ 611); campferol-3-O-diglucosideo $\left([\mathrm{M}+\mathrm{H}]^{+} \mathrm{m} / z\right.$ 611); campferol-3-O-ramnosilgalactosideo $\left([\mathrm{M}+\mathrm{H}]^{+} \mathrm{m} / z\right.$ 595); e campferol-3-O-rutinosideo $\left([\mathrm{M}+\mathrm{H}]^{+} \mathrm{m} / z\right.$ 595), composição muito similar a encontrada no presente estudo. No presente estudo, os cultivares estudados apresentaram 7 derivados de campferol, um a mais que o descrito por Ho et al. (2002), e dois derivados de apigenina (flavona) não identificados com relação as suas substituições.

Da mesma forma, os mesmos autores descreveram as isoflavonas genistina e malonilgenistina como constituintes de folhas de sojas. No presente estudo, não detectamos genistina 
nos cultivares analisados, mas sim seus derivados acilados acetil- e malonil-genistina $(\mathbf{1 9}, \mathbf{2 7})$. Dois constituintes isômeros $\left([\mathrm{M}-\mathrm{H}]^{-} \mathrm{m} / \mathrm{z}\right.$ 517) foram detectados, podendo corresponder à malonil-genistina (24 e 27) já descrita para a soja por Ho et al. (2002). Além disso, também detectamos o constituinte acetil-daidzina, além de um derivado de genisteína e uma isoflavona não identificada (Tabela3).

Com relação ao efeito dos tratamentos na composição fenólica da soja, as tabelas 4 e 5 apresentam os constituintes majoritários detectados por CLAE/DAD, para os cultivares CD202 e CD202RR, respectivamente. Comparando-se a composição de fenólicos entre os cultivares, pode-se verificar a grande semelhança entre eles, tanto na composição quanto nas quantidades apresentadas de cada constituinte.

Os compostos marjoritários foram os flavonóis seguidos pelos derivados do ácido cinâmico, ambos conhecidos pela sua capacidade antioxidante e por atuarem na defesa frente a estresses bióticos e abióticos, como a radiação UV, herbivoria, entre outros (VIDOVIĆ et al., 2015; ZAVALA et al., 2015). Entre os flavonoides, as isoflavonas, classe característica na família e para a espécie estudada, também foram detectadas neste estudo. Isoflavonas também são conhecidas por sua atividade antioxidante, apresentando aumento em seus conteúdos quando a planta está sob estresse oxidativo (YUK et al., 2011a, 2016b; ZAVALA et al., 2015).

Para melhor visualizar o efeito dos tratamentos, nossa primeira abordagem foi agrupar os constituintes detectados em três classes de substâncias fenólicas: flavonoides, isoflavonoides e derivados do ácido cinâmico. Para essa análise a estatística mostrou que as exposições não diferiram significativamente entre si e, portanto, nosso $n$ amostral foi o total de 15 plantas utilizadas ao longo dos três períodos de exposição. Uma vez que analisamos três estádios consecutivos, nossos resultados foram avaliados sob dois aspectos: 1. para cada câmara foram comparados os estádios entre si e, neste caso, os resultados apontam mudanças na composição fenólica ao longo do desenvolvimento da planta (Figura 12); 2. para cada estádio comparamos os valores entre as câmaras e, neste caso, os resultados mostram o efeito do tratamento (Controle, UV+ e UV-) (Figura 13). Em ambas as figuras, o cultivar CD202 é representado pelas letras A, B e C; já o cultivar CD202RR é representado pelas letras D, E e F. 
Tabela 3: Composição fenólica observada utilizando-se CLAE-DAD e CLAE-EM para os cultivares CD202 e CD202RR.

\begin{tabular}{|c|c|c|c|c|c|}
\hline & $\operatorname{Tr}(\min )$ & espectro absorção UV-Vis (nm) & {$[\mathrm{M}-\mathrm{H}]^{-}$} & Fragmentos $(\mathrm{m} / \mathrm{z})$ & Sugestão \\
\hline 1 & 1,39 & 266,216 & 195,0508 & 75,0085 & NI \\
\hline 2 & 1,43 & 302,262 & & & Derivado cinâmico \\
\hline 3 & 1,58 & 304,260 & 299,0983 & 149,0458 & Derivado cinâmico \\
\hline 4 & 2,08 & 326,300 (om), 248 & 371,0609 & 315,$0716 ; 164,0710$ & Derivado cinâmico \\
\hline 5 & 2,27 & 328,302 (om), 248 & 371,0616 & 315,$0716 ; 209,0801$ & Siringina \\
\hline 6 & 2,54 & 324, 296 (om), 242 & 371,0625 & 315,$0716 ; 209,0306$ & Siringina isômero \\
\hline 7 & 2,64 & 312,298 (om), 228 & 389,0721 & 371,$0617 ; 209,0301$ & Siringina monohidratado \\
\hline 8 & 2,72 & 312,298 (om), 226 & 371,0607 & 209,0297 & Derivado cinâmico \\
\hline 9 & 2,94 & 322,298 (om), 240 & 353,0668 & 191,0193 & Ácido cafeoilquínico \\
\hline 10 & 3,17 & 308,268 om), 220 & 353,0666 & 191,0195 & Ácido cafeoilquínico \\
\hline 11 & 3,34 & $326,298(\mathrm{om}), 240,218(\mathrm{om})$ & 385,0770 & 193,0499 & Ácido feruloilquínico \\
\hline 12 & 3,79 & $320,296(\mathrm{om}), 238$ & 385,0765 & 193,0508 & Ácido feruloilquínico \\
\hline 13 & 5,08 & 328,298 (om), 240 & 385,0770 & 191,0193 & Derivado cinâmico \\
\hline 14 & 10,53 & 350,294 (om), 266 & 755,2020 & 377,$0977 ; 575,1399 ; 284,0825$ & Campferol dihexosil-ramnosídeo \\
\hline 15 & 10,84 & 352,296 (om), 264 & 755,2028 & 377,$0979 ; 575,1386 ; 284,0322$ & Campferol dihexosil-ramnosídeo \\
\hline 16 & 11,54 & 358,264 & 609,1406 & 429,$0907 ; 284,0316$ & Campferol dihexosideo \\
\hline 17 & 11,94 & 358,264 (om), 224 & 739,2079 & 575,$1405 ; 284,0323$ & Campferol diramnosil-hexosídeo \\
\hline 18 & 12,34 & 350,294 (om), 264 & 739,2068 & 576,$1461 ; 284,0318$ & Campferol diramnosil-hexosídeo \\
\hline 19 & 15,28 & 302,260 & 491,1183 & 431,$0976 ; 269,0450$ & Acetil-genistina \\
\hline 20 & 15,76 & 350,292 (om), 264 & 593,1506 & 284,0317 & Campferol dihexosídeo \\
\hline 21 & 16,76 & 302,252 & 457,1125 & 253,0508 & Acetil-daidzina \\
\hline 22 & 18,26 & 348, 298 (om), 264 & 593,1500 & 285,0400 & Campferol hexosil-ramnosideo \\
\hline 23 & 22,15 & 334,268 & & & Derivado de Apigenina \\
\hline 24 & 26,48 & 302,260 & 517,0968 & 473,$10 ; 269,0453$ & Malonil-genistina \\
\hline 25 & 27,73 & 336,268 & & & Derivado de Apigenina \\
\hline 26 & 28,00 & 302,260 & 519,1493 & 505,$1337 ; 297,0770 ; 269,0446$ & Derivado de Genesteína \\
\hline 27 & 29,36 & 308,260 & 517,0960 & 473,$1066 ; 269,0448$ & Genisteína malonil-glicosideo \\
\hline 28 & 33,13 & 308,260 & 523,1626 & 417,$0915 ; 335,1702 ; 267,0651$ & Isoflavona \\
\hline
\end{tabular}



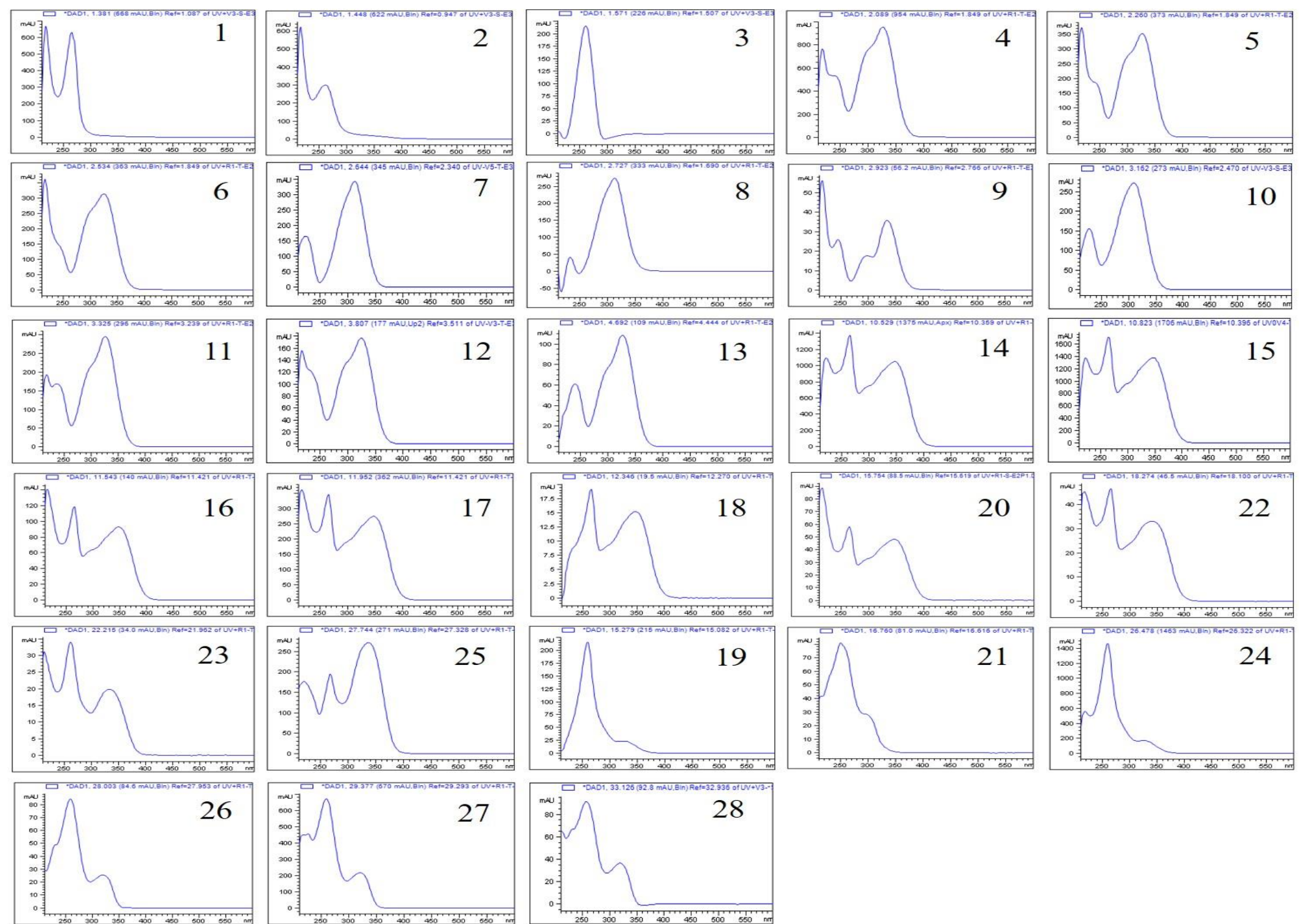

Figura 11: Espectros de absorção UV-Vis $(200-660 \mathrm{~nm})$ das substâncias encontradas para os cultivares CD202 e CD202RR. Os números correspondem a identificação encontrada na tabela 3. 
Tabela 4: Constituintes da variedade CD202, em mg/g, para as câmaras Controle, UV- (ausência parcial de luz UV) e UV+ (acréscimo de luz UV). Valores médios para cada constituinte em cada estádio. Letras minúsculas indicam se há diferença entre os estádios vegetativos. Letras maiúsculas indicam se há diferenças entre as câmaras.

\begin{tabular}{|c|c|c|c|c|c|c|c|c|c|c|}
\hline & \multirow{2}{*}{$\operatorname{Tr}(\min )$} & \multicolumn{3}{|c|}{ Controle } & \multicolumn{3}{|c|}{ UV- } & \multicolumn{3}{|c|}{$\mathrm{UV}+$} \\
\hline & & V3 & $\mathrm{V} 4$ & V5 & V3 & V4 & V5 & V3 & $\mathrm{V} 4$ & V5 \\
\hline 1 & 1,38 & & & & & & & $0,16 \pm 0,05^{\mathrm{aA}}$ & $0,19 \pm 0,05^{\mathrm{aA}}$ & $0,21 \pm 0,06^{\mathrm{aA}}$ \\
\hline 2 & 1,44 & & $0,14 \pm 0,00^{\mathrm{aA}}$ & $0,16 \pm 0,03^{\mathrm{aA}}$ & $0,15 \pm 0,05^{\mathrm{aA}}$ & $0,16 \pm 0,07^{\mathrm{aA}}$ & $0,19 \pm 0,10^{\mathrm{aA}}$ & $0,17 \pm 0,07^{\mathrm{aA}}$ & $0,21 \pm 0,08^{\mathrm{aA}}$ & $0,15 \pm 0,06^{\mathrm{aA}}$ \\
\hline 3 & 1,58 & $0,12 \pm 0,03^{\mathrm{bA}}$ & $0,12 \pm 0,01^{\mathrm{bA}}$ & $0,15 \pm 0,04^{\mathrm{abA}}$ & $0,11 \pm 0,02^{\mathrm{bA}}$ & $0,16 \pm 0,03^{\mathrm{bA}}$ & $0,18 \pm 0,03^{\mathrm{aA}}$ & $0,26 \pm 0,08^{\mathrm{aA}}$ & $0,29 \pm 0,09^{\mathrm{aA}}$ & $0,30 \pm 0,09^{\mathrm{aA}}$ \\
\hline 4 & 2,09 & $0,36 \pm 0,14^{\mathrm{aA}}$ & $0,90 \pm 0,60^{\mathrm{aA}}$ & $0,56 \pm 0,51^{\mathrm{aA}}$ & $0,56 \pm 0,27^{\mathrm{aA}}$ & $1,11 \pm 1,02^{\mathrm{aB}}$ & $0,32 \pm 0,05^{\mathrm{aA}}$ & $0,28 \pm 0,10^{\mathrm{aA}}$ & $0,61 \pm 0,37^{\mathrm{aA}}$ & $0,34 \pm 0,16^{\mathrm{aA}}$ \\
\hline 5 & 2,26 & $0,16 \pm 0,07^{\mathrm{aA}}$ & $0,31 \pm 0,14^{\mathrm{bA}}$ & $0,29 \pm 0,15^{\mathrm{aA}}$ & $0,21 \pm 0,06^{\mathrm{aA}}$ & $0,58 \pm 0,15^{\mathrm{aA}}$ & & & $0,22 \pm 0,07^{\mathrm{bA}}$ & $0,19 \pm 0,05^{\mathrm{aA}}$ \\
\hline 6 & 2,54 & & $0,19 \pm 0,04^{\mathrm{aA}}$ & $0,2 \pm 0,07^{\mathrm{aB}}$ & $0,17 \pm 0,01^{\mathrm{aA}}$ & & $0,14 \pm 0,02^{\mathrm{aA}}$ & & $0,15 \pm 0,04^{\mathrm{aA}}$ & \\
\hline 7 & 2,64 & $0,18 \pm 0,05^{\mathrm{aA}}$ & $0,32 \pm 0,10^{\mathrm{aA}}$ & $0,36 \pm 0,09^{\mathrm{aA}}$ & $0,19 \pm 0,07^{\mathrm{aA}}$ & $0,23 \pm 0,07^{\mathrm{aA}}$ & $0,39 \pm 0,13^{\mathrm{aB}}$ & & & \\
\hline 8 & 2,72 & $0,97 \pm 0,54^{\mathrm{aA}}$ & $1,53 \pm 0,38^{\mathrm{aA}}$ & $1,44 \pm 0,44^{\mathrm{aA}}$ & $0,96 \pm 0,41^{\mathrm{aC}}$ & $2,03 \pm 0,96^{\mathrm{aA}}$ & $1,92 \pm 1,01^{\mathrm{aB}}$ & $0,38 \pm 0,39^{\mathrm{aA}}$ & $0,54 \pm 0,16^{\mathrm{bA}}$ & $0,60 \pm 0,32^{\mathrm{bA}}$ \\
\hline 9 & 2,93 & & & & & & $0,12 \pm 0,01$ & & $0,12 \pm 0,01$ & \\
\hline 10 & 3,16 & $0,54 \pm 0,14^{\mathrm{aA}}$ & $0,69 \pm 0,10^{\mathrm{aA}}$ & $0,64 \pm 0,17^{\mathrm{aA}}$ & $0,55 \pm 0,07^{\mathrm{aA}}$ & $0,67 \pm 0,16^{\mathrm{aA}}$ & $0,67 \pm 0,15^{\mathrm{aA}}$ & $0,27 \pm 0,12^{\mathrm{bA}}$ & $0,29 \pm 0,10^{\mathrm{bA}}$ & $0,24 \pm 0,10^{\mathrm{bA}}$ \\
\hline 11 & 3,34 & $0,36 \pm 0,12^{\mathrm{aA}}$ & $0,46 \pm 0,06^{\mathrm{aA}}$ & $0,46 \pm 0,12^{\mathrm{aA}}$ & $0,4 \pm 0,07^{\mathrm{aA}}$ & $0,47 \pm 0,11^{\mathrm{aA}}$ & $0,43 \pm 0,07^{\mathrm{aA}}$ & $0,47 \pm 0,12^{\mathrm{aA}}$ & $0,56 \pm 0,07^{\mathrm{aA}}$ & $0,44 \pm 0,14^{\mathrm{aA}}$ \\
\hline 12 & 3,79 & $0,37 \pm 0,14^{\mathrm{aA}}$ & $0,43 \pm 0,13^{\mathrm{aA}}$ & $0,36 \pm 0,13^{\mathrm{aA}}$ & $0,46 \pm 0,07^{\mathrm{aA}}$ & $0,45 \pm 0,13^{\mathrm{aA}}$ & $0,35 \pm 0,09^{\mathrm{aA}}$ & $0,32 \pm 0,10^{\mathrm{aA}}$ & $0,47 \pm 0,11^{\mathrm{aA}}$ & $0,42 \pm 0,12^{\mathrm{aA}}$ \\
\hline 13 & 4,71 & $0,18 \pm 0,01^{\mathrm{aA}}$ & $0,16 \pm 0,00^{\mathrm{aA}}$ & & $0,17 \pm 0,01^{\mathrm{aA}}$ & $0,18 \pm 0,02^{\mathrm{aA}}$ & & & $0,17 \pm 0,01^{\mathrm{aA}}$ & \\
\hline 14 & 10,53 & $3,32 \pm 0,44^{\mathrm{aA}}$ & $4,28 \pm 1,28^{\mathrm{aA}}$ & $3,69 \pm 1,59^{\mathrm{abA}}$ & $3,28 \pm 0,42^{\mathrm{aA}}$ & $4,29 \pm 1,44^{\mathrm{aA}}$ & $3,22 \pm 1,13^{\mathrm{aA}}$ & $1,84 \pm 0,84^{\mathrm{bA}}$ & $2,88 \pm 1,05^{\mathrm{bA}}$ & $2,01 \pm 1,03^{\mathrm{bA}}$ \\
\hline 15 & 10,84 & $3,71 \pm 0,66^{\mathrm{aA}}$ & $3,44 \pm 1,30^{\mathrm{aA}}$ & $2,56 \pm 1,29^{\mathrm{abA}}$ & $3,31 \pm 0,64^{\mathrm{aA}}$ & $3,41 \pm 1,23^{\mathrm{aB}}$ & $2,17 \pm 0,85^{\mathrm{bA}}$ & $1,64 \pm 0,99^{\mathrm{bA}}$ & $2,28 \pm 0,91^{\mathrm{bA}}$ & $1,37 \pm 0,84^{\mathrm{bA}}$ \\
\hline 16 & 11,53 & $0,34 \pm 0,11^{\mathrm{abA}}$ & $0,32 \pm 0,16^{\mathrm{aA}}$ & $0,24 \pm 0,18^{\mathrm{aA}}$ & $0,3 \pm 0,09^{\mathrm{bA}}$ & $0,28 \pm 0,12^{\mathrm{aA}}$ & $0,21 \pm 0,08^{\mathrm{aA}}$ & $0,15 \pm 0,11^{\mathrm{bA}}$ & $0,25 \pm 0,11^{\mathrm{aA}}$ & $0,22 \pm 0,09^{\mathrm{aA}}$ \\
\hline 17 & 11,93 & $1,25 \pm 0,21^{\mathrm{aA}}$ & $1,75 \pm 0,63^{\mathrm{aA}}$ & $1,54 \pm 0,91^{\mathrm{aA}}$ & $1,22 \pm 0,22^{\mathrm{aA}}$ & $1,87 \pm 0,74^{\mathrm{aA}}$ & $1,38 \pm 0,54^{\mathrm{aA}}$ & $0,57 \pm 0,33^{\mathrm{aA}}$ & $1,06 \pm 0,35^{\mathrm{bA}}$ & $0,95 \pm 0,49^{\mathrm{aA}}$ \\
\hline 18 & 12,33 & $0,11 \pm 0,02^{\mathrm{aA}}$ & $0,14 \pm 0,02^{\mathrm{abA}}$ & $0,13 \pm 0,07^{\mathrm{aA}}$ & $0,11 \pm 0,02^{\mathrm{aA}}$ & $0,13 \pm 0,04^{\mathrm{aA}}$ & $0,11 \pm 0,03^{\mathrm{aA}}$ & $0,08 \pm 0,05^{\mathrm{aA}}$ & $0,08 \pm 0,02^{\mathrm{bA}}$ & \\
\hline 19 & 15,27 & $0,24 \pm 0,08^{\mathrm{aA}}$ & $0,24 \pm 0,11^{\mathrm{aA}}$ & $0,16 \pm 0,07^{\mathrm{abA}}$ & $0,27 \pm 0,16^{\mathrm{aA}}$ & $0,20 \pm 0,06^{\mathrm{aA}}$ & $0,15 \pm 0,05^{\mathrm{aA}}$ & $0,16 \pm 0,05^{\mathrm{aA}}$ & $0,27 \pm 0,09^{\mathrm{aA}}$ & $0,34 \pm 0,26^{\mathrm{aA}}$ \\
\hline 20 & 15,76 & $0,52 \pm 0,07^{\mathrm{abA}}$ & $0,65 \pm 0,24^{\mathrm{aA}}$ & $0,57 \pm 0,39^{\mathrm{abA}}$ & $0,48 \pm 0,09^{\mathrm{bA}}$ & $0,65 \pm 0,23^{\mathrm{aA}}$ & $0,50 \pm 0,26^{\mathrm{bA}}$ & $0,22 \pm 0,11^{\mathrm{bA}}$ & $0,35 \pm 0,12^{\mathrm{bA}}$ & $0,29 \pm 0,14^{\mathrm{bA}}$ \\
\hline 21 & 16,74 & & & & $0,24 \pm 0,06^{\mathrm{aA}}$ & & & $0,12 \pm 0,00^{\mathrm{aA}}$ & $0,15 \pm 0,04^{\mathrm{aA}}$ & $0,34 \pm 0,26^{\mathrm{aA}}$ \\
\hline 22 & 18,25 & $0,85 \pm 0,20^{\mathrm{aA}}$ & $0,77 \pm 0,35^{\mathrm{aA}}$ & $0,59 \pm 0,49^{\mathrm{aA}}$ & $0,68 \pm 0,21^{\mathrm{aA}}$ & $0,74 \pm 0,29^{\mathrm{aA}}$ & $0,52 \pm 0,30^{\mathrm{aA}}$ & $0,27 \pm 0,23^{\mathrm{bA}}$ & $0,35 \pm 0,17^{\mathrm{bA}}$ & $0,23 \pm 0,15^{\mathrm{aA}}$ \\
\hline 23 & 22,18 & & $0,13 \pm 0,01^{\mathrm{aA}}$ & $0,17 \pm 0,03^{\mathrm{aA}}$ & & & & & & \\
\hline 24 & 26,48 & $0,5 \pm 0,13^{\mathrm{aA}}$ & $0,30 \pm 0,14^{\mathrm{aA}}$ & $0,17 \pm 0,10^{\mathrm{bA}}$ & $0,59 \pm 0,30^{\mathrm{aA}}$ & $0,29 \pm 0,11^{\mathrm{aA}}$ & $0,18 \pm 0,09^{\mathrm{bB}}$ & $0,42 \pm 0,19^{\mathrm{aA}}$ & $0,62 \pm 0,32^{\mathrm{aA}}$ & $0,56 \pm 0,63^{\mathrm{aA}}$ \\
\hline 25 & 27,73 & & & $0,1 \pm 0,03^{\mathrm{aA}}$ & $0,1 \pm 0,01^{\mathrm{aA}}$ & $0,1 \pm 0,05^{\mathrm{aA}}$ & & & & $0,13 \pm 0,05^{\mathrm{aA}}$ \\
\hline 26 & 27,99 & & & & & & & $0,09 \pm 0,05^{\mathrm{bA}}$ & $0,05 \pm 0,03^{\mathrm{bA}}$ & $0,16 \pm 0,08^{\mathrm{aA}}$ \\
\hline 27 & 29,36 & $0,04 \pm 0,02^{\mathrm{bA}}$ & & & $0,07 \pm 0,05^{\mathrm{bA}}$ & & & $0,39 \pm 0,28^{\mathrm{Aa}}$ & $0,27 \pm 0,13^{\mathrm{aB}}$ & $0,81 \pm 0,43^{\mathrm{aA}}$ \\
\hline \multirow[t]{4}{*}{28} & 33,12 & & & & & & & $0,11 \pm 0,05^{\mathrm{aA}}$ & $0,13 \pm 0,05^{\mathrm{aA}}$ & $0,19 \pm 0,09^{\mathrm{aA}}$ \\
\hline & Flavonóis & $10,10 \pm 1,56^{\mathrm{aA}}$ & $11,34 \pm 3,92^{\mathrm{aA}}$ & $9,34 \pm 4,78^{\mathrm{aA}}$ & $9,39 \pm 1,53^{\mathrm{abA}}$ & $11,40 \pm 3,92^{\mathrm{aA}}$ & $8,06 \pm 3,17^{\mathrm{aA}}$ & $4,16 \pm 2,79^{\mathrm{bA}}$ & $7,19 \pm 2,56^{\mathrm{aA}}$ & $4,99 \pm 2,69^{\mathrm{aA}}$ \\
\hline & Isoflavonoides & $0,66 \pm 0,34^{\mathrm{aA}}$ & $0,51 \pm 0,29^{\mathrm{aAB}}$ & $0,25 \pm 0,19^{\mathrm{bB}}$ & $0,93 \pm 0,58^{\mathrm{aA}}$ & $0,46 \pm 0,18^{\mathrm{aAB}}$ & $0,26 \pm 0,18^{\mathrm{bB}}$ & $0,97 \pm 0,49^{\mathrm{aA}}$ & $1,21 \pm 0,57^{\mathrm{aA}}$ & $2,01 \pm 1,49^{\mathrm{aA}}$ \\
\hline & Der.cinâmicos & $2,78 \pm 0,65^{\mathrm{aB}}$ & $4,41 \pm 1,12^{\mathrm{aA}}$ & $3,76 \pm 1,07^{\mathrm{aAB}}$ & $3,41 \pm 0,91^{\mathrm{abB}}$ & $5,25 \pm 1,92^{\mathrm{aA}}$ & $3,67 \pm 1,53^{\mathrm{aAB}}$ & $2,05 \pm 0,60^{\mathrm{bA}}$ & $3,39 \pm 0,91^{\mathrm{bA}}$ & $2,56 \pm 0,83^{\mathrm{bA}}$ \\
\hline
\end{tabular}


Tabela 5:Constituintes da variedade de soja CD202RR, em mg/g, para as câmaras Controle, UV- (ausência parcial de luz UV) e UV+ (Acréscimo de luz UV). Valores médios para cada constituinte em cada estádio. Letras minúsculas indicam se há diferença entre os estádios vegetativos. Letras maiúsculas indicam se há diferenças entre as câmaras.

\begin{tabular}{|c|c|c|c|c|c|c|c|c|c|c|}
\hline & \multirow{2}{*}{$\operatorname{Tr}(\min )$} & \multicolumn{3}{|c|}{ Controle } & \multicolumn{3}{|c|}{ UV- } & \multicolumn{3}{|c|}{$\mathrm{UV+}$} \\
\hline & & V3 & $\mathrm{V} 4$ & V5 & V3 & $\mathrm{V} 4$ & V5 & V3 & $\mathrm{V} 4$ & V5 \\
\hline 1 & 1,39 & & & & & & & $0,17 \pm 0,04^{\mathrm{aA}}$ & $0,15 \pm 0,07^{\mathrm{aA}}$ & $0,2 \pm 0,04^{\mathrm{aA}}$ \\
\hline 2 & 1,43 & $0,12 \pm 0,03^{\mathrm{aA}}$ & $0,14 \pm 0,04^{\mathrm{aA}}$ & $0,15 \pm 0,03^{\mathrm{aA}}$ & & $0,12 \pm 0,01^{\mathrm{aA}}$ & $0,13 \pm 0,01^{\mathrm{aA}}$ & $0,13 \pm 0,02^{\mathrm{aA}}$ & $0,13 \pm 0,06^{\mathrm{aA}}$ & $0,14 \pm 0,04^{\mathrm{aA}}$ \\
\hline 3 & 1,58 & $0,11 \pm 0,03^{\mathrm{bA}}$ & $0,13 \pm 0,03^{\mathrm{bA}}$ & $0,13 \pm 0,3^{\mathrm{bA}}$ & $0,13 \pm 0,06^{\mathrm{bA}}$ & $0,12 \pm 0,03^{\mathrm{bA}}$ & $0,13 \pm 0,03^{\mathrm{bA}}$ & $0,20 \pm 0,03^{\mathrm{aA}}$ & $0,24 \pm 0,05^{\mathrm{aA}}$ & $0,23 \pm 0,03^{\mathrm{aA}}$ \\
\hline 4 & 2,08 & $0,57 \pm 0,45^{\mathrm{aA}}$ & $1,37 \pm 1,43^{\mathrm{abB}}$ & $0,49 \pm 0,29^{\mathrm{aA}}$ & $0,46 \pm 0,19^{\mathrm{aA}}$ & $0,85 \pm 0,72^{\mathrm{bA}}$ & $0,64 \pm 0,42^{\mathrm{aA}}$ & $0,81 \pm 0,99^{\mathrm{aA}}$ & $0,33 \pm 0,17^{\mathrm{bA}}$ & $0,31 \pm 0,09^{a A}$ \\
\hline 5 & 2,27 & $0,21 \pm 0,07^{\mathrm{bB}}$ & $0,63 \pm 0,27^{\mathrm{abB}}$ & $0,19 \pm 0,09^{\mathrm{aA}}$ & $0,17 \pm 0,01^{\mathrm{bA}}$ & $0,35 \pm 0,12^{\mathrm{bA}}$ & $0,20 \pm 0,05^{\mathrm{aA}}$ & $0,63 \pm 0,19^{a B}$ & $0,15 \pm 0,02^{\mathrm{bA}}$ & $0,16 \pm 0,02^{\mathrm{aA}}$ \\
\hline 6 & 2,54 & $0,12 \pm 0,03^{\mathrm{bB}}$ & $0,28 \pm 0,05^{\mathrm{aA}}$ & $0,14 \pm 0,01^{\mathrm{abB}}$ & $0,13 \pm 0,02^{\mathrm{bB}}$ & $0,19 \pm 0,04^{\mathrm{bA}}$ & $0,18 \pm 0,04^{\mathrm{aA}}$ & $0,29 \pm 0,04^{\mathrm{aA}}$ & $0,1 \pm 0,00^{\mathrm{cB}}$ & $0,1 \pm 0,01^{\mathrm{bA}}$ \\
\hline 7 & 2,64 & $0,33 \pm 0,03^{\mathrm{aA}}$ & $0,39 \pm 0,11^{\mathrm{aA}}$ & $0,28 \pm 0,15^{\mathrm{aA}}$ & $0,36 \pm 0,05^{\mathrm{aA}}$ & $0,52 \pm 0,10^{\mathrm{aA}}$ & $0,33 \pm 0,05^{\mathrm{aA}}$ & & & $0,1 \pm 0,01^{\mathrm{aA}}$ \\
\hline 8 & 2,72 & $1,43 \pm 0,54^{\mathrm{aA}}$ & $1,38 \pm 0,55^{\mathrm{bA}}$ & $1,62 \pm 0,66^{\mathrm{bA}}$ & $2,04 \pm 0,41^{\mathrm{aA}}$ & $2,23 \pm 0,51^{\mathrm{aA}}$ & $2,57 \pm 1,18^{\mathrm{aA}}$ & $0,54 \pm 0,32^{\mathrm{bA}}$ & $0,38 \pm 0,24^{\mathrm{cA}}$ & $0,62 \pm 0,28^{\mathrm{cA}}$ \\
\hline 9 & 2,94 & $0,12 \pm 0,01^{\mathrm{aA}}$ & $0,11 \pm 0,01^{\mathrm{aA}}$ & & $0,11 \pm 0,00^{\mathrm{aA}}$ & $0,1 \pm 0,00^{\mathrm{aA}}$ & $0,13 \pm 0,02^{\mathrm{aA}}$ & $0,15 \pm, 0,03^{\mathrm{aA}}$ & & \\
\hline 10 & 3,17 & $0,67 \pm 0,20^{\mathrm{aA}}$ & $0,69 \pm 0,20^{\mathrm{aA}}$ & $0,72 \pm 0,20^{\mathrm{aA}}$ & $0,61 \pm 0,19^{\mathrm{aA}}$ & $0,75 \pm 0,10^{\mathrm{aA}}$ & $0,77 \pm 0,18^{\mathrm{aA}}$ & $0,33 \pm 0,21^{\mathrm{bA}}$ & $0,29 \pm 0,12^{\mathrm{bA}}$ & $0,26 \pm 0,06^{\mathrm{bA}}$ \\
\hline 11 & 3,34 & $0,38 \pm 0,15^{\mathrm{abA}}$ & $0,47 \pm 0,07^{\mathrm{aA}}$ & $0,47 \pm 0,07^{\mathrm{aA}}$ & $0,33 \pm 0,16^{\mathrm{bA}}$ & $0,43 \pm 0,09^{\mathrm{aA}}$ & $0,47 \pm 0,10^{\mathrm{aA}}$ & $0,5 \pm 0,13^{\mathrm{aA}}$ & $0,45 \pm 0,16^{\mathrm{aA}}$ & $0,46 \pm 0,07^{\mathrm{aA}}$ \\
\hline 12 & 3,79 & $0,51 \pm 0,12^{\mathrm{aA}}$ & $0,40 \pm 0,17^{\mathrm{aA}}$ & $0,35 \pm 0,10^{\mathrm{aA}}$ & $0,5 \pm 0,10^{\mathrm{aA}}$ & $0,42 \pm 0,13^{\mathrm{aA}}$ & $0,39 \pm 0,13^{\mathrm{aA}}$ & $0,47 \pm 0,23^{\mathrm{aA}}$ & $0,40 \pm 0,15^{\mathrm{aA}}$ & $0,40 \pm 0,10^{\mathrm{aA}}$ \\
\hline 13 & 4,71 & $0,19 \pm 0,04^{\mathrm{aA}}$ & $0,17 \pm 0,01^{\mathrm{aA}}$ & & $0,23 \pm 0,02^{\mathrm{aA}}$ & & & $0,21 \pm 0,02^{\mathrm{aA}}$ & $0,16 \pm 0,01^{\mathrm{aA}}$ & \\
\hline 14 & 10,53 & $4,44 \pm 0,88^{\mathrm{aA}}$ & $4,11 \pm 1,74^{\mathrm{aA}}$ & $3,89 \pm 1,33^{\mathrm{aA}}$ & $4,38 \pm 0,56^{\mathrm{aA}}$ & $3,97 \pm 1,09^{\mathrm{aA}}$ & $4,00 \pm 1,08^{\mathrm{aA}}$ & $2,45 \pm 1,05^{\mathrm{bA}}$ & $2,87 \pm 0,99^{\mathrm{aA}}$ & $2,67 \pm 0,91^{\mathrm{aA}}$ \\
\hline 15 & 10,84 & $4,05 \pm 0,82^{\mathrm{aA}}$ & $3,61 \pm 2,15^{\mathrm{aA}}$ & $2,95 \pm 1,17^{\mathrm{aA}}$ & $3,92 \pm 0,79^{\mathrm{aA}}$ & $3,47 \pm 1,24^{\mathrm{aA}}$ & $2,98 \pm 1,12^{\mathrm{aA}}$ & $2,18 \pm 1,19^{\mathrm{bA}}$ & $2,23 \pm 0,82^{\mathrm{aA}}$ & $1,84 \pm 0,72^{\mathrm{aA}}$ \\
\hline 16 & 11,54 & $0,36 \pm 0,14^{\mathrm{aA}}$ & $0,35 \pm 0,27^{\mathrm{aA}}$ & $0,24 \pm 0,10^{\mathrm{aA}}$ & $0,41 \pm 0,13^{\mathrm{aA}}$ & $0,28 \pm 0,15^{\mathrm{aA}}$ & $0,25 \pm 0,09^{\mathrm{aA}}$ & $0,26 \pm 0,20^{\mathrm{aA}}$ & $0,26 \pm 0,13^{\mathrm{aA}}$ & $0,25 \pm 0,10^{\mathrm{aA}}$ \\
\hline 17 & 11,94 & $1,75 \pm 0,53^{\mathrm{aA}}$ & $1,54 \pm 0,74^{\mathrm{aA}}$ & $1,67 \pm 0,69^{\mathrm{aA}}$ & $1,67 \pm 0,38^{\mathrm{aA}}$ & $1,49 \pm 0,49^{\mathrm{aA}}$ & $1,79 \pm 0,62^{\mathrm{aA}}$ & $0,68 \pm 0,46^{\mathrm{bA}}$ & $1,05 \pm 0,35^{\mathrm{aA}}$ & $1,20 \pm 0,38^{\mathrm{aA}}$ \\
\hline 18 & 12,34 & $0,15 \pm 0,05^{\mathrm{aA}}$ & $0,12 \pm 0,06^{\mathrm{aA}}$ & $0,14 \pm 0,06^{\mathrm{aA}}$ & $0,13 \pm 0,03^{\mathrm{aA}}$ & $0,11 \pm 0,04^{\mathrm{aA}}$ & $0,14 \pm 0,06^{\mathrm{aA}}$ & $0,11 \pm 0,02^{\mathrm{aA}}$ & $0,1 \pm 0,02^{\mathrm{aA}}$ & $0,1 \pm 0,03^{\mathrm{aA}}$ \\
\hline 19 & 15,28 & $0,25 \pm 0,11^{\mathrm{aA}}$ & $0,23 \pm 0,11^{\mathrm{aA}}$ & $0,13 \pm 0,04^{\mathrm{bA}}$ & $0,24 \pm 0,09^{\mathrm{aA}}$ & $0,21 \pm 0,11^{\mathrm{aA}}$ & $0,12 \pm 0,05^{\mathrm{bA}}$ & $0,24 \pm 0,10^{\mathrm{aA}}$ & $0,25 \pm 0,11^{\mathrm{aA}}$ & $0,30 \pm 0,13^{\mathrm{aA}}$ \\
\hline 20 & 15,76 & $0,64 \pm 0,14^{\mathrm{aA}}$ & $0,59 \pm 0,31^{\mathrm{aA}}$ & $0,80 \pm 0,32^{\mathrm{aA}}$ & $0,62 \pm 0,14^{\mathrm{aA}}$ & $0,57 \pm 0,21^{\mathrm{aA}}$ & $0,66 \pm 0,30^{\mathrm{aA}}$ & $0,31 \pm 0,16^{\mathrm{bA}}$ & $0,35 \pm 0,12^{\mathrm{aA}}$ & $0,3 \pm 0,12^{\mathrm{bA}}$ \\
\hline 21 & 16,76 & & & & & & & $0,27 \pm 0,04^{\mathrm{aA}}$ & $0,17 \pm 0,05^{\mathrm{bA}}$ & $0,26 \pm 0,05^{\mathrm{aA}}$ \\
\hline 22 & 18,26 & $0,84 \pm 0,27^{\mathrm{aA}}$ & $0,73 \pm 0,52^{\mathrm{aA}}$ & $0,74 \pm 0,42^{\mathrm{aA}}$ & $0,8 \pm 0,29^{\mathrm{aA}}$ & $0,70 \pm 0,31^{\mathrm{aA}}$ & $0,71 \pm 0,40^{\mathrm{aA}}$ & $0,34 \pm 0,20^{\mathrm{bA}}$ & $0,34 \pm 0,16^{\mathrm{aA}}$ & $0,29 \pm 0,14^{\mathrm{bA}}$ \\
\hline 23 & 22,15 & $0,14 \pm 0,03^{\mathrm{aA}}$ & $0,12 \pm 0,00^{\mathrm{aA}}$ & $0,21 \pm 0,07^{\mathrm{aA}}$ & $0,13 \pm 0,02^{\mathrm{aA}}$ & $0,15 \pm 0,00^{\mathrm{aA}}$ & $0,16 \pm 0,03^{\mathrm{aA}}$ & & & \\
\hline 24 & 26,48 & $0,46 \pm 0,22^{\mathrm{aA}}$ & $0,32 \pm 0,22^{\mathrm{bA}}$ & $0,17 \pm 0,06^{\mathrm{bA}}$ & $0,46 \pm 0,13^{\mathrm{aA}}$ & $0,27 \pm 0,15^{\mathrm{bA}}$ & $0,17 \pm 0,08^{\mathrm{bA}}$ & $0,66 \pm 0,41^{\mathrm{aA}}$ & $0,74 \pm 0,29^{\mathrm{aA}}$ & $0,78 \pm 0,34^{\mathrm{aA}}$ \\
\hline 25 & 27,73 & $0,09 \pm 0,01^{\mathrm{aA}}$ & $0,15 \pm 0,05^{\mathrm{aA}}$ & $0,1 \pm 0,04^{\mathrm{aA}}$ & $0,14 \pm 0,05^{\mathrm{aA}}$ & $0,12 \pm 0,01^{\mathrm{aA}}$ & & $0,16 \pm 0,09^{\mathrm{aA}}$ & $0,11 \pm 0,02^{\mathrm{aA}}$ & $0,12 \pm 0,04^{\mathrm{aA}}$ \\
\hline 26 & 28 & & & & & & & $0,09 \pm 0,05^{\mathrm{aA}}$ & $0,13 \pm 0,07^{\mathrm{aA}}$ & $0,10 \pm 0,05^{\mathrm{aA}}$ \\
\hline 27 & 29,36 & $0,09 \pm 0,01^{\mathrm{aA}}$ & $0,11 \pm 0,04^{\mathrm{aA}}$ & & & $0,07 \pm 0,06^{\mathrm{aA}}$ & & $0,31 \pm 0,32^{\mathrm{aA}}$ & $0,65 \pm 0,45^{\mathrm{aA}}$ & $0,57 \pm 0,20^{\mathrm{aA}}$ \\
\hline \multirow[t]{4}{*}{28} & 33,13 & & & & & & & $0,15 \pm 0,09^{\mathrm{aA}}$ & $0,22 \pm 0,11^{\mathrm{aA}}$ & $0,18 \pm 0,07^{\mathrm{aA}}$ \\
\hline & Flavonóis & $12,28 \pm 2,65^{\mathrm{aA}}$ & $11,13 \pm 5,69^{\mathrm{aA}}$ & $10,37 \pm 4,26^{\mathrm{aA}}$ & $12,05 \pm 1,91^{\mathrm{aA}}$ & $10,66 \pm 3,40^{\mathrm{aA}}$ & $10,63 \pm 3,66^{\mathrm{aA}}$ & $6,46 \pm 3,09^{\mathrm{bA}}$ & $7,18 \pm 2,41^{\mathrm{aA}}$ & $6,72 \pm 2,33^{\mathrm{aA}}$ \\
\hline & Isoflavonoides & $0,73 \pm 0,33^{\mathrm{aA}}$ & $0,55 \pm 0,36^{\mathrm{abAB}}$ & $0,25 \pm 0,13^{\mathrm{bB}}$ & $0,70 \pm 0,20^{\mathrm{aA}}$ & $0,45 \pm 0,28^{\mathrm{bAB}}$ & $0,25 \pm 0,14^{\mathrm{bB}}$ & $1,21 \pm 0,73^{\mathrm{aA}}$ & $1,98 \pm 0,48^{\mathrm{aA}}$ & $2,16 \pm 0,61^{\mathrm{aA}}$ \\
\hline & Der.cinâmicos & $4,10 \pm 1,33^{\mathrm{abA}}$ & $4,95 \pm 2,63^{\mathrm{aA}}$ & $3,97 \pm 0,96^{\mathrm{aA}}$ & $4,39 \pm 0,67^{\mathrm{bA}}$ & $5,14 \pm 1,30^{\mathrm{aA}}$ & $5,17 \pm 1,51^{\mathrm{aA}}$ & $3,35 \pm 2,30^{\mathrm{aA}}$ & $2,45 \pm 0,91^{\mathrm{bA}}$ & $2,66 \pm 0,48^{\mathrm{bA}}$ \\
\hline
\end{tabular}


Quando comparados os conteúdos de flavonóis e de derivados cinâmicos nos estádios para uma mesma câmara, não há diferença significativa nos conteúdos dessas duas classes de substâncias fenólicas ao longo do desenvolvimento da planta para o cultivar CD202RR. O cultivar CD202 apresentou o mesmo comportamento com relação ao conteúdo de flavonóis, mas na câmara Controle foi observado que há um aumento no conteúdo de derivados do ácido cinâmico ao longo do desenvolvimento da soja, ou seja o estádio V3 é o que apresentou as menores concentrações dessa classe de substâncias. Também é possível observar que na câmara Controle há diminuição significativa do conteúdo de isoflavonas ao longo do desenvolvimento da soja, para ambos os cultivares, com o estádio V5 apresentando o menor conteúdo de isoflavonas quando comparado aos outros dois estádios.

Para a síntese nos frutos, os genes responsáveis pela expressão e acúmulo das isoflavonas são a CHS7, CHS8 e Isoflavona Sintase II (DHAUBHADEL et al. 2007). Estes genes também são resposáveis pela indução da produção das isoflanonas nas folhas de soja e vagens (ZAVALA et al., 2015). Vale lembrar que durante o desenvolvimento dos frutos, todo o substrato necessário para crescimento vem das folhas, uma vez que os fotoassimilados são produzidos nelas, ou seja, o mecanismo fonte e dreno (TAIZ \& ZEIGER, 2009). Quando a planta de soja é leisonada ou sofre de algum estresse abiotico, necessariamente não há um aumento da produção de isoflavonas nas sementes, é necessário que o dano seja direcionado às sementes (ZAVALA et al., 2015).

Considerando-se os conteúdos de substâncias fenólicas no desenvolvimento com o efeito do tratamento, nessa mesma figura é possível notar que no tratamento UV- as plantas apresentaram diferenças entre os estádios, mas que seguiram o comportamento observado na câmara Controle. Para o tratamento UV+ pode ser observado que os conteúdos de isoflavonas não diferiram entre os estádios de desenvolvimento, ou seja, não foi observada a diminuição gradual desses conteúdos nos estádios V4 e V5 como ocorreu na câmara Controle. Esse resultado sugere o efeito do tratamento na síntese e acúmulo dessa classe de substâncias (Figura 12). 

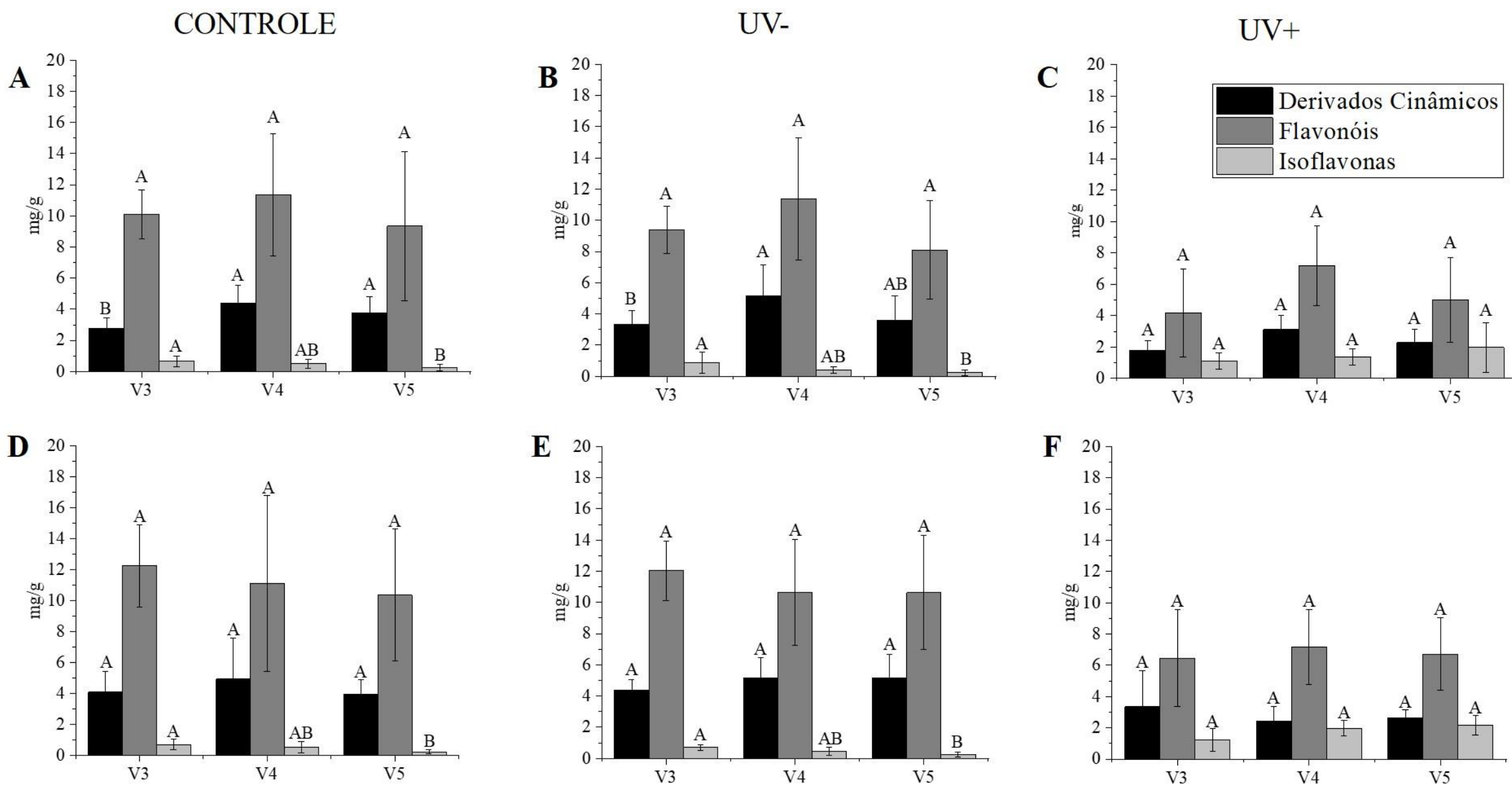

Figura 12. Conteúdos de substâncias fenólicas agrupadas nas classes derivados cinâmicos, flavonoides e isoflavonoides ao longo do desenvolvimento de Glicine max cultivares CD202 (A, B e C) e CD202RR (D, E e F) nos diferentes tratamentos: Controle, UV+ e UV-. Para cada câmara, letras diferentes indicam diferenças estatísticas entre os estádios $\mathrm{p}<0,05$. 
Para o efeito do tratamento, os conteúdos de substâncias fenólicas apresentado por cada estádio nos diferentes tratamentos (Controle, UV+e UV-) foram comparados entre si (Figura 13). Há uma tendência à redução dos conteúdos de flavonóis quando comparados os tratamentos Controle e UV+, entretanto apenas o estágio V3, de ambos os cultivares, foram observadas diferenças significativas para essa redução (Figura 13 - A e D). Com relação aos conteúdos de derivados do ácido cinâmico, houve redução significativa nos conteúdos dessas substâncias nas plantas expostas ao aumento de radiação UV. O contrário foi observado para as isoflavonas, que aumentaram em conteúdo no tratamento UV+. Nos estádios V4 e V5 podemos notar diferenças significativas quanto ao conteúdo destas substâncias, onde os menores valores são observados no Controle, seguidos pela câmara UV- e os maiores conteúdos de isoflavonas ocorrendo nas plantas cultivadas na câmara UV+. O estádio V5 representa o maior período de tempo que a planta foi submetida ao estresse por UV e, portanto, foi o estádio que apresentou alterações significativas quando comparado ao V3, estádio de menor período de exposição ao estresse.

Como uma forma de melhor entender o efeito dos tratamentos na composição e nos conteúdos dos constituintes fenólicos, foi realizada uma análise heatmap utilizando as 28 substâncias detectadas. Para essa análise, os valores são relativizados em relação aos encontrados no grupo controle e, com isso, aumento ou diminuição em conteúdo são facilmente observados (Figura 14). Na figura 14, a numeração utilizada para cada substância corresponde à mesma utilizada na tabela 3.

Como já mencionado, os cultivares apresentaram composição fenólica similar, assim como a mesma tendência de alterações nos conteúdos totais quando utilizamos o agrupamento desses constituintes nas três classes fenólicas: flavonóis, isoflavonas e derivados do ácido cinâmico. Analisando o conteúdo de cada constituinte podemos notar que as respostas individuais, de uma forma geral, também foram similares entre os cultivares (Figura 14). Além disso, embora os valores totais para as 3 classes de fenólicos avaliadas neste estudo tenham variado significativamente com o tratamento de acréscimo de UV+, alguns constituintes foram mais importantes para esse resultado. 

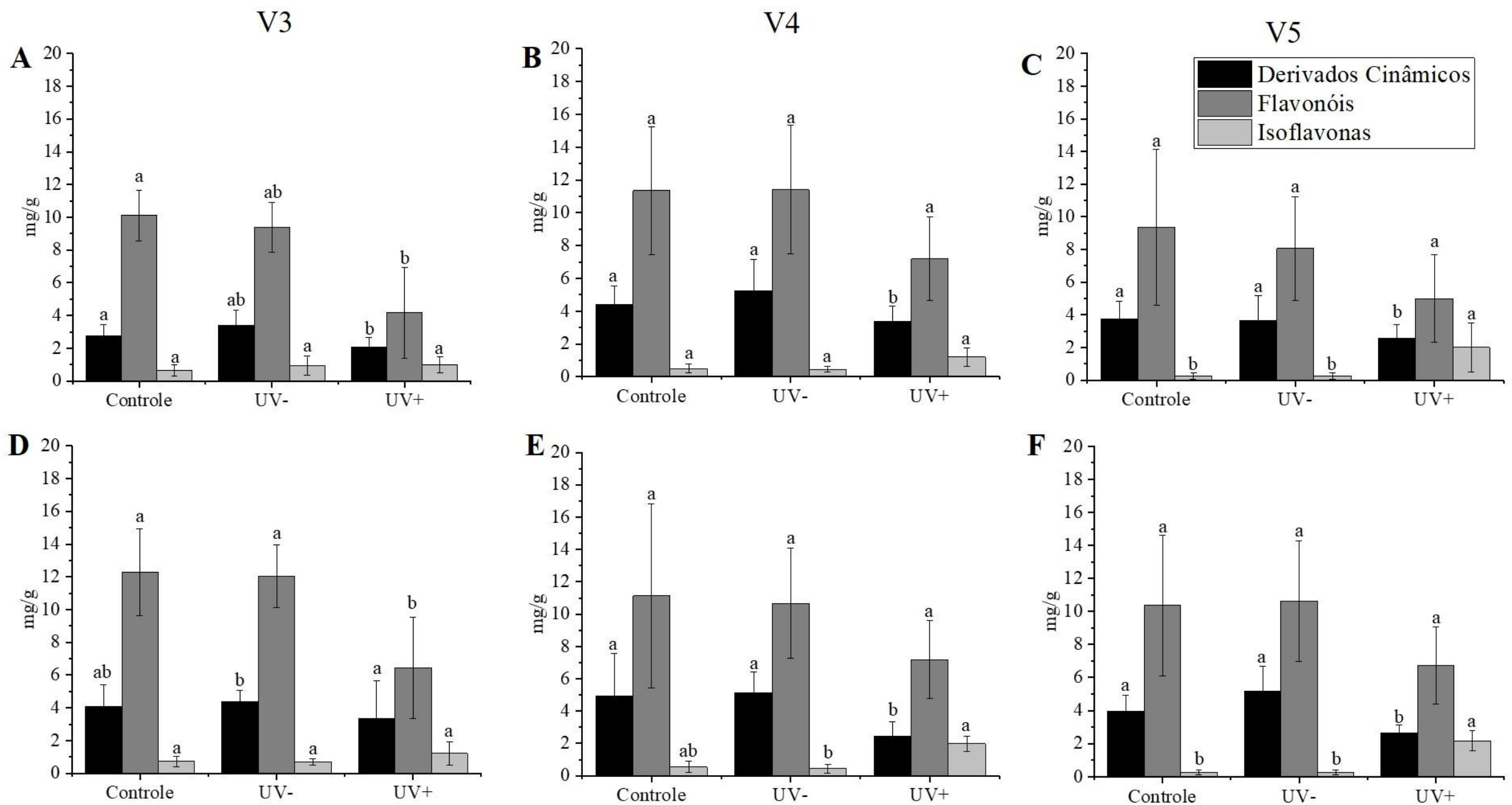

Figura 13. Conteúdos de substâncias fenólicas agrupadas nas classes de derivados cinâmicos, flavonoides e isoflavonoides de Glicine max cultivares CD202 (A, B e C) e CD202RR (D, E e F) nas diferentes câmaras. V3, V4 e V5 = estádios de desenvolvimento vegetativo. Para cada estádio, letras diferentes indicam diferenças estatísticas entre as câmaras $\mathrm{p}<0,05$. 


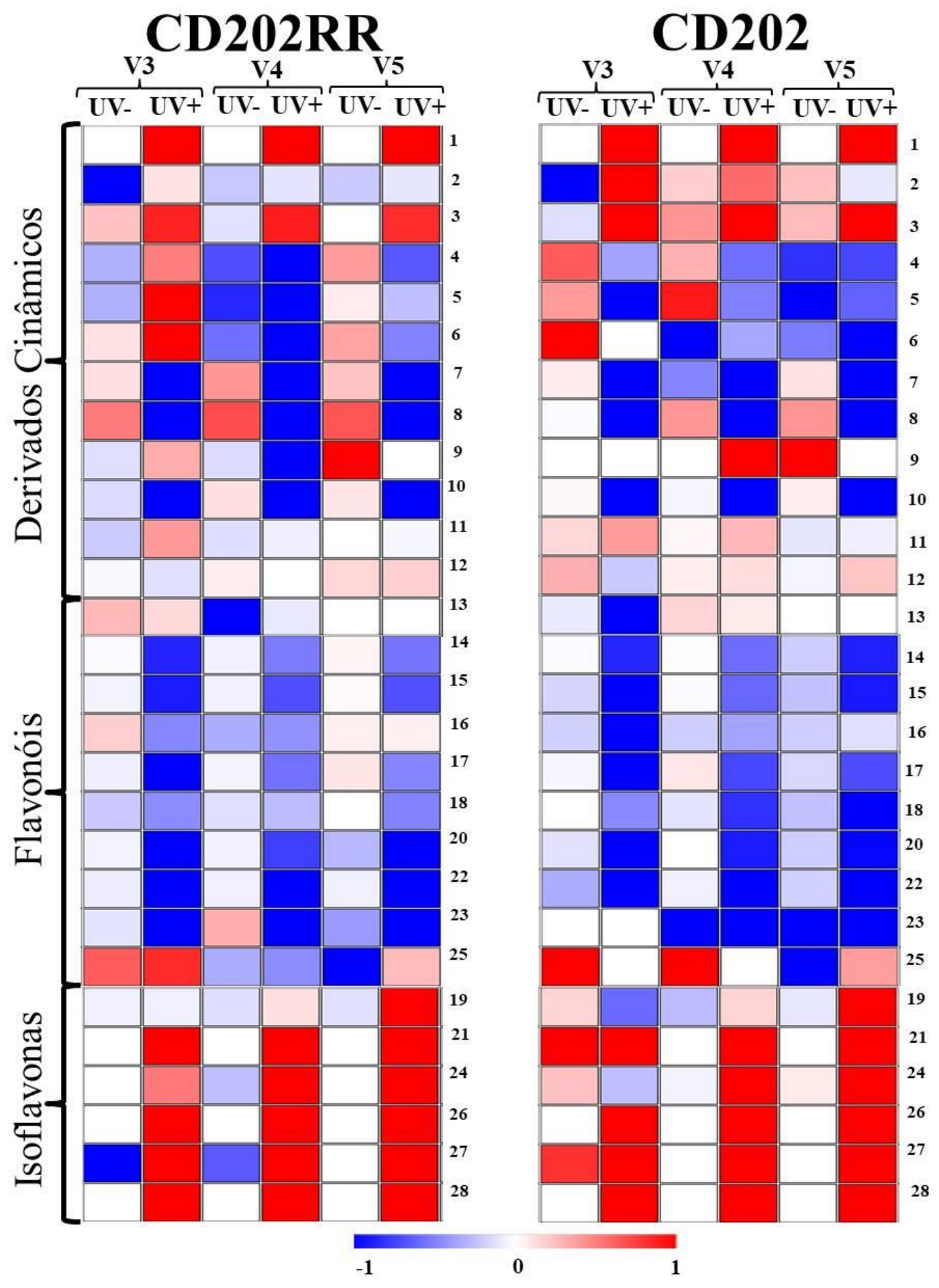

Figura 14: Heatmap das variações para os dois cultivares do estudo para as substâncias analisadas em CLAE-DAD. A: Heatmap obtido para o cultivar CD202RR. B: Heatmap obtido para o cultivar CD202. Diferentes tons de azul representam que os valores encontrados para o controle são maiores em relação aos demais tratamentos UV- e UV+. Os tons de vermelho representam que os valores encontrados para o controle são menores em relação aos demais tratamentos UV- e UV+. Números para as substâncias são os mesmos utilizados na Tabela 3. 
No geral, o perfil apresentado no heatmap, como já mencionado, é muito similar entre os cultivares. Para a câmara UV-, podemos notar, em todos os estádios, baixa coloração tanto vermelha quanto azul, o que demonstra a similaridade entre a câmara Controle e UV- para os conteúdos fenólicos. Portanto, a redução da radiação UV parece ser menos efetiva para causar alterações no metabolismo fenólico do que o aumento desta. Cabe ressaltar que a câmara UV- foi construída utilizando um filtro de acrílico posicionado de forma a cobrir superiormente às plantas, permanecendo as laterais da câmara sem proteção. Essa configuração reduziu a entrada de UV, mas não configurou a total ausência de radiação UV.

Observando os resultados para o cultivar CD202RR, para os derivados do ácido cinâmico, e embora o tratamento UV+ tenha refletido em aumento de conteúdo dos constituintes $\mathbf{1}$, $\mathbf{3}$, os constituintes $7, \mathbf{8}$ e $\mathbf{1 0}$ foram os mais afetados pelo tratamento, reduzindo em quantidade independentemente do estádio e do cultivar, entretanto nem todos os constituintes pertencentes a esta classe puderam ser identificados. Para o cultivar CD202, o aumento só foi verificado nos constituintes 1-3, 9 e 12 para os outros constituintes houve uma redução quando comparados ao Controle. Derivados de ácido cinâmico são conhecidos por aumentar quando a planta é submetida há algum fator de estresse (VIDOVIĆ et al., 2015b; ZAVALA et al., 2015; BANO et al., 2017).

Os constituintes 14-18, 20, 22 foram identificados como flavonóis glicosilados derivados de campferol e o constituinte $\mathbf{2 3}$ é derivado de apigenina, e são os constituintes majoritários em folhas dos cultivares analisados. Para esses constituintes novamente podemos notar que o tratamento UVfoi menos efetivo para expressar mudanças na síntese ou acúmulo dessas substâncias. Considerando o tratamento UV+, todos os flavonóis detectados apresentaram redução em relação ao Controle. Por outro lado, podemos observar que a isoflavonas $(\mathbf{1 9}, \mathbf{2 1}, \mathbf{2 4}, \mathbf{2 6 - 2 8})$ apresentaram aumento em conteúdo no tratamento UV+, em relação ao controle, e algumas dessas isoflavonas não foram identificadas no Controle (21, 26 e 28 no cultivar CD202RR e 21, 26-28 no cultivar CD202).

Para a produção natural de flavonoides, derivados cinâmicos e seus derivados, é necessário que haja exposição à radiação UV-B advinda naturalmente do ambiente. Os raios UV são necessários para a ativação dos genes responsáveis pela produção e acúmulo de compostos fenólicos. A maioria desses genes é regulada por radiação UV-B através da via UVR8, verificado em mutantes de Arabidopsis thaliana como o $u v r 8$, que é incapaz de acumular flavonoides e outros derivados fenólicos em resposta à radiação UV-B (DEMKURA \& BALLARÉ, 2012).

ZAVALA e colaboradores (2015) discorrem sobre os genes e enzimas responsáveis pelas vias de síntese dos compostos fenólicos. As flavanonas liquiritigenina e naringenina são os precurssores convertidos, respectivamente, em daidzeína e genisteína, pela ação da enzima isoflavona sintase (DEWICK, 2009). Entretanto, o acúmulo de isoflavonoides no desenvolvimento 
de sementes de soja também parece ser regulado pela ação das enzimas chalconas sintase CHS7, CHS8 e isoflavona sintase (DHAUBHADEL et al. 2007). Para a síntese de flavonóis, os contituintes majoritários detectados nas folhas de soja, o mesmo precursor naringenina é primeiro convertido em dihidroflavonol pela ação da enzima flavanona 3-hidroxilase, para então originar os flavonóis via a ação da enzima flavonol sintase (DEWICK, 2009). O material estudado apresentou derivados de genistina como majoritários entre as isoflavonas, indicando a importância da naringenina como precursor para síntese desses constituintes. Dessa forma, os constituintes identificados no presente trabalho, flavonóis derivados de campferol e isoflavonas derivadas da genisteína, utilizam o mesmo precurssor em suas vias de síntese. O decréscimo do conteúdo de flavonóis pode estar associado a um redirecionamento do precursor (flavanona) para a produção de isoflavonas, uma vez que o precursor é o mesmo para ambas as classe de flavonoides detectadas (DEWICK, 2009; ZAVALA et al. 2015; YUK et al., 2016b). Além disso, para alguns autores as isoflavonas são mais eficazes que outros flavonoides e fenilpropanoides (YUK et al., 2011a, 2016b) na proteção frente ao estresse promovido pela radiação UV (ZAVALA et al., 2015)(Figura 17 e 18).

Trabalhos como de ZAVALA et al. (2015) e YUK et al. (2016b) demonstram que há um aumento na quantidade de isoflavonas quando a planta é submetida a estresse. YUK e colaborades (2016b) induziram o acúmulo de isoflavonas ao expor as folhas de soja a uma grande quantidade de etileno. As plantas foram colocadas dentro de câmaras vedadas sob diferentes concentrações de etileno, e a cada $24 \mathrm{~h}$ as câmaras eram abertas. Este procedimento foi repetido por cinco dias. O tratamento com etileno mostrou que as folhas de sojas conseguem acumular grandes quantidades de isoflavonas, até cinco vezes mais do que o verificado para as sementes. $\mathrm{O}$ acúmulo de isoflavonas é comum nas leguminosas, entretanto, este parece ser acentuado quando a planta sofre algum estresse.

Já ZAVALA et al. (2015) observaram que sojas expostas à radiação UV apresentam acúmulo de isoflavonas e aumento de resistência a percevejos (Nezara viridula L. e Piezodorus guildinii W.). Quando os autores expuseram os cultivares Williams [grupo de maturação (MG) III], Dekalb CX458 (MG IV), Charata-76 (MG VII) e A5308 (MG V) a dois tratamentos, aumento de radiação UV e atenuação de radiação UV, observaram que os percevejos danificaram em maior intensidade as sementes e vagens dos cultivares crescidos com radiação UV atenuada. Os níveis de isoflavonas foram verificados tanto nas sementes quanto nas vagens, sendo verificado aumento de conteúdo de isoflanovas nas vagens que receberam radiação UV aumentada, corroborando com a preferência dos percevejos pelas vagens do tratamento atenuado. Para os autores, essa preferência diferenciada poderia representar uma estratégia para diminuir os danos causados pelos percevejos nas grandes culturas de soja, utilizando aumento de radiação UV como ferrenta. Entretanto outros 
danos, especialmente relacionados ao desenvolvimento da planta são visíveis quando a soja é tratada com aumento de radiação UV.

Essa eficácia demonstrada nos trabalhos de YUK et al. (2011a, 2016b) pode estar relacionada ao máximo de absoção das bandas I e II apresentadas pelos flavonoides em seus espectros de absorção UV-Visível. Em geral, as diferentes classes de flavonoides apresentam duas bandas caracterísitcas de absoção no espectro UV-Visível, a banda I entre 330-360 nm, que representa a absorção do anel B, e a banda II entre 250-280nm, correspondente à absorção do anel A (MARKHAM, 1982). Dessa forma, é possível diferenciar classes de flavonoides com base nos comprimentos máximos de absorção das duas bandas. Por exemplo, as isoflavonas, tem comprimento de absorção máximo da banda II em $260 \mathrm{~nm}$, com a banda I pouco representativa (devido à mudança espacial do anel aromático B) (Figura 15D); já as flavanonas tem absorção máxima na banda II em $280 \mathrm{~nm}$ e também baixa representação da banda I (devido a não conjugação das duplas ligações dos anéis A, C e B) (Figura 15A); as flavonas tem absorção máxima na banda I em 340 nm e banda II em 270 nm (Figura 15B); e os flavonóis apresentam absorção máxima em torno de $360 \mathrm{~nm}$ de banda I e $270 \mathrm{~nm}$ para a banda II (Figura 15C). Os padrões de substituição como glicosilação, prenilação e acilação podem alterar os espectros de absorção UV-Visivel, mas já se tem bem estabelecido um intervalo característico para cada classe de flavonoide (Tabela 6) (MARKHAM,1982).

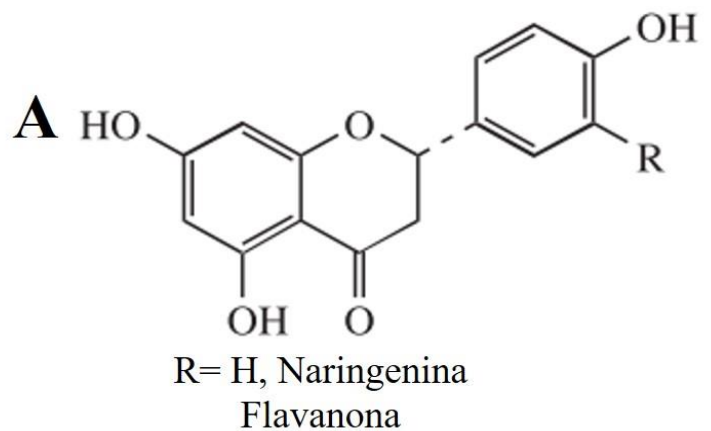

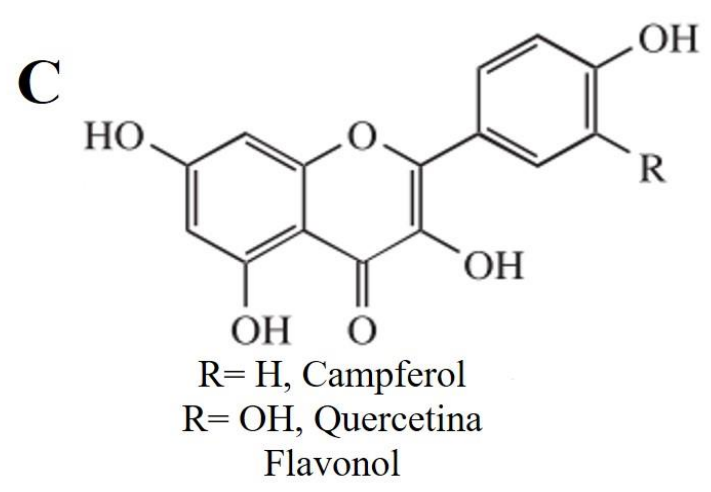<smiles>[R]c1cc(-c2cc(=O)c3c(O)cc(O)cc3o2)ccc1O</smiles>

$\mathrm{R}=\mathrm{H}$, Apigenina $\mathrm{R}=\mathrm{OH}$, Luteolina Flavona<smiles>[R]O[R3]([R])([H])[R]([R])c1cc(O)cc2occ(-c3ccc(O)cc3)c(=O)c12</smiles>

Figura 15: Estruturas básicas de algumas classes de flavonoides. A: Flavanona; B: Flavona; C: Flavonol e D: Isoflavona. Adaptado de DEWICK (2009). 
A radiação UV-B utilizada no interior da câmara UV+ neste estudo proporcionou o aumento de comprimentos de onda entre $280-315 \mathrm{~nm}$. A presença de maior contúdo de isoflavonas, classe que apresenta maximo de absorção em $260 \mathrm{~nm}$ pode significar uma maior proteção da soja à exposição ao UV, visto que os flavonóis identificados apresentaram espectros de UV-Vis com máximos de absorção entre 350-358 nm.

Tabela 6. Comprimentos máximos de absorção do espectro UV-Visível das diferentes classes de flavonoides.

\begin{tabular}{lll}
\hline Classes de flavonoides & Banda II (nm) & Banda I (nm) \\
\hline Chalconas & $220-270(\mathrm{bi})$ & $340-390$ \\
Flavanonas & $240-300$ & $300-330(\mathrm{om})$ \\
Dihidroflavonóis & $240-300$ & $300-330(\mathrm{om})$ \\
Flavonas & $240-280$ & $300-350$ \\
Flavonóis & $240-280$ & $350-390$ \\
Flavonóis (3-OH substituído) & $250-280$ & $330-360$ \\
Flavonóis (3-OH livre) & $250-280$ & $350-385$ \\
Isoflavonas & $240-275$ & $310-330(\mathrm{om})$ \\
Isoflavona (5-deoxi-6,7-dioxigenado) & $240-275$ & $310-330(\mathrm{om})$ com pico em 320 \\
Auronas & $220-270(\mathrm{bi})$ & $370-430$ \\
Antocaninas & $270-280$ & $465-560$ \\
\hline
\end{tabular}

*Dados adaptados de MARKHAM (1982) e CUNHA (2013); bi = baixa intensidade; om = ombro.

Outra estratégia utilizada foi a análise multivariada de componente principal (PCA) para a ideintifcação de grupos de amostras e quais as variáveis (constituintes) foram determinantes para a formação desses grupos. Na Figura 16 está apresentado o resultado obtido para a PCA gerada utilizando os dados de ambos os cultivares (CD202 e CD202RR) e as 28 substâncias identificadas por CLAE-EM: derivados cinâmicos (1-13), Flavonóis (14-18, 20, 22, 23 e 25) e isoflavonas (19, $21,24,26-28)$.

O resultado da PCA mostrou que 56\% da variabilidade encontrada nos dados podem ser explicados nos dois primeiros eixos. Na tabela 7 estão listados os valores das variâncias explicadas por essa análise e os valores esperados segundo o teste da vara quebrada, e podemos notar que os valores encontrados estão acima dos valores esperados, o que comprova a eficiência da análise. A tabela 8 mostra os coeficientes de correlação entre as variáveis e os eixos 1 e 2 . Valores de correlação próximos a 1 ou -1 indicam forte influência postiva ou negativa, respectivamente, da variável na distribuição das amostras em cada eixo. 
Na figura 16, podemos obervar que as amostras provenientes das câmaras Controle e UVaparecem agrupadas, para ambos os cultivares, no lado positivo do eixo 1, evidenciando, mais uma vez, a similaridade da composição fenólica das plantas crescidas nesses dois tratamentos. Para ambos os cultivares, as amostras provenientes do tratamento UV+ estão posicionadas no lado negativo do eixo 1, enquanto que a câmara UV+ agrupa, para ambos os cultivares, as amostras no lado negativo do eixo 2. Podemos abservar que os vetores mais influentes nessa separação (variáveis ou os constituintes fenólicos) são os flavonóis, relacionados positivamente com o eixo 1e as isoflavonas, relacionadas negativamente com o eixo 1 (Tabela 8). Isso mostra que o tratamento UV+ foi responsável pela diminuição nos conteúdos de flavonóis e aumento nos conteúdos de isoflavonas nas plantas crescidas sob influencia de maior radiação UV, independente do estádio de desenvlvimento analisado.

Tabela 7. Porcentagem de variância explicada e esperada (estimada pelo teste de vara quebrada) na análise de PCA para os cinco primeiros eixos, utilizando 28 variáveis e 253 amostras analisadas.

\begin{tabular}{cccc}
\hline Eixos & \% de variância & $\begin{array}{c}\text { \% de variância } \\
\text { acumulada }\end{array}$ & $\begin{array}{c}\text { \% de variância } \\
\text { esperada }\end{array}$ \\
\hline 1 & 38,517 & 38,517 & 14,026 \\
2 & 17,319 & 55,837 & 10,454 \\
3 & 7,604 & 63,441 & 8,668 \\
4 & 6,082 & 69,523 & 7,478 \\
5 & 5,334 & 74,857 & 6,585 \\
\hline
\end{tabular}

Tabela 8. Coeficientes de correlação entre as variáveis testadas e os eixos 1 e 2 . Números para as substâncias são os mesmos utilizados na Tabela 3.

\begin{tabular}{|c|c|c|c|c|c|c|c|c|}
\hline \multicolumn{3}{|c|}{ Derivados Cinâmicos } & \multicolumn{3}{|c|}{ Flavonóis } & \multicolumn{3}{|c|}{ Isoflavonas } \\
\hline Variável & Eixo 1 & Eixo 2 & Variável & Eixo 1 & Eixo 2 & Variável & Eixo 1 & Eixo 2 \\
\hline 1 & $-0,2008$ & 0,2527 & 14 & 0,2814 & 0,0578 & 19 & 0,0980 & 0,2903 \\
\hline 2 & $-0,1362$ & 0,0737 & 15 & 0,2824 & 0,0921 & 21 & $-0,0840$ & 0,3122 \\
\hline 3 & $-0,2114$ & 0,1525 & 16 & 0,2282 & 0,1553 & 24 & $-0,0213$ & 0,3606 \\
\hline 4 & 0,1868 & 0,1956 & 17 & 0,2580 & 0,0590 & 26 & $-0,1870$ & 0,2602 \\
\hline 5 & 0,1562 & 0,2470 & 18 & 0,2658 & 0,0065 & 27 & $-0,2009$ & 0,2232 \\
\hline 6 & 0,1708 & 0,2188 & 20 & 0,2738 & 0,0569 & 28 & $-0,1637$ & 0,2786 \\
\hline 7 & 0,0192 & $-0,1681$ & 22 & 0,2788 & 0,0411 & & & \\
\hline 8 & 0,2191 & $-0,1236$ & 23 & 0,1284 & $-0,0390$ & & & \\
\hline 9 & 0,1077 & 0,1243 & 25 & $-0,0684$ & 0,1351 & & & \\
\hline 10 & 0,2507 & $-0,1070$ & & & & & & \\
\hline 11 & $-0,0161$ & 0,1566 & & & & & & \\
\hline 12 & 0,1828 & 0,2610 & & & & & & \\
\hline 13 & 0,1004 & 0,1618 & & & & & & \\
\hline
\end{tabular}




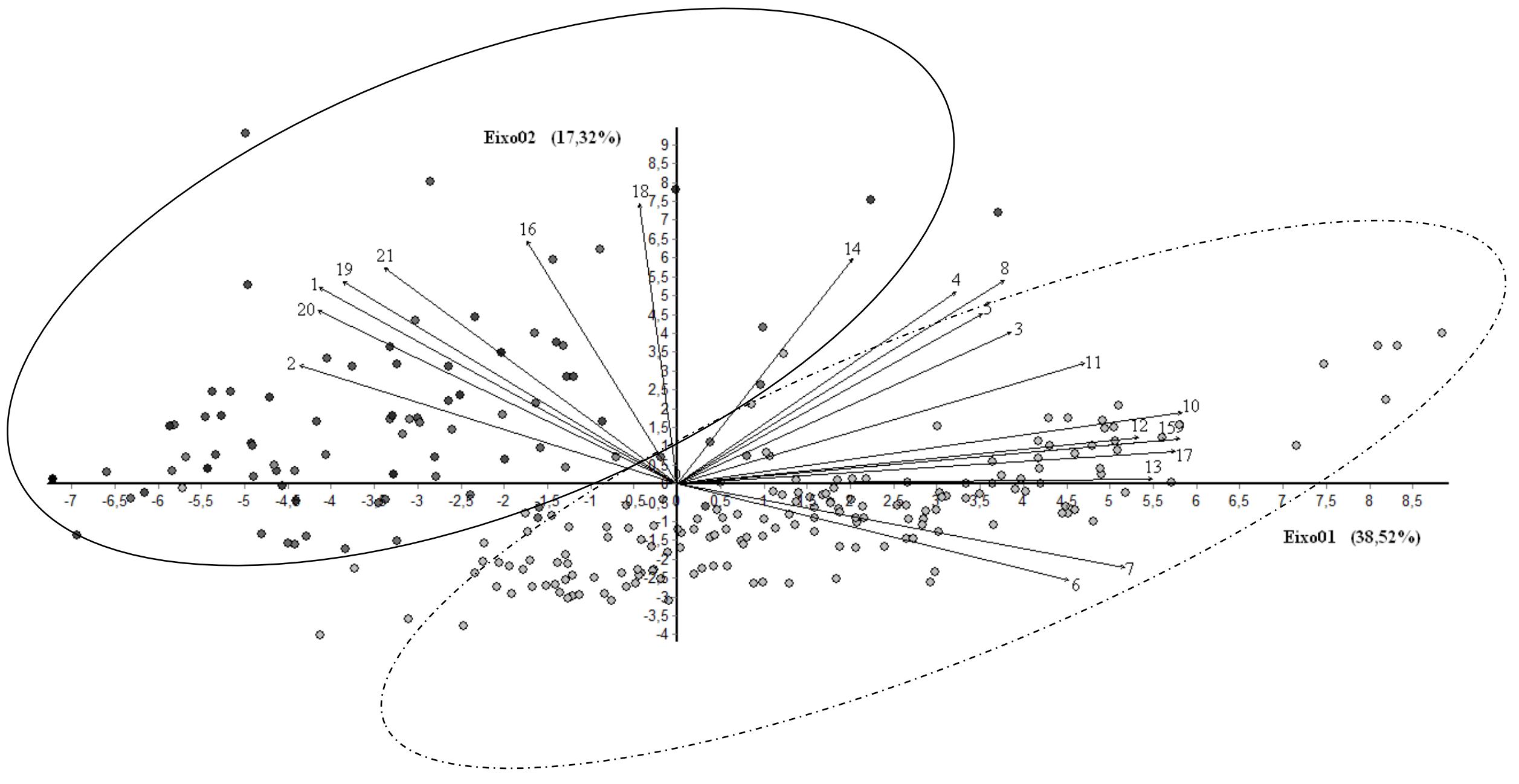

Figura 16. Análise de componente principal (PCA) usando os 28 variáveis e 253 amostras. Os círculos pretos (cultivar CD202) e cinza escuro (cultivar CD202RR) representam a câmara UV+. Os círculos em cinza claro representam as amostras provenientes das câmaras Controle e UV- de ambos os cultivares. A elipse em linha completa mostra o agrupamento dos cultivares para a câmara UV+. A elipse em linha pontilhada evidencia o agrupamento das amostras das câmaras UV- e Controle. Números para as substâncias são os mesmos utilizados na Tabela 3. 



\section{Conclusões}

Este estudo pode comprovar que existem diferenças nos conteúdos fenólicos e na biomassa de sojas quando germinadas e crescidas em maior intensidade de radiação UV (UV+).

Retornando a nossa hipótese inicial, pudemos comprovar que plantas de soja obtidas a partir da germinação sob maior intensidade de radiação UV apresentaram alteração na síntese de flavonoides especialmente das classes flavonóis e isoflavonas. Diferentemente do imaginado, nem todas as classes de flavonoides presente na constituição das folhas de soja aumentaram em conteúdo no tratamento com maior UV. Isoflavonas apresentam espectro de absorção UV-Vis com banda máxima no comprimento de onda de 260-280 nm, o que pode resultar em maior fotoproteção para plantas expostas a maiores intensidades de radiação UV.

Aumento nos conteúdos de isoflavonas acompanhados de redução nos conteúdos de flavonóis podem estar relacionados a um possível desvio de substrato da via de produção dos flavonoides, uma vez que o precursor naringenina é o mesmo na síntese de ambas as classes. Nas figuras 17 e 18, está esquematizada de forma simplificada a via de síntese de flavonoides associada aos resultados de heat map obtidos para os cultivares CD202 e CD202RR, respectivamente, mostrando a hipótese de desvio a favor da síntese de isoflavonas em detrimento da síntese de flavonóis, o que poderia significar uma vantagem para as plantas expostas a maior incidência de UV.

Trabalhos sobre a composição química de folhas de soja são escassos, uma vez que o grão é o órgão mais estudado e importante comercialmente. Dessa forma, este trabalho também vem a contribuir para o conhecimento sobre os constituintes polares presentes nas folhas de Glycine max. 


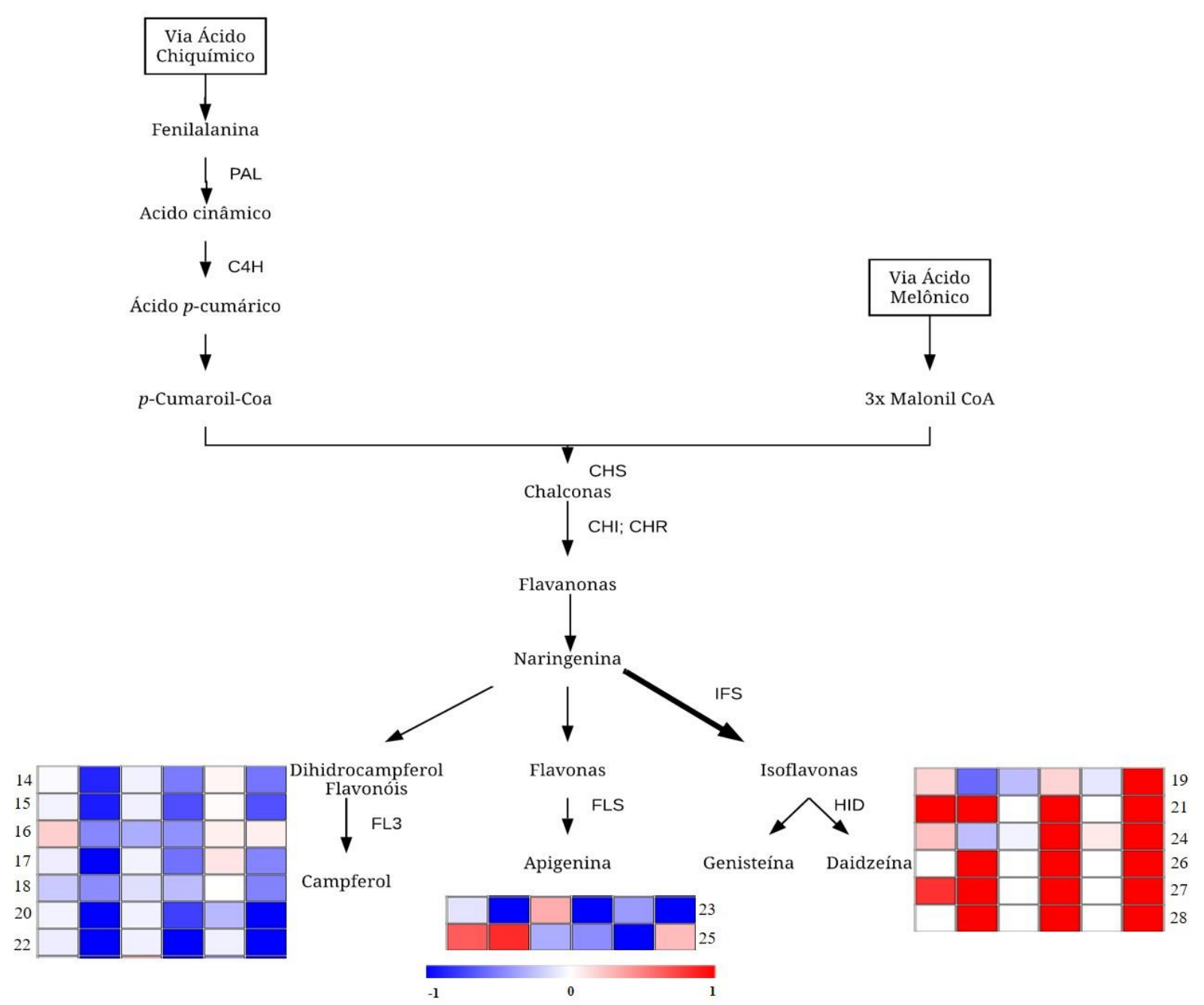

Figura 17: Esquema simplificado da via de síntese de flavonoides integrado aos resultados obtidos pela análise Heat map (figura 14) para o cultivar CD202. Enzimas: PAL: Fenilalanina amônia liase; C4H: Cinamato 4- Hidroxilase; CHS: Chalcona sintase; CHI: Chalcona isomerase; CHR: Chalcona redutase; F3H: Flavona-3-hidroxilase; FL3: Flavonol sintase; IFS: Isoflavona sintase; HID: 2-Hidroxi-isoflavona. Adaptado de DEWICK (2009) e YUK et al., 2016b. 


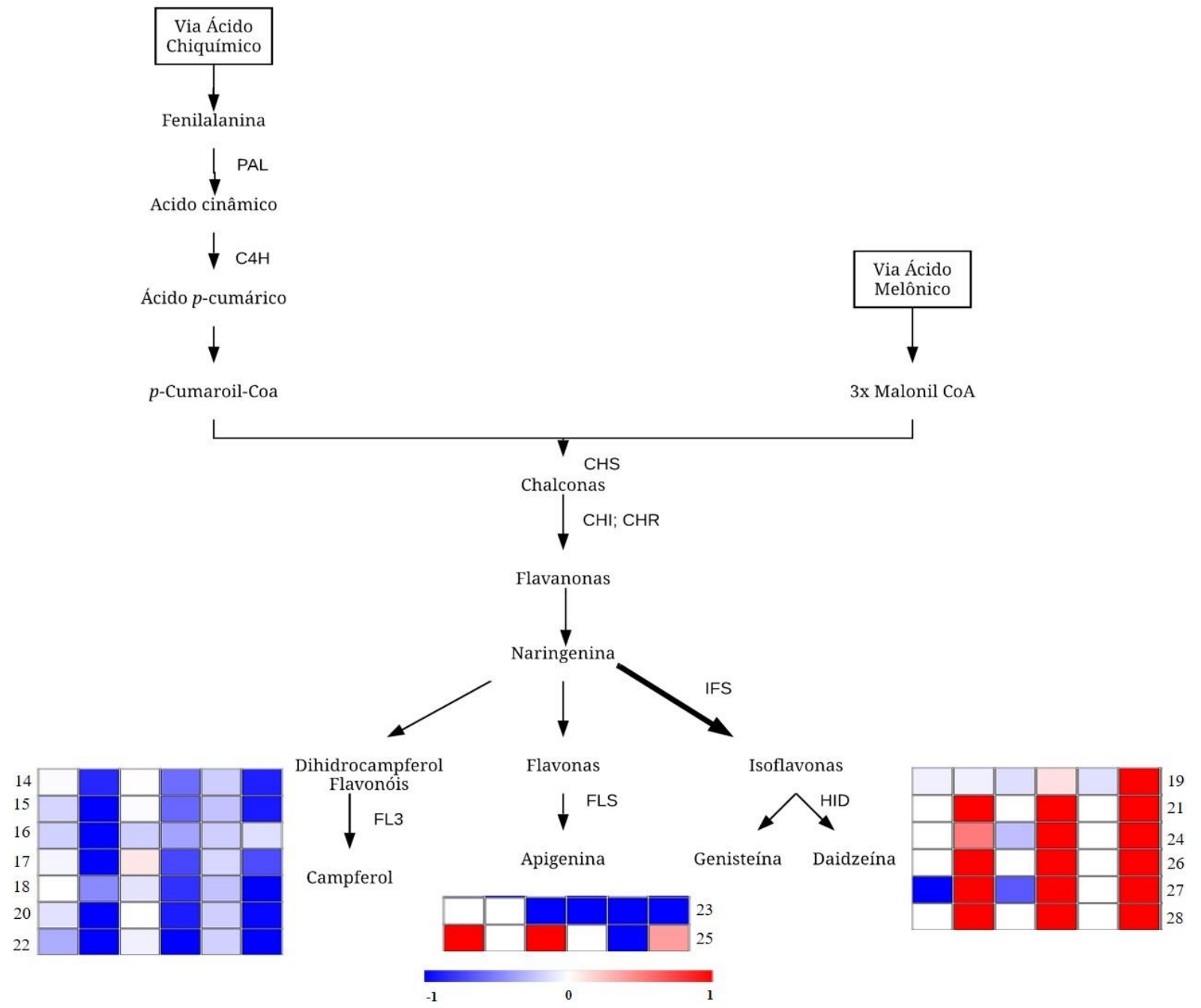

Figura 18: Esquema simplificado da via de síntese de flavonoides integrado aos resultados obtidos pela análise Heat map (figura 14) para o cultivar CD202RR. Enzimas: PAL: Fenilalanina amônia liase; C4H: Cinamato 4- Hidroxilase; CHS: Chalcona sintase; CHI: Chalcona isomerase; CHR: Chalcona redutase; F3H: Flavona-3-hidroxilase; FL3: Flavonol sintase; IFS: Isoflavona sintase; HID: 2-Hidroxi-isoflavona. Adaptado de DEWICK (2009) e YUK et al., 2016b. 



\section{Referências Bibliográficas}

AKITHA DEVI, M.K. \& GIRIDHAR, P. Variations in Physiological Response, Lipid Peroxidation, Antioxidant Enzyme Activities, Proline and Isoflavones Content in Soybean Varieties Subjected to Drought Stress. Proceedings of the National Academy of Sciences India Section B - Biological Sciences, v. 85, n. 1, p. 35-44, 2015.

ALLEN, R.G.; PEREIRA, L. S.; RAES, D.; SMITH, M. Crop evapotranspiration: Guidelines for computing crop water requirements. Rome: FAO, 1998. 300 p. (FAO - Irrigation and Drainage Paper, 56).

AL-TAWAHA, A.M., P. SEGUIN, D.L. SMITH \& BONNELL, R.B. Irrigation level affects isoflavone concentrations of early maturing soya bean cultivars. J. Agron. Crop Sci. 193, 238246. 2007.

AMAZONAS, L. Soja - Análise mensal - Conab. Conab, n. 61, p. 1-4, 2018.

ANJUM, S.; ABBASI, B.H.; DOUSSOT, J.; FAVRE-RÉGUILLON, A.; HANO, C. Effects of photoperiod regimes and ultraviolet-C radiations on biosynthesis of industrially important lignans and neolignans in cell cultures of Linum usitatissimum L. (Flax). Journal of Photochemistry and Photobiology B: Biology, v. 167, p. 216-227, 2017.

ASAO, T.; HASEGAWA, K.; SUEDA, Y.; TOMITA, K.; TANIGUCHI, K.; HOSOKI, T.; PRAMANIK, M.H.R.; MATSUI, Y. Autotoxicity of root exudates from taro. Scientia Horticulturae, v. 97, n. 3-4, p. 389-396, 2003.

Associação Brasileira de Indústria de Óleos Vegetais (ABIOVE). Disponível em: http://www.abiove.org.br/site/busca.php?tag=biodiesel. Acesso em: 31 de maio de 2018.

BALlOTTARI, M.; MOZZO, M.; GIRARDON, J.; HIENERWADEL, R.; BASSI, R. Chlorophyll triplet quenching and photoprotection in the higher plant monomeric antenna protein Lhcb5. Journal of Physical Chemistry B, v. 117, n. 38, p. 11337-11348, 2013.

BANO, C.; NIMISHA AMIST, S. \& SINGH, N.B. UV-B radiation escalate allelopathic effect of benzoic acid on Solanum lycopersicum L. Scientia Horticulturae, v. 220, n. March, p. 199205, 2017.

BARNES, P.W.; BALLARÉ, C.L. \& CALDWELL, M.M. Photomorphogenic Effects of UV-B Radiation on Plants: Consequences for Light Competition. Journal of Plant Physiology, v. 148, n. 1-2, p. 15-20, 1996.

BOEGER, M.R.T. \& POULSON, M. Efeitos da radiação ultravioleta-B sobre a morfologia foliar de Arabidopsis thaliana (L.) Heynh. (Brassicaceae). Acta Botanica Brasilica, v. 20, n. 2, 
p. 329-338, 2006.

BORNMAN, J.F.; BARNES, P.W.; ROBINSON, S.A.; BALLARÉ, C.L.; FLINT, S.D.; CALDWELL, M.M. Solar ultraviolet radiation and ozone depletion-driven climate change: effects on terrestrial ecosystems. Photochem. Photobiol. Sci., v. 14, n. 1, p. 88-107, 2015.

BUCHANAN, B.B. Biochemistry and molecular biology of plants. v. 1. p. 1689-1699. 2015.

COLLI, W. Organismos transgênicos no Brasil: regular ou desregular? Revista USP, n. 89, p. 148-173, 2011.

COMPANHIA NACIONAL DE ABASTECIMENTO. Acompanhamento da safra brasileira de grãos. Monitoramento agricola - Cultivos de verão (Safra 2015/16), v. 3, n. 1, p. 1-98, 2016. CONAB: COMPANHIA NACIONAL DE ABASTECIMENTO. Acompanhamento Da Safra Brasileira Grãos. Monitoramento agricola- Safra 2017/18, v. 5, n. 7, p. 1-139, 2018.

COODETEC. 2018.

Disponível

em: http://www.coodetec.com.br/php/detalhes_cultivar.php?id=20. Acesso em: Dezembro de 2017. CUNHA, C.P. Contribuição na investigação fitoquímica de Glycine max (soja) e Dipteryx odorata (cumaru) - otimização de análise cromatográfica e caracterização estrutural de flavonoides. Universidade Federal Rural do Rio de Janeiro, Instituto de Ciências Exatas, Programa de Pós-graduação em Química, p. 138, 2013.

DALL'AGNOL, A.; ROESSING, A.C.; LAZZAROTTO, J.J.; HIRAKURI, M.H.;OLIVEIRA, A.B. In: SARAIVA, O. F. O Agronegócio da soja no Brasil e no mundo - In: Tecnologias de Produção de Soja - Região Central do Brasil, Londrina, PR, 2008. Embrapa Soja, v. 12, n. ISSN 16778499, p. 11-27. 2008.

DE LAS FUENTES LACAVEX, G.A.; SÁNCHEZ SÁNCHEZ, A. \& CASTRO RAZCÓN, R.A. Organismos Genéticamente Modificados y Reconocimiento de Derechos Indígenas: Análisis de la Sentencia de Amparo 753/2012 Del Juzgado Segundo de Distrito en el Estado de Campeche District in the state of Campeche. Ciencia Jurídica. Departamento de Derecho. División de Derecho, Política y Gobierno, Universidad de Guanajuato, n. Año 5, num. 10, p. $87,2016$.

DEMKURA P.V. \& BALLARÉ C.L. UVR8 mediates UV-B-induced Arabidopsis defense responses against Botrytis cinerea by controlling sinapate accumulation. Molecular Plant 5, 642-652. 2012.

DHAUBHADEL S., GIJZEN M., MOY P. \& FARHANGKHOEE M. Transcriptome analysis reveals a critical role of CHS7 and CHS8 genes for isoflavonoid synthesis in soybean seeds. Plant Physiology 143, 326-338. 2007. 
DEWICK, P.M. Medicinal Natautal Products: A Biosynthetic Approach. 3rd Editio ed. United Kingdom. p. 546. 2009.

DOMINGUES, M.S. \& DAMASCENO, M. P. S. Análise da Utilização das Oleaginosas Implantação Do Programa Nacional De Produção e Uso do Biodiesel - Pnpb. Dendê , Mamona e Soja para Viabilidade de Implantação do Programa Nacional de Produção e Uso do BiodieselPnpb. p. 115, 2008.

DUKE, S.O.; RIMANDO, A.M.; PACE, P.F.; REDDY, K.N.; SMEDA, R.J. Isoflavone, glyphosate, and aminomethylphosphonic acid levels in seeds of glyphosate-treated, glyphosateresistant soybean. Journal of Agricultural and Food Chemistry, v. 51, n. 1, p. 340-344, 2003. EMBRAPA. Tecnologias da Produção de Soja - Paraná 2005. Embrapa Soja, v. 5, n. ISSN 1677-8499, p. 224, 2004.

EMBRAPA. Tecnologias de Produção de Soja - Região Central do Brasil 2014. Sistemas de Produção, p. 265, 2013.

FEHR, W. R. \& CAVINESS, C. E. Stages of Soybean Development. Special report, v. 80, n. March, p. 11, 1977.

FINCKH, M.R.; CHAVEZ, A.Q.; DAI, Q.; TENG, P.S. Effects of enhanced UV-B radiation on the growth of rice and its susceptibility to rice blast under glasshouse conditions. Agriculture, Ecosystems and Environment, v. 52, n. 2-3, p. 223-233, 1995.

FUlleR, D.Q.; ALlABY, R.G. \& STEVENS, C. Domestication as innovation: The entanglement of techniques, technology and chance in the domestication of cereal crops. World Archaeology, v. 42, n. 1, p. 13-28, 2010.

GARCILASSO, V.P.; OLIVEIRA, F.C. DE \& COELHO, S.T. Produção e Uso do Biodiesel no Brasil - Análise de Barreiras e Políticas. Anais do $\mathbf{1 0}^{\circ}$ Congresso sobre Geração Distribuída e Energia no Meio Rural, n. 11, p. 13, 2015.

HE, F.J. \& CHEN, J.Q. Consumption of soybean, soy foods, soy isoflavones and breast cancer incidence: Differences between Chinese women and women in Western countries and possible mechanisms. Food Science and Human Wellness, v. 2, n. 3-4, p. 146-161, 2013.

HO, H. M.; CHEN, R.Y.; LEUNG, L.K.; CHAN, F.L.; HUANG, Y.; CHEN, Z.Y. Difference in flavonoid and isoflavone profile between soybean and soy leaf. Biomedicine and Pharmacotherapy, v. 56, n. 6, p. 289-295, 2002.

HOLANDA, A. Biodiesel e Inclusão Social. Caderno de altos estudos, p. 26, 2004.

HOLLÓSY, F. Effects of ultraviolet radiation on plant cells. Micron, v. 33, n. 2, p. 179-197, 2002 . 
INOSTROZA-BLANCHETEAU, C.; REYES-DÍAZ, M.; ARELLANO, A.; LATSAGUE, M.; ACEVEDO, P.; LOYOLA, R.; ARCE-JOHNSON, P.; ALBERDI, M. Effects of UV-B radiation on anatomical characteristics, phenolic compounds and gene expression of the phenylpropanoid pathway in highbush blueberry leaves. Plant Physiology and Biochemistry, v. 85, 2014.

IPCC. Climate Change 2014: Synthesis Report. Contribution of Working Groups I, II and III to the Fifth Assessment Report of the Intergovernmental Panel on Climate Change. Edited by R.K. Pachauri and L. Meyer. Geneva. 151p. 2014.

JANSEN, M.A.K. Ultraviolet-B Radiation: Stressor and Regulatory Signal. In: Plant Stress Physiology. CAB Internacional. Boston, EUA. $2^{\mathrm{a}}$ edition. 2017.

KALING, M.; KANAWATI, B.; GHIRARDO, A.; ALBERT, A.; WINKLER, J.B.; HELLER, W.; BARTA, C.; LORETO, F.; SCHMITT-KOPPLIN, P.; SCHNITZLER, J.P. UV-B mediated metabolic rearrangements in poplar revealed by non-targeted metabolomics. Plant, Cell and Environment, v. 38, n. 5, p. 892-904, 2015.

KATARIA, S. \& GURUPRASAD, K. N. Solar UV-B and UV-A/B exclusion effects on intraspecific variations in crop growth and yield of wheat varieties. Field Crops Research, v. 125, p. 8-13, 2012a.

KATARIA, S.; JAJOO, A. \& GURUPRASAD, K. N. Impact of increasing Ultraviolet-B (UVB) radiation on photosynthetic processes. Journal of Photochemistry and Photobiology B: Biology, v. 137, p. 55-66, 2014b.

KIM, E. H.; RO, H.M.; KIM, S.L.; KIM, H.S.; CHUNG, I.M. Analysis of isoflavone, phenolic, soyasapogenol, and tocopherol compounds in soybean [Glycine max (L.) Merrill] germplasms of different seed weights and origins. Journal of Agricultural and Food Chemistry, v. 60, n. 23, p. 6045-6055, 2012.

KOTI, S.; REDDY, K.R.; KAKANI, V.G.; ZHAO, D.; GAO, W. Effects of carbon dioxide, temperature and ultraviolet-B radiation and their interactions on soybean (Glycine max L.) growth and development. Environmental and Experimental Botany, v. 60, n. 1, p. 1-10, 2007.

KOVACS, E. \& KERESZTES, A. Effect of gamma and UV-B/C on plant cells. Micron, v. 33, p. 199-210, 2002.

KUTCHAN, T.M. Ecological Arsenal and Developmental Dispatcher . The Paradigm of Secondary Metabolism chemicals of diverse structure players in the interaction between signal compounds involved in and evolved role in the life cycle of a. Society, v. 125, n. January, p. 5860, 2001. 
Lei $\mathrm{n}^{\mathrm{o}}$ 11.105, de 24 de Março de 2005. Disponível em: http://www.planalto.gov.br/ccivil_03/_ato2004-2006/2005/lei/111105.htm. Acesso em 05 de junho de 2018.

Lei $\mathrm{n}^{\mathrm{o}}$ 13.263, de 23 de Março de 2016. Disponível em: http://www.planalto.gov.br/ccivil_03/_ato2015-2018/2016/lei/L13263.htm. Acesso em 05 de junho de 2018.

LEE, S.J.; KIM, J.J.; MOON, H.I.; AHN, J.K.; CHUN, S.C.; JUNG, W.S.; LEE, O.K.; CHUNG, I.M. Analysis of isoflavones and phenolic compounds in Korean soybean [Glycine $\max ($ L.) Merrill] seeds of different seed weights. Journal of Agricultural and Food Chemistry, v. 56, n. 8, p. 2751-2758, 2008.

LIENER, I. E. Implications of antinutritional components in soybean foods. Critical Reviews in Food Science and Nutrition, 34(1), 31-67. 1994.

LEVETIN, E. \& MCMAHON, K. Plantas e sociedade. 5a ed. Nova York: McGraw-Hill; 2006.

LEWIS, G.; SCHRIRE, B.; MACKINDER, B. \& LOCK, M. Legumes of the World. Richmond, U.K.: Royal Botanic Gardens, Kew. 2005.

LÖFGREN, S. Solar ultraviolet radiation cataract. Experimental Eye Research, v. 156, p. 112$116,2016$.

LPWG. A new subfamily classification of the Leguminosae based on a taxonomically comprehensive phylogeny - The Legume Phylogeny Working Group (LPWG). Taxon, v. 66, n. 1, p. 44-77, 2017.

MANAVALAN, L.P. \& NGUYEN, H.T. Drought Tolerance in Crops: Physiology to Genomics. In: Plant Stress Physiology. CAB Internacional. Boston, EUA. $2^{\text {a }}$ edition. 2017.

MANNING, W.J. \& TIEDEMANN, A.V. Climate change: Potential effects of increased atmospheric Carbon dioxide $\left(\mathrm{CO}_{2}\right)$, ozone $\left(\mathrm{O}^{3}\right)$, and ultraviolet-B (UV-B) radiation on plant diseases. Environmental Pollution, v. 88, n. 2, p. 219-245, 1995.

MARKHAM, K.R. Techniques of Flavonoid Identification. Academic Press. Londres. 115p. 1982.

MARKHAM, K.R.; RYAN, K.G.; BLOOR, S.J.; MITCHELL, K.A. An increase in the luteolin: Apigenin ratio in Marchantia polymorpha on UV-B enhancement. Phytochemistry, v. 48, n. 5, p. 791-794, 1998.

MORPHEUS. Disponível em: https://software.broadinstitute.org/morpheus. Acesso em 20 de junho de 2018.

PAUL, N.D. Stratospheric ozone depletion, UV-B radiation and crop disease. Environmental 
Pollution, v. 108, n. 3, p. 343-355, 2000.

PECL, G.T.; ARAÚJO, M.B.; BELL, J.D.; BLANCHARD, J.; BONEBRAKE, T.C.; CHEN, I.C.; CLARK, T.D.; COLWELL, R.K.; DANIELSEN, F.; EVENGÅRD, B.; FALCONI, L.; FERRIER, S.; FRUSHER, S.; GARCIA, R.A.; GRIFFIS, R.B.; HOBDAY, A.J.; JANIONSCHEEPERS, C.; JARZYNA, M.A.; JENNINGS, S.; LENOIR, J.; LINNETVED, H.I.; MARTIN, V.Y.; MCCORMACK, P.C.; MCDONALD, J.; MITCHELL, N.J.; MUSTONEN, T.; PANDOLFI, J.M.; PETTORELLI, N.; POPOVA, E.; ROBINSON, S.A.; SCHEFFERS, B.R.; SHAW, J.D.; SORTE, C.J.B.; STRUGNELL, J.M.; SUNDAY, J.M.; TUANMU, M.N.; VERGÉS, A.; VILlANUEVA, C.; WERNBERG, T.; WAPSTRA, E.; WILliAMS, S.E. Biodiversity redistribution under climate change: Impacts on ecosystems and human well-being. Science, v. 355, n. 6332, 2017.

PEREIRA NETO, L.G. Germinação de sementes de soja armazenadas em bancos de germoplasma. p. 89, 2004.

PETTER, F.A.; SILVA, J.A.; ZUFFO, A.M.; ANDRADE, F.R.; PACHECO, L.P.; ALMEIDA, F.A. Elevada densidade de semeadura aumenta a produtividade da soja? Respostas da radiação fotossinteticamente ativa. Bragantia, v. 75, n. 2, p. 173-183, 2016.

Relação Nacional de Plantas Medicinais de Interesse ao Sistema Único de Saúde (RENISUS).

Disponível em: http://portalarquivos2.saude.gov.br/images/pdf/2017/junho/06/renisus.pdf. Acesso em: 26 de julho de 2018.

ROBINSON, S.A. \& ERICKSON, D.J. Not just about sunburn - the ozone hole's profound effect on climate has significant implications for Southern Hemisphere ecosystems. Global Change Biology, v. 21, n. 2, p. 515-527, 2015.

ROBINSON, S.A.; TURNBULL, J.D.; LOVELOCK, C.E. Impact of changes in natural ultraviolet radiation on pigment composition, physiological and morphological characteristics of the Antarctic moss, Grimmia antarctici. Global Change Biology, v. 11, n. 3, p. 476-489, 2005. ROGELJ, J.; DEN ELZEN, M.; HÖHNE, N.; FRANSEN, T.; FEKETE, H.; WINKLER, H.; SCHAEFFER, R.; SHA, F.; RIAHI, K.; MEINSHAUSEN, M. Paris Agreement climate proposals need a boost to keep warming well below $2{ }^{\circ}$ C. Nature, v. 534, n. 7609, p. 631-639, 2016.

SAKTHIVELU, G.; AKITHA DEVI, M. K.; GIRIDHAR, P.; RAJASEKARAN, T.; RAVISHANKAR, G. A.; NIKOLOVA, M. T.; ANGElOV, G. B.; TODOROVA, R. M.; KOSTURKOVA, G. P. Isoflavone composition, phenol content, and antioxidant activity of 
soybean seeds from India and Bulgaria. Journal of Agricultural and Food Chemistry, v. 56, n. 6, p. 2090-2095, 2008.

SALEME, M.L.S.; CESARINO, I.; VARGAS, L.; KIM, H.; VANHOLME, R.; GOEMINNE, G.; VAN ACKER, R.; FONSECA, F.C.A.; PALLIDIS, A.; VOOREND, W.; NICOMEDES, J.; PADMAKSHAN, D.; VAN DOORSSELEARE, J.; RALPH, J.; BOERJAN, W.A. Silencing CAFFEOYL SHIKIMATE ESTERASE affects lignification and improves saccharification. Plant Physiology, p. pp.00920.2017, 2017.

SANTOS, K.P.; SEDANO-PARTIDA, M.D.; MOTTA, L.B.; CORDEIRO, I.; FURLAN, C.M. Antioxidant activity of flavonoids from Croton sphaerogynus Baill. Revista Brasileira de Botanica, v. 39, n. 4, p. 1021-1030, 2016.

SAVVIDES, A.; ALI, S.; TESTER, M.; FOTOPOUlOS, V. Chemical Priming of Plants Against Multiple Abiotic Stresses: Mission Possible? Trends in Plant Science, v. 21, n. 4, p. 329-340, 2016.

SHEPHERD, G.J. FITOPAC. Versão 2.1. Campinas, SP: Departamento de Botânica, Universidade Estadual de Campinas - UNICAMP. 2010.

SHURTlEFF, W.; HUANG, H.; AOYAGI, A. History of Soybeans and Soyfoods in China and Taiwan. p. 482. 2011.

SILVA, L.R.; PEREIRA, M.J.; AZEVEDO, J.; GONÇALVES, R.F.; VALENTÃO, P.; PINHO, P.G.; ANDRADE, P.B. Glycine max (L.) Merr., Vigna radiata L. and Medicago sativa L. sprouts: A natural source of bioactive compounds. Food Research International, v. 50, n. 1, p. 167-175, 2013.

SLAVIN, M.; CHENG, Z.; LUTHER, M.; KENWORTHY, W.; YU, L. Antioxidant properties and phenolic, isoflavone, tocopherol and carotenoid composition of Maryland-grown soybean lines with altered fatty acid profiles. Food Chemistry, v. 114, n. 1, p. 20-27, 2009.

SOUZA, T.M.; SANTOS, L.E.; MOREIRA, R.R.D.; RANGEL, V.L.B.I. Avaliação da atividade fotoprotetora de Achillea millefolium L. (Asteraceae). Revista Brasileira de Farmacognosia, v. 15, n. 1, p. 36-38, 2005.

SURGET, G. STIGER-POUVREAU; V. LE LANN; K. KERVAREC; N. COUTEAU, C.; COIFFARD, L.J.M.; GAILLARD, F.; CAHIER, K.; GUÉRARD, F.; POUPART, N. Structural elucidation, in vitro antioxidant and photoprotective capacities of a purified polyphenolicenriched fraction from a saltmarsh plant. Journal of Photochemistry and Photobiology B: Biology, v. 143, p. 52-60, 2015.

TAIZ, L. \& ZEIGER, E. Fisiologia Vegetal. 4 ed. Porto Alegre: Artmed, 819p. 2009. 
TERAMURA, A.H. \& MURALI, N. S. Intraspecific differences in growth and yield of soybean exposed to ultraviolet-B radiation under greenhouse and field conditions. Environmental and Experimental Botany, v. 26, n. 1, p. 89-95, 1986.

TOPCU, Y.; DOGAN, A.; KASIMOGLU, Z.; SAHIN-NADEEM, H.; POLAT, E.; ERKAN, M. The effects of UV radiation during the vegetative period on antioxidant compounds and postharvest quality of broccoli (Brassica oleracea L.). Plant Physiology and Biochemistry, v. 93, p. 56-65, 2015.

TOZZI, A.M.G. DE A. Subfamília Papilionoideae. São Paulo. v. 8.p. 167-397. 2016.

VALDEZ SEPÚLVEDA, L.; GONZÁLEZ-MORALES, S. \& BENAVIDES, A. Ácido benzoico: biosíntesis, modificación y función en plantas. v. 6, p. 1667-1678, 2015.

VERDAGUER, D.; JANSEN, M.A.K.; LLORENS, L.; MORALES, L.O.; NEUGART, S. UVA radiation effects on higher plants: Exploring the known unknown. Plant Science, v. 255, p. 72-81, 2017.

VERNETTI JUNIOR, F. DE J. \& AGUILA, L. S. H. Avaliação de Cultivares de Soja do Grupo de Maturação 6 RR, da Rede Soja Sul de Pesquisa, na Embrapa Clima Temperado F. de J.Vernetti Junior 1 , L.S.Heiffig-del Aguila 1. Embrapa Clima Temperado, n. Pelotas, RS., p. 1161-1164, 2012.

VIDOVIĆ, M.; MORINA, F.; MILIĆ, S.; ZECHMANN, B.; ALBERT, A.; WINKLER, J.B.; JOVANOVIĆ, S.V. Ultraviolet-B component of sunlight stimulates photosynthesis and flavonoid accumulation in variegated Plectranthus coleoides leaves depending on background light. Plant, Cell and Environment, v. 38, n. 5, p. 968-979, 2015a.

VIDOVIĆ, M.; MORINA, F.; MILIĆ, S. ALBERT, A.; ZECHMANN, B.; TOSTI, T.; WINKLER, J.B.; JOVANOVIĆ, S.V. Carbon allocation from source to sink leaf tissue in relation to flavonoid biosynthesis in variegated Pelargonium zonale under UV-B radiation and high PAR intensity. Plant Physiology and Biochemistry, v. 93, p. 44-55, 2015 b.

VISNEVSCHI-NECRASOV, T.; BARREIRA, J.C.M.; CUNHA, S.C.; PEREIRA, G.; NUNES, E.; OLIVEIRA, M.B.P.P. Phylogenetic insights on the isoflavone profile variations in Fabaceae spp.: Assessment through PCA and LDA. Food Research International, v. 76, n. P1, p. 51-57, 2015.

WILLIAMSON, C.E.; ZEPP, R.G.; LUCAS, R.M.; MADRONICH, S.; AUSTIN, A.T.; BALLARE, C.L.; NORVAL, M.; SULZBERGER, B.; BAIS, A.F.; MCKENZIE, R.L.; ROBINSON, S.A.; HADER, D.P.; PAUL, N.D.; BORNMAN, J.F. Solar ultraviolet radiation in a changing climate. Nature Clim. Change, v. 4, n. 6, p. 434-441, 2014. 
XU, D.H. \& GAI, J.Y. Genetic diversity of wild and cultivated soybeans growing in China revealed by RAPD analysis. Plant Breeding, v. 122, n. 6, p. 503-506, 2003.

YAHARA, T.; JAVADI, F.; ONODA, Y.; QUEIROZ, L.P.; FAITH, D.P.; PRADO, D.E.; AKASAKA, M.; KADOYA, T.; ISHIHAMA, F.; DAVIES, S.; SLIK, J.W.F.; YI, T.; MA, K.; BIN, C.; DARNAEDI, D.; PENNINGTON, R.T.; TUDA, M.; SHIMADA, M.; ITO, M.; EGAN, A.N.; BUERKI, S.; RAES, N.; KAJITA, T.; VATANPARAST, M.; MIMURA, M.; TACHIDA, H.; IWASA, Y.; SMITH, G.F.; VICTOR, J.E.; NKONKI, T. Global legume diversity assessment: Concepts, key indicators, and strategies. Taxon, v. 62, n. 2, p. 249-266, 2013.

YUK, H.J.; LEE, J.H.; CURTIS-LONG, M.J.; LEE, J.W.; KIM, Y.S.; RYU, H.W.; PARK, C.G.; JEONG, T.S.; PARK, K.H. The most abundant polyphenol of soy leaves, coumestrol, displays potent $\alpha$-glucosidase inhibitory activity. Food Chemistry, v. 126, n. 3, p. 1057-1063, 2011a.

YUK, H.J.; SONG, Y.H.; CURTIS-LONG, M.J.; KIM, D.W.; WOO, S.G.; LEE, Y.B.; UDDIN, Z.; KIM, C.Y.; PARK, K.H. Ethylene Induced a High Accumulation of Dietary Isoflavones and Expression of Isoflavonoid Biosynthetic Genes in Soybean (Glycine max) Leaves. Journal of Agricultural and Food Chemistry, v. 64, n. 39, p. 7315-7324, 2016 b.

ZAVALA, J.A.; MAZZA, C.A.; DILLON, F.M.; CHLUDIL, H.D.; BALLARÉ, C.L. Soybean resistance to stink bugs (Nezara viridula and Piezodorus guildinii) increases with exposure to solar UV-B radiation and correlates with isoflavonoid content in pods under field conditions.

Plant, Cell and Environment, v. 38, n. 5, p. 920-928, 2015. 